\title{
Ołtarze okazjonalne wznoszone $w$ czasie procesji Bożego Ciała w kolonialnym Cusco
}

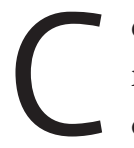

elebrowanie częstych świąt i organizowanie procesji o charakterze religijnym to zjawiska typowe dla całego świata katolickiego, a w Peru, podążającym za hiszpańskimi tradycjami, liczba dni świątecznych była i jest jeszcze bardziej znacząca. W 1819 roku Martín de Mugica, hiszpański urzędnik przebywający w Cusco, stwierdził, że w mieście więcej wypada w roku dni świątecznych niż pracujących; zgodnie z jego kalkulacją z tych pierwszych złożyć można około siedem miesięcy ${ }^{1}$. Podobnie jak w Europie, uroczystościom, zarówno religijnym, jak i świeckim, towarzyszyła architektura okazjonalna, ulice miast dekorowano tkaninami i obrazami, wznoszono łuki triumfalne i ołtarze. To, w jaki sposób w czasie procesji i świąt prezentowały się ulice Hiszpanii i miast kolonialnych, możemy dziś spróbować odtworzyć na podstawie obrazów, druków okolicznościowych, ale też zachowanych relacji i kontraktów. Przykładem może być tu drzeworyt ukazujący architekturę okazjonalną wzniesioną w Sewilli w czasie obchodów święta Matki Boskiej Niepokalanie Poczętej w 1761 roku. Ilustracji towarzyszą opisy, które ułatwiają interpretację (ilustr. 1).

Dodatkowo należy pamiętać, że wszelkie święta religijne w kolonialnym Cusco stanowiły mieszankę kulturową będącą efektem spotkania katolickich zwyczajów, zaimportowanych za sprawą Hiszpanów z Europy, z rodzimymi indiańskimi tradycjami ${ }^{3}$. Święta obchodzone w XVII i XVIII wieku możemy podzielić na jednostkowe oraz te, które obchodzono cyklicznie ${ }^{4}$. Do tych pierwszych należały beatyfikacje

\footnotetext{
CAhill 2000, s. 117.

Sanz Serrano 2007, s. 264-265; patrz także: Sanz Serrano 2008. Na ilustracji na uwagę zasługuje ołtarz znajdujący się po prawej stronie, dedykowany właśnie Inmaculacie. Wizerunek został umieszczony ponad stosem chlebów, a w opisie czytamy: Altar de la Purísima Concepción donde se repartió el pan („Ołtarz Niepokalanie Poczętej, gdzie rozdzielano chleb”).

3 Mínguez Cornelles 2003, s. 50-51 i nn.

4 Jest to tylko jeden z podziałów proponowanych przez autorkę, opisuje święta barokowe w regionie Burgos; Zaparaín Yáñez 2010, s. 347-356; patrz także: LABRAGA GARCía 2005, s. 843-846.
} 
i kanonizacje, a także ingresy, proklamacje i egzekwie. Jednymi z najlepiej udokumentowanych świąt tego rodzaju celebrowanych w Cusco były obchody beatyfikacji św. Ignacego Loyoli5, a także egzekwie po śmierci Filipa $V^{6}$. Powtarzające się święta związane były z kalendarzem liturgicznym i konkretnymi wezwaniami maryjnymi oraz chrystologicznymi, a także dedykowane świętym, niekiedy o bardzo lokalnym charakterze. Kilka z nich także doczekało się relacji i opisów, jak na przykład procesja ku czci Matki Boskiej Loretańskiej z 1692 roku7, znamy ponadto krótkie wzmianki traktujące o procesji dedykowanej Nuestra Señora de Purificación z 1608 roku$^{8}$. Wszystkim świętom celebrowanym w Cusco towarzyszyła stosowna oprawa muzyczna ${ }^{9}$, tańce ${ }^{10}$, okazjonalnie przygotowywane widowiska ${ }^{11}$, jak również sztuczne ognie ${ }^{12}$. Jedną z najważniejszych uroczystości obchodzonych w mieście (i w całym regionie andyjskim) w wiekach XVII i XVIII była procesja Bożego Ciała (Corpus Christi).

\footnotetext{
5 Relación de la Fiesta 16101923 s. 447-454; Relación de la fiesta 1610 2000, s. 156-161.

6 Santander 1748; Kubiak 2019.

7 Procesión 1692 2000, s. 161-162.

8 Amado Gonzales 2017, s. 58; AAC, Parroquia de los Naturales, Libro de Cabildo (1602-
} 1626), f. 15.

9 W wydatkach poszczególnych parafii stałym elementem są kwoty płacone muzykom, jak na przykład w parafii Belen, gdzie w spisie wydatków z 1790 roku (Libro de fabrica) odnajdujemy punkt: Iten pagué a los músicos quarto p.s para la fiesta del Corpus („Także zapłaciłem muzykom cztery peso na święto Bożego Ciała"), AAC, Cuenta de Belén (1788-1800), f. 2 r., czy też wydatkowane przez bractwo Nuestra Señora de Belén w tej samej parafii w 1792 roku, także w związku z obchodami Bożego Ciała: Ytt.p..$^{r}$ quarto p. quarto rr. que pague a los músicos Itt („Po cztery peso i reale zapłaciłem muzykom"), AAC, Cuentas de Cofradía (1788-1800), f. 4 v.

10 W 1608 roku w czasie procesji Nuestra Señora de Purificación wykonywano liczne lokalne tańce: tańce z Tomibamby czy też te nazywane taqui; patrz także: BAKer 2008, s. 61-64. W 1773 roku Alonso Carrió de la Vandera pisał o tańcach indiańskich w dniu Bożego Ciała: „tańce indiańskie, w których współzawodniczą [tancerze] ze wszystkich parafii i najbliższych okolic, są solennie przygotowywane" (las danzas de los indios, que concurren de todas las parroquias y privincias inmediatas, son muy serias en la subtancia); CARrió DE LA VANDERA 1985 [1775], s. 190. Natomiast 1834 roku José María Blanco bardziej szczegółowo pisze, że: „najpopularniejszymi tańcami Indian w czasie ich świąt, a przede wszystkim w dzień Bożego Ciała, są te, które są wykonywane przez tancerzy, chunchos, ñustas" (los bailes más comunes de los indios en sus festividades, y principalmente en el día del Corpus del Cuzco son el de los danzantes, chunchos, ñustas); Blanco 1974 [1834], s. 289.

11 BAKer 2008, s. 60-63, 78-80.

12 Ignacio de Castro cały rozdział poświęcił sztucznym ogniom. Opisuje historię ich powstania, a następnie koncentruje się na opisie sztucznych ogni w Cusco; CAstro 1978 [1787], s. 98-108. Musiały być niezwykle popularną rozrywką, skoro w 1785 roku wydano zakaz ich używania w pobliżu dawnego kolegium jezuitów, w którym urządzono magazyn prochu. W związku z tym, że kolegium znajduje się przy głównym placu miasta, zakaz obejmował także przestrzeń połowy placu przylegającego do zabudowań, również w czasie świąt; ARC, Intendencia, Real Hacienda, Legajo 171. 


\section{Stan badań i źródła}

Architektura okazjonalna ${ }^{13} \mathrm{w}$ Cusco nie była dotąd poddawana oddzielnej analizie. Graciela María Viñuales w swojej książce poświęconej przestrzeni miejskiej kolonialnego miasta jeden $\mathrm{z}$ krótkich podrozdziałów zatytułowała La arquitectura efímera ${ }^{14}$, ale jest to jedynie pięciostronicowy przegląd konstrukcji, które powstawały z okazji świąt celebrowanych w mieście, zarówno tych o charakterze świeckim, jak i religijnym ${ }^{15}$. Przy okazji analizy obchodów najważniejszych uroczystości religijnych w Cusco, takich jak święta Bożego Ciała (Corpus Christi) czy procesja Chrystusa od Trzęsień Ziemi (Señor de los Temblores), wielu autorów poświęca częściowo swoje rozważania sztuce efemerycznej towarzyszącej procesjom. Na uwagę zasługują książki Carolyn Dean ${ }^{16} \mathrm{i}$ Jorge’a Bernalesa Ballesterosa ${ }^{17}$ dotyczące różnych aspektów obchodów Bożego Ciała, a także zbiorowe opracowanie autorstwa Jorge’a Floresa Ochoy, Elizabeth Kuon Arce, Roberta Samaneza Argumedo ${ }^{18}$ i publikacja Ángeli Brachetti ${ }^{19}$ poświęcone kuzkeńskim fiestom.

Najważniejszymi źródłami, które pozwalają na badanie architektury okazjonalnej w Cusco, są dzieła malarskie z epoki, zachowane dokumenty archiwalne oraz kroniki. Wśród obrazów najbardziej pomocna jest słynna seria malarska ukazująca procesję Bożego Ciała. (ilustr. 2-3) Jest to cykl namalowany, jak się przyjmuje, w ostatniej ćwierci XVII wieku, za czym przemawia analiza przedstawionych postaci oraz wzmianki w dokumentach archiwalnych ${ }^{20}$. Autorstwo obrazów trudne jest do

\footnotetext{
13 W kręgu badań hiszpańskojęzycznych konstrukcje architektoniczne wznoszone w czasie świąt, ze względu na krótki czas ich istnienia, określane są mianem „architektury efemerycznej” (arquitectura efímera). Jak się przyjmuje, pojęcie to zostało wprowadzone przez Yvesa Bottineau'a w 1968 roku; BotтinEAU 1968, s. 23-30. Rafael Ramos zaznacza, że obok wymienionego terminu używa się także innych: fábricas provisionales, arquitectura decorativa czy - tak jak w języku polskim - arquitectura ocasional; RAMos SosA 1992, s. 21. Do najbardziej znanych publikacji, w których autorzy podejmują ogólne zagadnienia związane z problematyką świąt i dzieł sztuki o charakterze efemerycznym w Hiszpanii i jej koloniach w okresie baroku, należą książki i artykuły Antonia Boneta Correi (Bonet Correa 1990, 1993) i Fernanda Moreny Cuadry (MorenA CuAdro 1985, 1989). W artykule stosowane są wymiennie określenia charakterystyczne dla Hiszpanii i Hispanoameryki (architektura efemeryczna, sztuka efemeryczna) oraz typowe dla polskiej literatury przedmiotu (architektura okazjonalna).

14 Viñuales 2004, s. 49-55.

15 Zagadnienie obchodów pogrzebowych i związanych z nimi dekoracji o charakterze artystycznym podejmują Carmen Ruiz Pardo, José R. Jouve Martín, Ewa Kubiak; Ruiz Pardo 2008, s. 67-68; Jouve Martín 2014, s. 229-232; Kubiak 2019.

16 DEAN 2002 [1999].

17 Bernales Ballesteros 1996.

18 Flores Ochoa, Kuon Arce, Samanez Argumedo 2009.

19 Książka ukazała się dwukrotnie: w roku 2005 oraz poszerzona wersja w roku 2014. Jednak zagadnienia związane z okresem kolonialnym zostały powtórzone prawie bez zmian w obu publikacjach; Brachetti 2005, Brachetti-Tschohl 2014.

20 Mariátegui Oliva 1951, s. 21-23; Mesa, Gisbert 1982, s. 160-180; Dean 2002 [1999], s. $61-63,86$.
} 


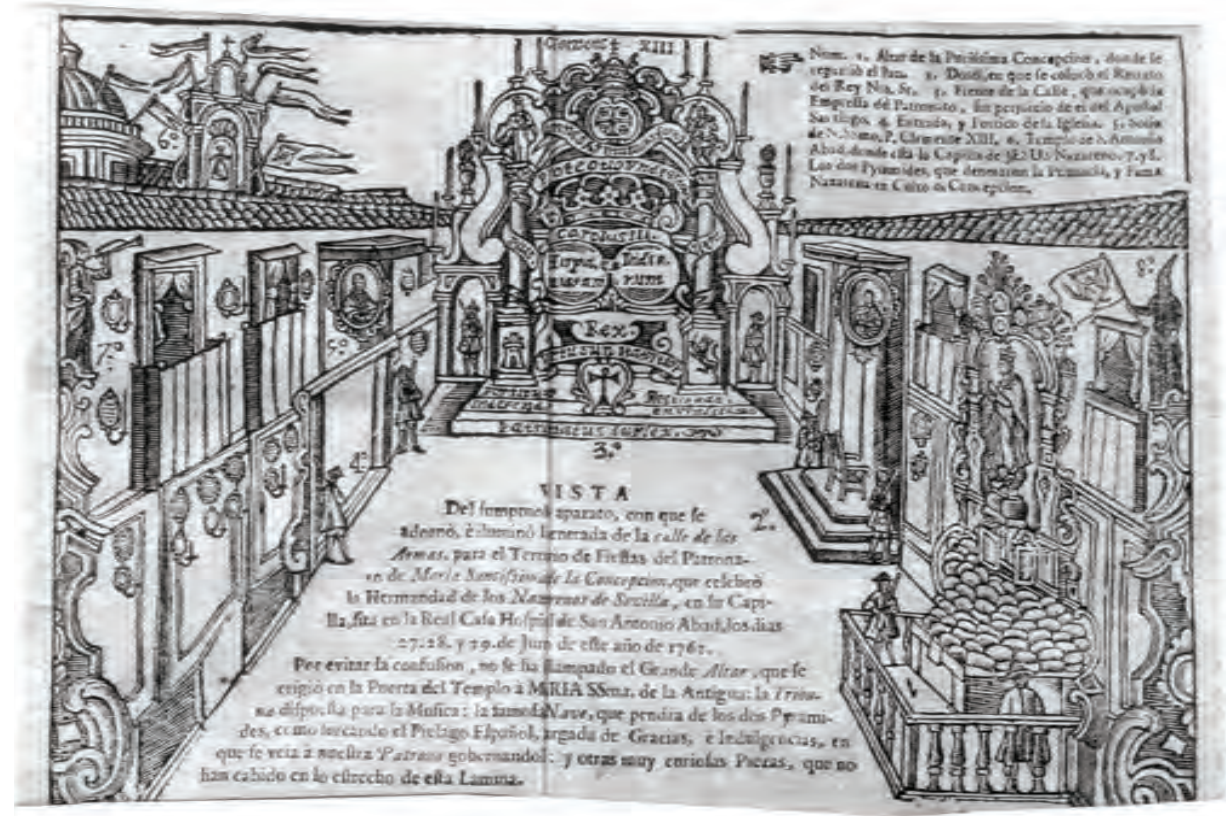

1. Architektura okazjonalna w czasie święta Niepokalanie Poczętej z 1761 r., grafika z publikacji Jacinto Núñeza, Astronomía Mariana, con la que la siempre ilustre, y venerable Hermandad de Jesús Nazareno, y Santísima Cruz de Jerusalén, la Real Casa Hospital de San Antonio Abad de esta ciudad de Sevilla [...] en los días 27, 28 y 29 de junio de este año de 1761, Sevilla [bez roku wydania]; SANZ SERRANO 2007, s. 265

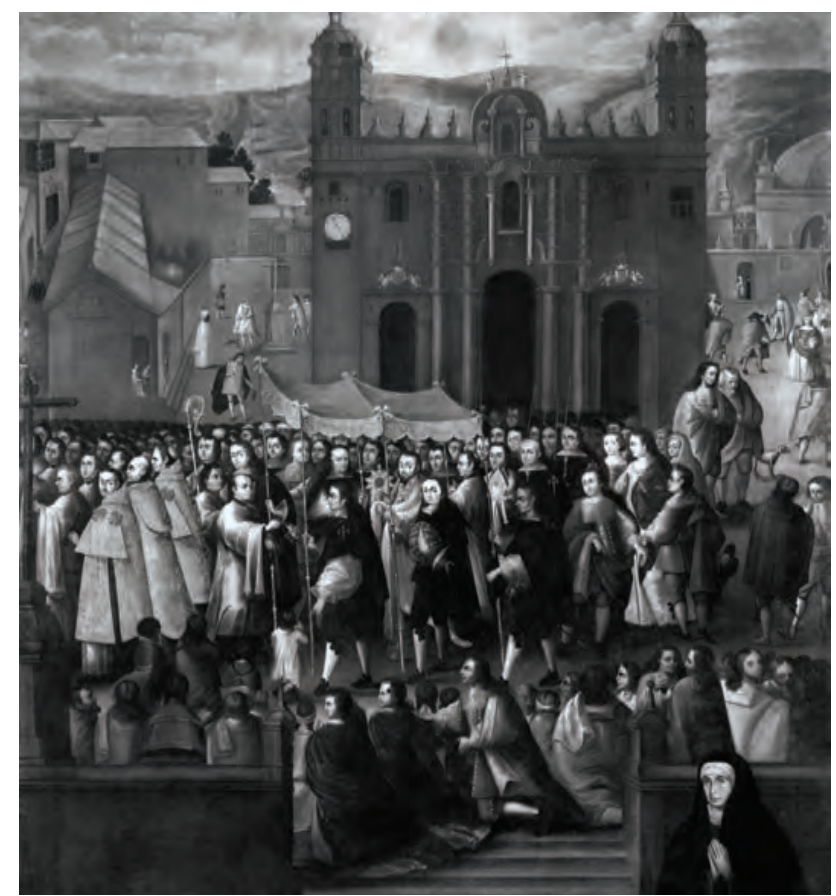

2. Wyjście procesji Bożego Ciała, albo Biskup Manuel de Mollinedo y Angulo opuszczający katedrę, cykl malarski Corpus Christi, ok. 1675-1680, olej na płótnie, Museo de Arte Religioso, Cusco, Peru, fot. E. Kubiak 


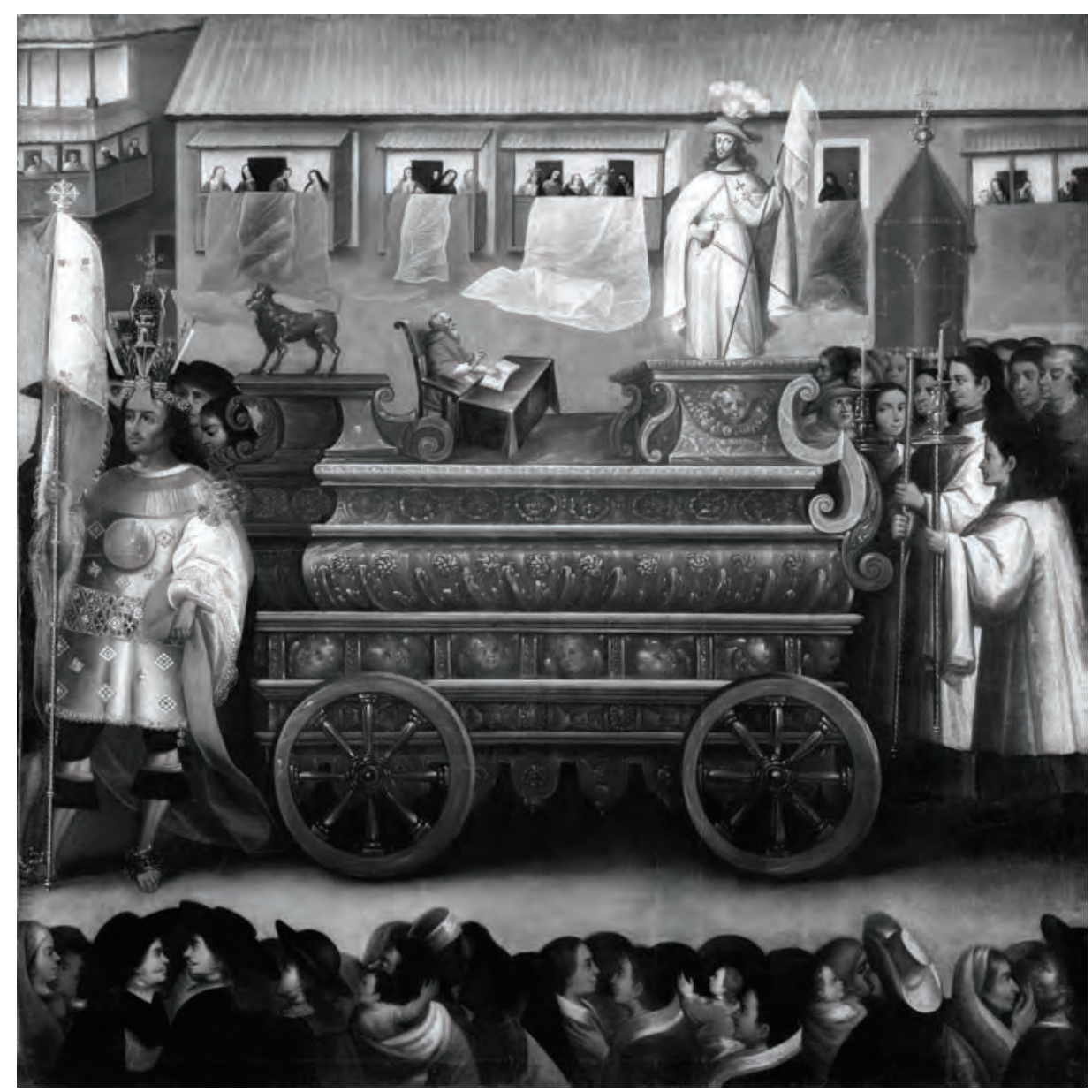

3. Parafia św. Jakuba (Santiago), cykl malarski Corpus Christi, ok. 1675-1680, olej na płótnie, Museo de Arte Religioso, Cusco, Peru, fot. E. Kubiak

jednoznacznego określenia i na podstawie analizy stylistycznej większość badaczy jest zgodnych co do istnienia przynajmniej dwóch artystów malarzy lub nawet warsztatów, w orbicie których powstały opisywane dzieła. W tym okresie najważniejszymi artystami działającymi w Cusco byli Diego Quispe Tito oraz Basilio Pacheco de Santa Cruz Pumacallao; zdania co do dominacji wpływów któregoś z nich są wśród autorów podzielone ${ }^{21}$. Cykl malarski stanowił dekorację kościoła Santa Ana w $\mathrm{Cusco}^{22}$

21 Teresa Gisbert odnajduje stylistyczne odniesienia do prac Diego Quispe Tito, GisBert 1983, s. 159. Natomiast Ricardo Mariátegui Oliva i Jorge Bernales Ballesteros widzą większą zależność od prac Basilio de Santa Cruz Pumacallao; Mariategui Oliva 1983, s. 17, 19; Bernales BalleSTEROS 1987, s. 332; DeAn 2002 [1999], s. 63.

22 Na temat cyklu malarskiego jako pierwszy pisał José Uriel García i chociaż tekst znajduje się w przewodniku po Cusco, możemy potraktować go jako pierwszą próbę analizy zespołu malarskiego; García 1922, s. 214-218. 
TECHNE

T E X N H

SERIA NOWA

i znajdował się tam do $1968 \mathrm{roku}^{23}$, a następnie przeniesiono go do Muzeum Sztuki Religijnej (Museo de Arte Religioso) w Cusco ${ }^{24}$. Obrazy zawsze wzbudzały zainteresowanie odwiedzających $\mathrm{Cusco}^{25}$ i poczucie dumy jego mieszkańców ${ }^{26}$.

Większość kontraktów zawieranych pomiędzy fundatorami i wykonawcami dotyczących wykonania sztuki kolonialnej w Cusco i regionie znamy dzięki poszukiwaniom Jorge’a Cornejo Bouroncle’a, który był pierwszym dyrektorem powstałego w 1949 roku archiwum historycznego w Cusco (Archivo Histórico del Cuzco) ${ }^{27}$, dzieląc prace nad organizacją tej instytucji z badaniami naukowymi i analizowaniem zawartości zbiorów. Jednym z efektów tych działań, bardzo ważnym dla historyków sztuki, była seria sześciu artykułów wydanych w lokalnym czasopiśmie „Revista del Archivo Historico del Cuzco" w latach 1951-1958, gdzie Bouroncle spisał odnalezione kontrakty dotyczące wszelkich obiektów artystycznych okresu kolonialnego, między innymi te odnoszące się do architektury okazjonalnej ${ }^{28}$ (ilustr. 4). Następnie publikacja ta ukazała się w 1960 roku w formie książki pt. Derroteros de arte cuzque$\tilde{n} o^{29}$, która została wykorzystana w niniejszym opracowaniu. Pomocne okazały się także zachowane $\mathrm{w}$ archiwum arcybiskupim inwentarze kościołów, księgi budowy świątyń (libros de fabrica) oraz dokumenty dotyczące bractw religijnych działających przy kościołach w Cusco.

Pierwszą kroniką, która daje nam wyobrażenie życia, zwyczajów oraz religijności w początkowym okresie kolonii, jest praca Inki Garcilaso de la Vegi. W niej znalazły się również opisy świąt, na przykład pierwsze obchody Bożego Ciała

\footnotetext{
23 Część obrazów przed tą datą znalazło się w nieznanych okolicznościach w kolekcji prywatnej w Chile. Na temat tej części cyklu malarskiego patrz: Mariategui Oliva 1954.

24 W muzeum w Cusco znajduje się 12 płócien.

25 W 1834 roku José María Blanco podróżował jako towarzysz nowego prezydenta Luisa José de Obregoso y Moncada po południowym Peru. Jednym z zajważniejszych punktów podróży były odwiedziny Cuzco. W swojej relacji opisał większość budynków miasta, między innymi także znajdujący się tam kościół św. Anny i stwierdził, że: „największą jego drogocennością są ogromne obrazy delikatnego pędzla, które po obu stronach wzdłuż kościoła umieszczono w bogatych ramach. Na nich przedstawia się procesję Bożego Ciała, która dawniej odbywała się w Cusco i w czasie której paradowano w strojach używanych przez Indian i Indianki szlachetnego pochodzenia, niosąc swoje sztandary, a także przedstawia się tam zachowane przez nich zwyczaje i pochodzenie" (Las mejores alhajas que tiene son los cuadros, que al un lado y otro del cañón del templo están enclavados en la pared en ricos marcos dorados, que son de un pincel delicado. En ellos se representa la procesión del Corpus que antiguamente se hacía en el Cuzco, en la que se manifiestan los vestidos y galas que usaban los indios e indias nobles llevando sus estandartes, y las costumbres y procedencia que guardaban); BLANCO 1974 [1834], s. 220.

26 W XIX-wiecznym inwentarzu kościoła św. Anny (1836) tylko niektóre obrazy zostały dookreślone wezwaniem. Obok serii z życia patronki kościoła (en el cuerpo de iglesia diez y seis lienzos de la vida de mis Srã Stã Ana con sus marquezias y coronación dorado) wyróżniona bardziej precyzyjną wzmianką została tylko seria ukazująca procesję Bożego Ciała (Diez y ocho lienzos dela proces. ${ }^{n}$ de Corpus con sus chorcholas doradas); AAC, Fabrica e inventario, Iglesia de Santa Ana, 1836-1874.

27 Obecnie archiwum nosi nazwę Archivo Regional del Cusco.

28 Niestety nie wszystkie dokumenty odnotowane przez Cornejo Bouroncle’a można dziś odnaleźć $\mathrm{w}$ archiwum. Z większością można się jednak zapoznać bezpośrednio.

29 Cornejo Bouroncle 1960.
} 


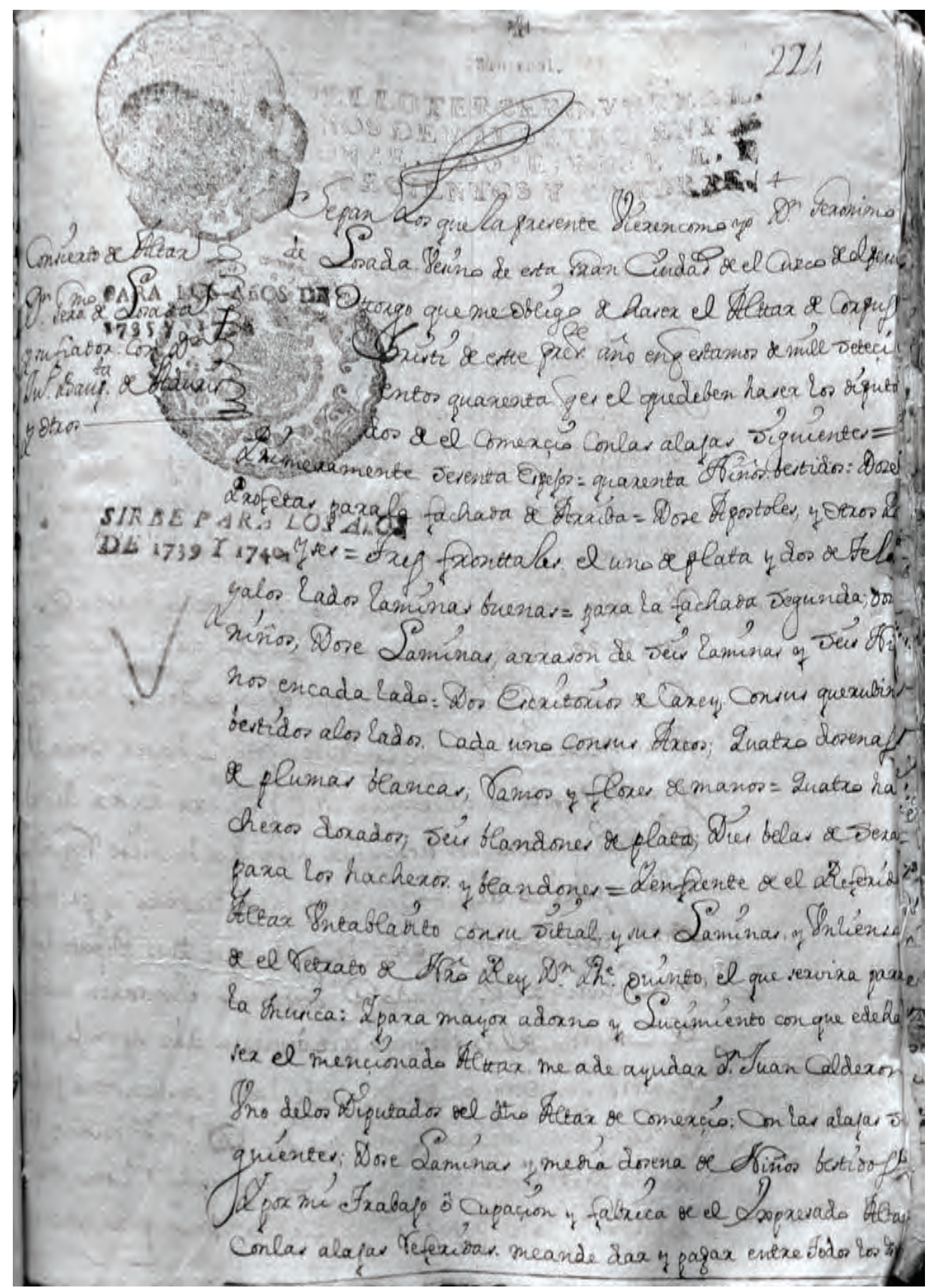

4. Pierwsza strona umowy z 1740 roku pomiędzy Gerónimem de Lozadą i przedstawicielami cechu handlowego na wykonanie ołtarza na procesje Bożego Ciała; ARC, Sección Notarial, Ambrosio Aria de Lira, (25), f. 224 r 
TECHNE

T E X N H

SERIA NOWA

z 1555 roku $^{30}$. Kolejną - a w moim przekonaniu najważniejszą - kroniką dla badacza okresu kolonii, która pozwala na poznanie życia kuzkeńczyków, jest relacja spisana w połowie XVIII wieku przez Diego de Esquivela y Navię ${ }^{31}$. Pozostałe kroniki (na przykład autorstwa Alonsa Carrió de la Vendery, Ignacia de Castro czy José Maríi Blanco) $)^{32}$, a także opisy i listy mają charakter uzupełniający. Wreszcie jako materiał porównawczy posłużyć mogła XVII-wieczna kronika opisująca dzieje innego andyjskiego miasta Peru: Potosi. Jest to słynna Historia de la Villa Imperial de Potosí pióra Bartoloméa Arzánsa Orsúi y Veli³3.

\section{Corpus Christi. Obchody Bożego Ciała w kolonialnym Cusco}

Ustanowienie święta Bożego Ciała wynikało z potrzeby otaczania kultem realnie obecnego w Eucharystii ciała Chrystusa. Było efektem formowania się kalendarza liturgicznego i ostatecznie zostało zatwierdzone przez Urbana IV w bulli Transiturus de hoc mundo 11 sierpnia 1264 roku $^{34}$. Następnie, na początku XIV wieku, Klemens V nakazał celebrowanie święta w całym kościele katolickim, wpisując je w poczet świąt o najwyższej randze i od tego momentu datuje się obchody Bożego Ciała w formie procesji ${ }^{35}$, jednak dopiero jego następca Jan XXII w 1317 roku potwierdził oficjalnie procesjonalną formę obchodów Bożego Ciała, nakazując celebrowanie go w każdej parafii ${ }^{36}$. Pierwsza hiszpańska relacja dotycząca procesji Bożego Ciała pochodzi z początków XIV wieku. W 1317 roku w Pampelunie bractwo Najświętszego Sakramentu celebrowało święto na ulicach miasta, a w czasie procesji odnotowano obecność wozów procesyjnych (carros triunfales). Kolejne udokumentowane procesje odbyły się w Calahorze i León (1318), Geronie (1319), Barcelonie (1322), Ricli (1328), Vich (1330), Leridzie (1344) i w Walencji (1355) ${ }^{37}$. Pierwsze wzmianki na temat obchodów procesji Bożego Ciała w Sewilli datuje się na lata 1426 i 1430, jednak bardziej szczegółowa relacja pochodzi 1454 roku ${ }^{38}$.

W Ameryce Łacińskiej na ukształtowanie się form kultu religii chrześcijańskiej ogromny wpływ miały niewątpliwie zwyczaje praktykowane na terenie Hiszpanii, a szczególnie Andaluzji. Procesje stały się w Ameryce jednymi z ważniejszych sposobów celebrowania obchodów religijnych, w niektórych parafiach kultywowano

\footnotetext{
30 Garcilaso de Vega 1944 [1617], s. 184-186.

31 Esquivel y NaVia 1980 [c. 1749].

32 Carrió de la Vendera 1985 [1775]; Castro 1978 [1787]; Blanco 1874 [1834].

33 Arznás Orsúa y Vela 2012 [1965], vol. 1-3. José de Mesa i Teresa Gisbert jako pierwsi krótko omówili opisy dzieł sztuki i relacje związane z zbytkami i świętami w kronice potosińskiej; Mesa, Gisbert 2012 [1965], s. 439-460.

34 Lleo Cañal 1975, s. 3; Vizuete Mendoza 2002, s. 19.

35 Jedna z pierwszych udokumentowanych procesji Bożego Ciała odbyła się w Awinionie w 1314 roku, na podobny czas datuje się pierwsze procesje w Katalonii; Vizuete Mendoza 2002, s. 32-33.

36 Lleo Cañal 1975, s. 4; Vizuete Mendoza 2002, s. 33.

37 Vizuete Mendoza 2002, s. 33.

38 Lleo Cañal 1975, s. 4.
} 
je w każdą niedzielę, ale najbardziej okazałe miały miejsce w czasie Wielkiego Tygodnia i święta Corpus Christi ${ }^{39}$. Od początku ewangelizacji rozbudowany kult sprawowany podczas dnia Bożego Ciała zyskał w Ameryce bardzo dużą popularność. Pierwsza udokumentowana procesja w Nowym Świecie odbyła się w mieście Meksyku w 1526 roku $^{40}$.

Także w Cusco Boże Ciało było i nadal jest jednym z najważniejszych świąt w roku liturgicznym. Po raz pierwszy, zgodnie z relacją Inki Garcilaso de la Vegi, było celebrowane w 1555 roku $^{41}$. W opisie zatytułowanym Jak celebrowali Indianie i Hiszpanie święto Najświętszego Sakramentu w Cuzco (Cómo celebravan los indios y españoles la fiesta de Santíssimo Sacramento en el Cozco) można znaleźć kilka wzmianek dotyczących dekoracji miasta i obiektów artystycznych towarzyszących procesji, całość opisu dotyczy jednak w znacznym stopniu tego, jak zostały przekształcone zwyczaje Indian w nowej rzeczywistości, w której znaleźli się rdzenni mieszkańcy Andów poddani procesowi ewangelizacji po hiszpańskim podboju.

Bardzo ważnym momentem było uwzględnienie święta Bożego Ciała w Ordynacjach wicekróla Toledo ${ }^{42}$ dla miasta Cuzco (Ordenanzas del virrey Toledo para la ciudad del Cuzco) z 1572 roku$^{43}$. Zapisano tam, że Corpus Christi jest najważniejszym świętem w roku liturgicznym. Dzień świąteczny miała poprzedzać wieczorna msza. Na trasie procesji przykazano ozdobić ulice. Wszystkie bractwa i cechy zostały zobowiązane do odpowiedniego przygotowania się i zaprezentowania jednego tańca. Ponad monstrancją niesioną $\mathrm{w}$ czasie procesji powinno znajdować się palium. Pochód miał rozpoczynać corregidor ${ }^{44}$ niosący sztandar z Najświętszym Sakramentem, a za nim podążali podtrzymujący baldachim alcalde (burmistrz) i radni, następnie pozostali urzędnicy, sędzia Indian, główny prokurator i pisarz miejski ${ }^{45}$. Także przedstawiciele wszystkich parafii indiańskich mieli swoje powinności, będąc zobowiązanymi do zaprezentowania dwóch lub trzech tańców ${ }^{46}$, odpowiedniego

39 LABArga García 2005, s. 801.

40 Tamże, s. 840; opisy pierwszych procesji pozostawili Fray Toribio de Benavante oraz Juan de Torquemada; Buelna SERrano 2002, s. 285-287.

41 Garcilaso de la VEgA 1944 [1617], s. 184-186.

42 Francisco de Toledo był wicekrólem Peru w latach 1569-1581. Za jego rządów przeprowadzono reformy zarówno ekonomiczne, jak i społeczne, które można potraktować jako kluczowy moment w procesie kształtowania się systemu kolonialnego; Kubiak 2015, s. 82-83; PiEtraszczyk-SęKowska 2015, s. 53; Hidalgo Nuchera 2012, s. 460-463; Roel Pineda 1999, s. 97-98.

43 TOLEdo 1924.

44 Corregidor jest funkcją urzędniczą, charakterystyczną dla Hiszpanii i jej kolonii, która w Peru wprowadzona została w 1560 roku. Człowiek nominowany na to stanowisko sprawował w imieniu króla władzę administracyjną i sądowniczą w mieście lub całym regionie, a w realiach kolonialnych miał też za zadanie czuwać nad złagodzeniem wyzysku wobec ludności tubylczej; PIETrAszCZyK-SęKowska 2015, s. 45; Hidalgo Nuchera 2012, s. 454-456; Roel Pineda 1999, s. 89-94.

45 Toledo 1924, s. 87-90.

46 W czasie Bożego Ciała każda z parafii kuzkeńskich otrzymywała pozwolenie na wykonanie dwóch lub trzech tańców; Amado Gonzales 2017, s. 58-60. 
TECHNE

T E X N H

SERIA NOWA

przystrojenia ulic na trasie przemarszu oraz przygotowania andas ${ }^{47}$ dla świętego wizerunku reprezentującego parafię $\mathrm{w}$ czasie procesji ${ }^{48}$. W stosownym udekorowaniu miasta mieli ponadto pomagać Indianie cañares i chachapoyas, którzy pełnili służbę porządkową i pomocniczą w czasie wszystkich świą ${ }^{49}$.

Tradycja wystawnego celebrowania procesji Bożego Ciała w Cusco zakorzeniła się w społeczności miasta. Obchody przybierały niezwykle barwną, rozbudowaną formę, co oczywiście odzwierciedlało się także w uświetniających procesję obiektach architektury efemerycznej.

\section{Altares efimeras. Architektura okazjonalna $w$ czasie procesji Bożego Ciała}

Siedemnastowieczne ołtarze wznoszone z okazji obchodów Bożego Ciała w Cusco znamy przede wszystkim ze wspomnianego cyklu obrazów prezentujących procesję, czyli można uznać, że ilustrują dekoracje powstające w ostatniej ćwierci XVII wieku. Niektóre płótna ukazują tylko figury procesyjne umieszczone na wozach, inne jednak przedstawiają rzeźby świętych ustawione na andas i niesione przez cargadores, w głębi zaś widać ołtarze oraz łuki triumfalne, które uświetniały religijny pochód. Główne przedstawienia ołtarzy odwołują się do znanych kompozycji malarskich i motywów, popularnych w kręgu sztuki kuzkeńskiej. Są to Matka Boska Niepokalanie Poczęta, adoracja Eucharystii i Ostatnia Wieczerza, Ukrzyżowanie, Eucharystia, obrona Eucharystii, scena Przemienienia Pańskiego oraz wizerunek Dzieciątka Jezus. Dominujący wątek ikonograficzny zaprezentowany na ołtarzach jest związany z ustanowieniem, kultem i triumfem Najświętszego Sakramentu. Carolyn Dean widzi w tym cyklu malarskim manifestację polityki ewangelizacyjnej biskupa Manuela de Mollinedo y Angulo ${ }^{50}$.

Ołtarz Matki Boskiej Niepokalanie Poczętej (ilustr. 5) został zadedykowany najprawdopodobniej miejscowemu wizerunkowi. Na szczycie ołtarza umieszczono figurę Matki Boskiej. Jorge Bernales Ballesteros zastanawia się, czy jest to postać Asunty, patronki katedry, czy też wizerunek określany jako La Linda (Piękna) ${ }^{51}$, czyli figura maryjna otaczana do dziś kultem w katedrze kuzkeńskiej (ilustr. 6); Ricardo

\footnotetext{
47 Andas - tym terminem w Cusco określa się podstawę procesyjnego feretronu przeznaczoną do ustawienia figury w celu transportu w czasie procesji. Tablero que, sostenido por dos varas paralelas y horizontales, sirve para conducir efigies, personas o cosas lub Féretro o caja con varas, en que se llevan a enterrar los muertos, (DRAE, hasło: andas). W Andaluzji używa się określenia paso.

48 Toledo 1924, s. 201.

49 Tamże, s. 193.

50 Dean 2002 [1999], s. 88-97; Manuel de Mollinedo y Angulo przed objęciem biskupstwa w Cusco sprawował funkcję proboszcza parafii Nuestra Señora de Almudena w Madrycie. Po nominacji na stanowisko przybył do Cusco w 1673 roku i sprawował funkcję biskupa do śmierci w 1699 roku. Z jego osobą łączy się intensyfikację działań artystycznych i dopełnienie wystroju wnętrz kościołów odbudowywanych w drugiej połowie XVII wieku po rujnującym miasto trzęsieniu ziemi z 1650 roku; Chacón Pumacahua 2015, s. 50-55.

51 Bernales Ballesteros 1996, s. 22.
} 
$71 \mid \begin{aligned} & \text { TECHNE } \\ & \text { TEX N H } \\ & \text { SERIA NOWA }\end{aligned}$

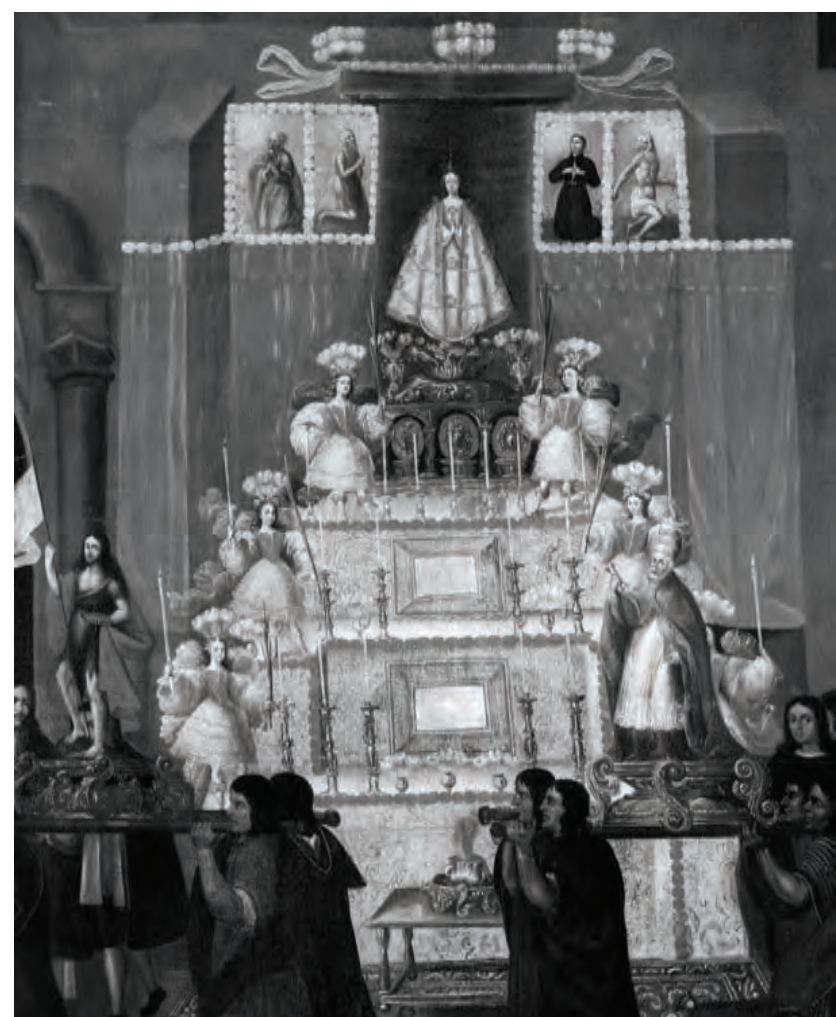

5. Ołtarz Matki Boskiej Niepokalanie Poczętej na obrazie z przedstawieniem bractw Św. Juana Chrzciciela i św. Piotra, cykl malarski Corpus Christi, ok. 1675-1680, olej na płótnie, Museo de Arte Religioso, Cusco, Peru, fot. E. Kubiak

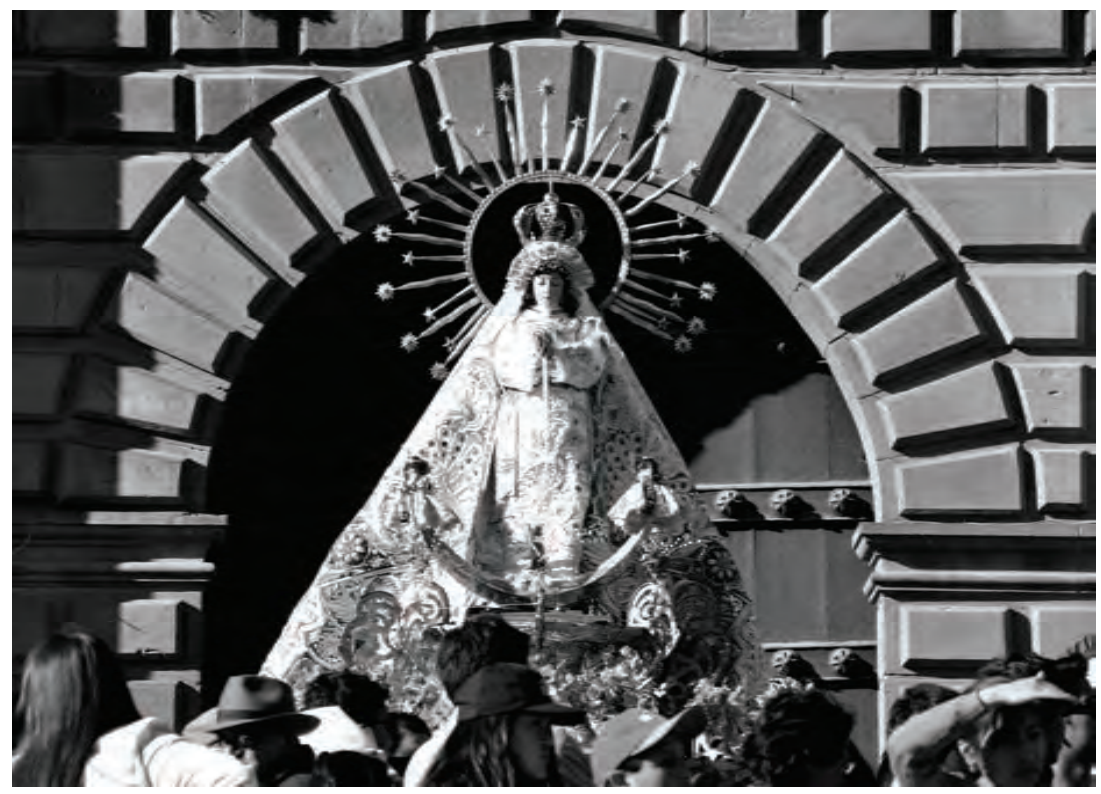

6. La Linda, Matka Boska Niepokalanie Poczęta, rzeźba anonimowa, pierwsza połowa XVII wieku, w czasie procesji Bożego Ciała w 2013 roku, Cusco, Peru, fot. E. Kubiak 
TECHNE

T E X N H

SERIA NOWA

Mariátegui Oliva przychyla się do tej drugiej koncepcji ${ }^{52}$. Ołtarz ma formę piramidy. Trzy dolne platformy pokryte zostały pasteloworóżową tkaniną, stoją na nich trzy pary aniołów: czterej ze świecami i palmami w dłoniach, dwaj tylko z palmami. Poza tym ołtarz zdobi dziesięć większych świeczników i siedem mniejszych oraz pięć wazoników z bukietami z piór. Figura Matki Boskiej umieszczona została na drewnianym postumencie ozdobionym trzema arkadkami z dekoracyjnymi medalionami. Figura wydaje się wyrastać z kępy stylizowanych liści. W tle znajduje się czerwona tkanina. Po bokach rzeźby stoją dwa wazony z bukietami białych piór. Postać Matki Boskiej wraz ze strojem zamyka się trójkącie ograniczonym na dole półksiężycem. Maria ubrana jest w białą sukienkę i okryta białym płaszczem ozdobionym czerwonymi kwiatami, pomiędzy dolnymi zawieszone zostały girlandy korali. Ma złożone w modlitwie dłonie, a jej głowę zdobi korona. Ponad figurą umieszczony został czerwony baldachim zwieńczony trzema wiązkami białych piór i ozdobiony półprzezroczystą białą tkaniną. Po bokach głowy Marii znajdują się cztery postacie świętych. Jeden $\mathrm{z}$ nich odziany jest w jezuicką sutannę, obok widać klęczącego nagiego pustelnika; Jorge Bernales Ballesteros interpretuje te postacie jako św. Ignacego Loyolę i św. Hieronima ${ }^{53}$. Po drugiej stronie umieszczony został inny pustelnik, którego ciało okrywają włosy, zapewne św. Onufry, oraz starszy, siwy brodaty mężczyzna pogrążony w modlitwie, być może św. Piotr.

Ołtarz ukazujący Ostatnią Wieczerzę i scenę adoracji Eucharystii jest największy ze wszystkich znajdujących się na obrazach (ilustr. 7). Jorge Bernales Ballesteros uważa, że być może rozpoczynał całą serię jako moment ukonstytuowania się sakramentu Eucharystii, który jest tematem dominującym kuzkeńskich ołtarzy ${ }^{54}$. Jak większość, jest on trzykondygnacyjny, ale bardzo szeroki, a dodatkowo towarzyszą mu dekoracje malarskie zawieszone na ścianie budynku, przed którym został wzniesiony. Umieszczony został na barwnym dywanie, wokół postawiono pięć stoliczków, na których znajdują się doniczki z bogatymi kompozycjami kwiatowymi (można rozpoznać lilie i róże) oraz cztery dekoracyjne poduszki. Postument ma plastyczną formę złożoną z dwóch prostych ścianek na skraju i czterech wygiętych elementów wysuwających się do przodu w części środkowej, jego ścianki przyozdobiono tkaniną lub płytami pokrytymi ornamentem, na skraju dodatkowo umieszczono po jednym kwadratowym lustrze w bogatych ramach. Na wyższej kondygnacji znajduje się główna scena Ostatniej Wieczerzy. Ricardo Mariátegui Oliva uważa, że jest to rzeczywista grupa rzeźbiarska, która w tym czasie znajdowała się w klasztorze augustianów, a wykonał ją Lorenzo Machucama dla jednego z bractw religijnych funkcjonującego przy kościele San Agustín ${ }^{55}$. Zebranym wokół Chrystusa apostołom towarzyszą dwaj aniołowie. Po bokach umieszczono dodatkowo dwa łuki ozdobione piórami, a pod nimi, na ażurowych postumentach, postacie aniołów

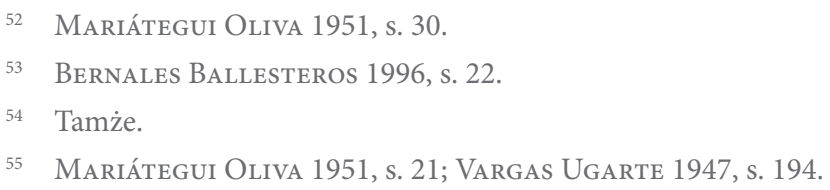




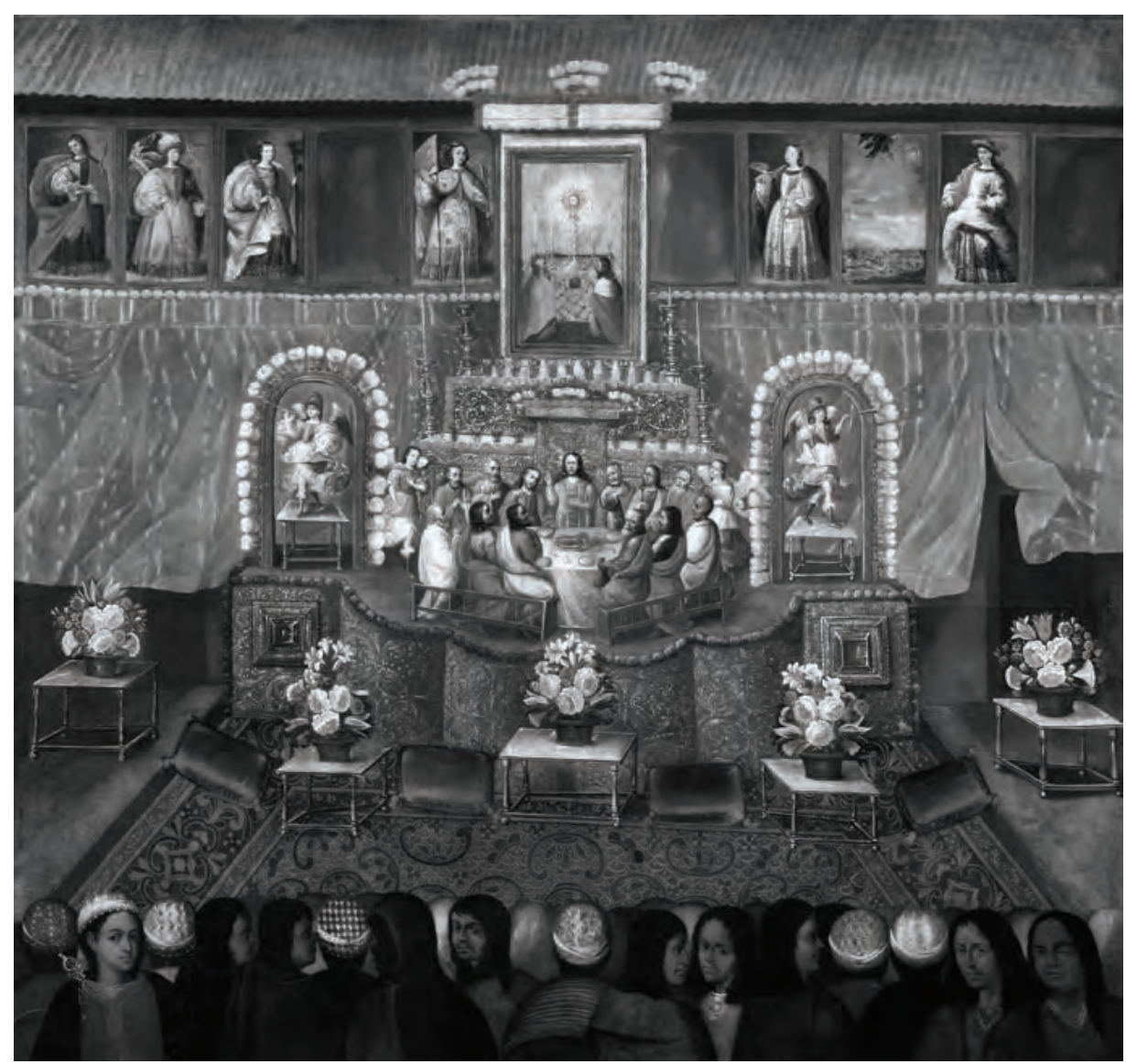

7. Ołtarz Ostatniej Wieczerzy, cykl malarski Corpus Christi, ok. 1675-1680, olej na płótnie, Museo de Arte Religioso, Cusco, Peru, fot. E. Kubiak

grających na trąbach. W tle Ostatniej Wieczerzy znajduje się dwukondygnacyjna konstrukcja pokryta srebrnymi płytami ozdobionymi dekoracją ornamentalną. Po bokach na każdym poziomie umieszczono po dwa świeczniki. Ponad postacią Chrystusa, zajmującą centrum kompozycji, znajduje się baldachim ozdobiony piórami. Całość ołtarza zwieńczona jest malarskim przedstawieniem adoracji Eucharystii. Monstrancja z Ciałem Chrystusa umieszczona jest na ołtarzu pomiędzy świecami, przed nim klęczą dwie postacie. Ponad obrazem znajduje się kolejny baldachim, także ozdobiony piórami. Ołtarz umieszczono na tle czerwonej ozdobnej tkaniny, zaś w górnej części zaobserwować można rząd obrazów z wizerunkami świętych, wśród których da się rozpoznać święte: Barbarę, Urszulę i Otylię.

Pierwszy z dwóch ołtarzy Ukrzyżowania znajduje się na obrazie ukazującym procesję z idącym w niej corregidorem Cusco Alonsem Pérezem de Gúzmanem (ilustr. 8) w grupie kleryków. Ukazany w tle ołtarz ma rozbudowaną wertykalną strukturę. Na dość solidnej podstawie o kształcie zbliżonym do kwadratu i obłożonej tkaniną z ornamentem (lub też metalowymi albo srebrnymi płytami) znajduje się trzykondygnacyjna piramidalna konstrukcja pokryta lustrami. Tuż nad 
podstawą umieszczono wizerunek Matki Boskiej Bolesnej w czerwonej sukni i niebieskim płaszczu z fragmentem tkaniny narzuconej na głowę. Po bokach konstrukcji znalazło się miejsce dla dziesięciu postaci anielskich, ośmiu świeczników, sześciu wazonów z kwiatami oraz dwóch z bukietami piór. Ołtarz zwieńczony jest rzeźbionym krucyfiksem umieszczonym na dekoracyjnej podstawie. Figura znajduje się na czerwonym tle rozwieszonej tkaniny, nakryto ją baldachimem w tym samym kolorze, ozdobionym trzema bukietami białych piór. Po obu stronach Ukrzyżowania są wizerunki archaniołów - św. Michała i Gabriela, dalej poziome kompozycje krajobrazowe oraz kolejne dwa wizerunki anielskie $\mathrm{z}$ atrybutami, po lewej umieszczono anioła z kolumną biczowania, a po prawej z płomieniem. Całość konstrukcji ołtarzowej znajduje się na tle czerwonej tkaniny zawieszonej na ścianie budynku.

Drugi ołtarz Ukrzyżowania towarzyszy procesji franciszkanów ${ }^{56}$ (ilustr. 9). Scena ukazana na obrazie rozgrywa się pomiędzy głównym placem miejskim (Plaza de Armas) a placem handlowym (Plaza de Regocijo). Arkady przyziemi przysłonięte zostały czerwonymi tkaninami; ponad nimi, na wysokości krucyfiksu, zawieszono obrazy przedstawiające aniołów i świętych. Najbliżej Ukrzyżowanego znajdują się Archanioł Michał i Archanioł Gabriel, następnie św. Urszula i św. Helena, dalej kolejne dwa wizerunki aniołów (jeden pozbawiony atrybutów, a drugi z sercem w dłoni) oraz kolejne dwa przedstawienia trudnych do zidentyfikowania świętych. Na skraju umieszczono - jeden nad drugim - pejzaże. Sam ołtarz składa się z czterech piramidalnie ustawionych cokołów ozdobionych najprawdopodobniej srebrnymi blachami ze stylizowanym ornamentem roślinnym oraz owalnymi kartuszami ujętymi rolwerkami. Na każdym z poziomów konstrukcji znajdują się postacie anielskie, łącznie pięć par. Pomiędzy nimi umieszczono niewielkie wazony z kwiatami bądź piórami, a na najniższej kondygnacji także lustra i sześć świeczników. Najwyższa kondygnacja zwieńczona została niewielką niszą umieszczoną na postumencie, nakrytą kopułką i flankowaną po bokach fantazyjnie wygiętymi kolumnami salomonowymi. W niszy znajduje się krucyfiks wykonany - zdaniem Ricarda Mariátegui Olivy - z kości słoniowej ${ }^{57}$.

Ołtarz z przedstawieniem obrony Eucharystii (ilustr. 10) znajduje się na obrazie ukazującym członków dwóch bractw niosących figury będące pod opieką konfraterni: św. Róży z Limy oraz Matki Boskiej zwanej La Linda (Piękna). Konstrukcja ołtarza jest trójkondygnacyjna, dolny poziom tworzy rodzaj rozczłonkowanego cokołu obłożonego płytami pokrytymi ornamentem, a na nim ustawiono kolejną, nieco mniejszą platformę ozdobioną obrazami. Na dwóch skrajnych widać wizerunki świętych, na dwóch środkowych umieszczono sceny Chrztu Chrystusa w Jordanie oraz przyjęcia sakramentu Eucharystii, a wokół umieszczone zostały cztery figury ubranych z przepychem aniołów oraz świeczniki i wazony z piórami. Kondygnację zamyka dekoracja $\mathrm{z}$ wielobarwnych sztucznych kamieni. Ołtarz wieńczy scena

\footnotetext{
56 Jest to jeden z tych obrazów, które znajdują się w prywatnej kolekcji w Chile.

57 W moim przekonaniu określanie materiału wykonania rzeźby na podstawie obrazu wydaje się dość ryzykowne; Mariátegui Oliva 1954, s. 17.
} 
obrony Eucharystii. W centrum kompozycji umieszczona została na podwyższeniu (globie i kolumnie) monstrancja z Najświętszym Sakramentem. Po jednej stronie widać postać króla hiszpańskiego ze szpadą wzniesioną do obrony Eucharystii przed niewiernym (Turkiem czy też muzułmaninem przedstawionym $\mathrm{w}$ orientalnych szatach z turbanem na głowie), który próbuje ściągnąć monstrancję z piedestału. W tym wypadku jest to wizerunek panującego wówczas Karola II, u którego stóp przedstawiono lwa, symbol Hiszpanii. Niewiernemu towarzyszy demon ${ }^{58}$. Scena została umieszczona na podwyższeniu ozdobionym lustrami. Tło przedstawienia stanowi jasna tkanina zwieńczona szczytem o łuku odcinkowym ozdobionym wielobarwnymi piórami. Po bokach obrony Eucharystii widnieją postacie dwóch uskrzydlonych, nagich geniuszy, na długich trąbach obwieszczających triumf Najświętszego Sakramentu. Towarzyszą im świeczniki oraz wazony z kwiatami i piórami.

Ołtarz Najświętszego Sakramentu znajduje się na obrazie ukazującym procesję zakonu augustianów ${ }^{59}$ (ilustr. 11). Konstrukcja złożona jest z pięciokondygnacyjnej, piramidalnie skomponowanej podstawy oraz wieńczącego całość niewielkiego tabernakulum z niszą, flankowanego kolumnami salomonowymi i nakrytego kopukką, z monstrancją i Najświętszym Sakramentem. Lica poszczególnych poziomów ołtarza w większości dekorowane są lustrami, jedynie na najniższej kondygnacji znajdują się przedstawienia Marii z Dzieciątkiem i św. Józefa z Dzieciątkiem oraz kompozycje krajobrazowe. Każdy z poziomów flankowany jest postaciami anielskimi stojącymi na skraju konstrukcji, a dodatkową ozdobę stanowią wazoniki z piórami oraz świeczniki. Ołtarz umieszczono na tle czerwonej tkaniny, natomiast po bokach Najświętszego Sakramentu znajdują się wizerunki królów i proroków starotestamentowych ${ }^{60}$, wśród których możemy bez wątpliwości rozpoznać postacie Mojżesza z rogami oraz Dawida z harfą, a na podstawie porównań ikonograficznych hipotetycznie określić także pozostałych - są to: Izajasz, Salomon (ilustr. 12), Jeremiasz i Eliasz ${ }^{61}$. Po prawej stronie ołtarza, w pewnym oddaleniu, znajduje się umieszczony pod niewielkim baldachimem portret Karola II, króla Hiszpanii, ostatniego panującego z dynastii Habsburgów. Zarówno Mariátegui Oliva, jak i Bernales Ballesteros ${ }^{62}$ słusznie zauważają zależność kompozycji wizerunku królewskiego od obrazów Juana Carreña de Mirandy ${ }^{63}$.

\footnotetext{
58 DeAn 2002 [1999], s. 93.

59 Jest to drugi z trzech obrazów znajdujących się w prywatnej kolekcji w Chile.

60 Ricardo Mariátegui Oliva rozpoznaje postacie jako „świętych i męczenników kościoła” (santos y mártires de la Iglesia); MARIátegui Oliva 1954, s. 18. Jorge Bernales Ballesteros również widzi w tych postaciach świętych, między innymi królów: Ludwika Świętego i Świętego Fernanda; Bernales BALlesteros 1996, s. 28.

${ }^{61}$ Jako materiał porównawczy posłużyły prace Agustiny Rodríguez Romero $(2001,2012)$.

62 Mariátegui Oliva 1954, s. 18; Bernales Ballesteros 1996, s. 28.

63 W 1669 roku był mianowany „malarzem królewskim” przez sprawującą rządy w imieniu nieletniego króla Mariannę Habsburską. Zasłynął przede wszystkim jako portrecista na dworze Karola II i malarz portretów dziecięcych władcy; Pérez Sánchez 2005 [1992], s. 28, 292.
} 
TECHNE

T E X N H

SERIA NOWA

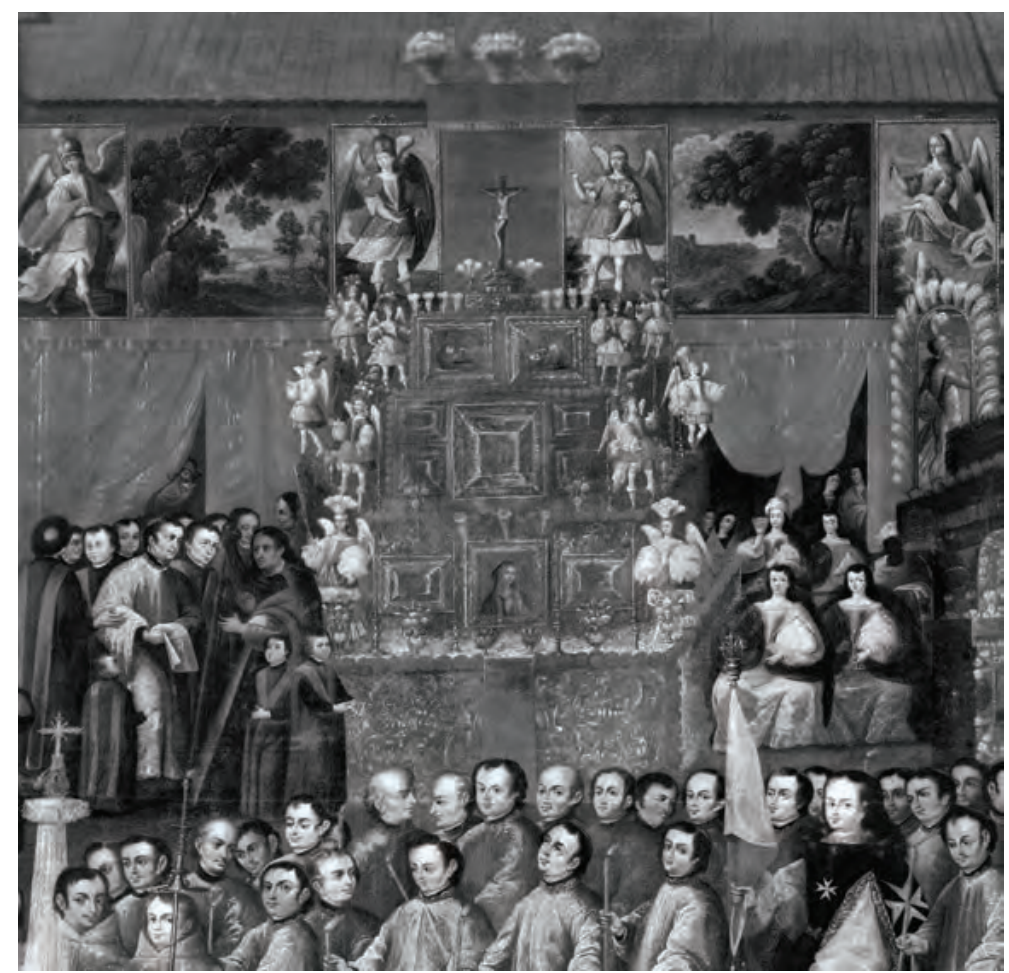

8. Ołtarz Ukrzyżowania, obraz procesji z przedstawieniem corregidora Alonsa Péreza de Gúzmana, cykl malarski Corpus Christi, ok. 1675-1680, olej na płótnie, Museo de Arte Religioso, Cusco, Peru fot. E. Kubiak

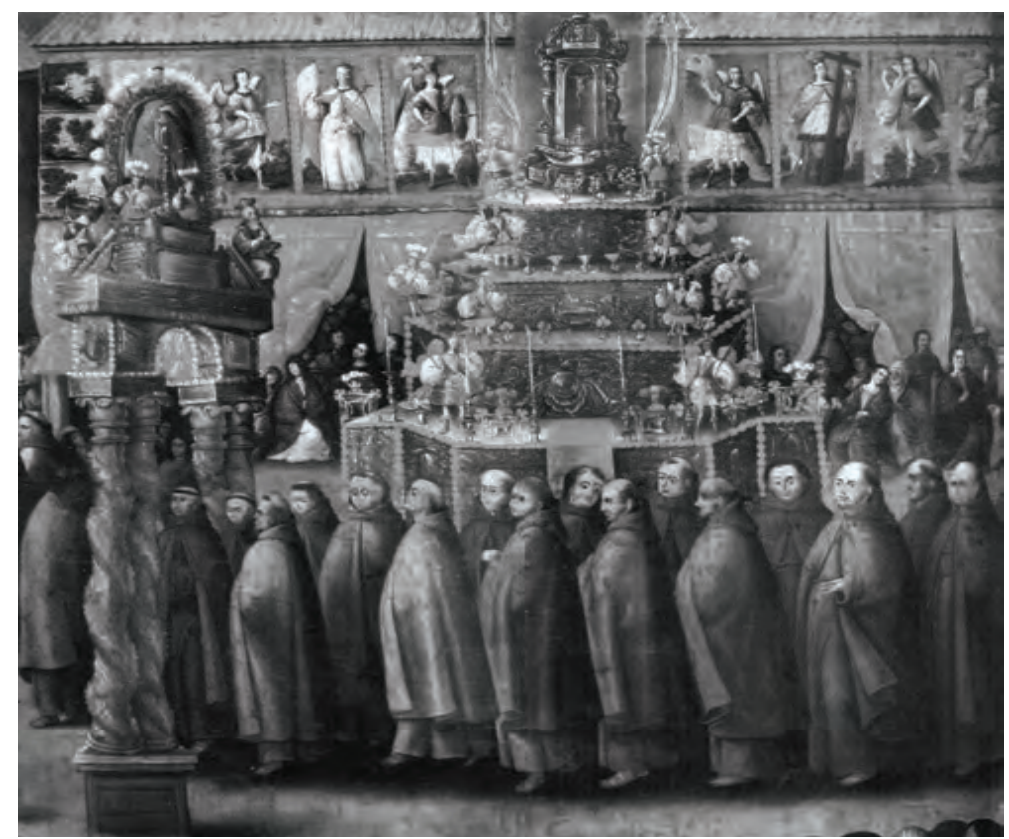

9. Ołtarz Ukrzyżowania, obraz procesji z zakonem franciszkanów, cykl malarski Corpus Christi, ok. 1675-1680, olej na płótnie, kolekcja prywatna, Chile, fot. Patricio Pueyrredón 


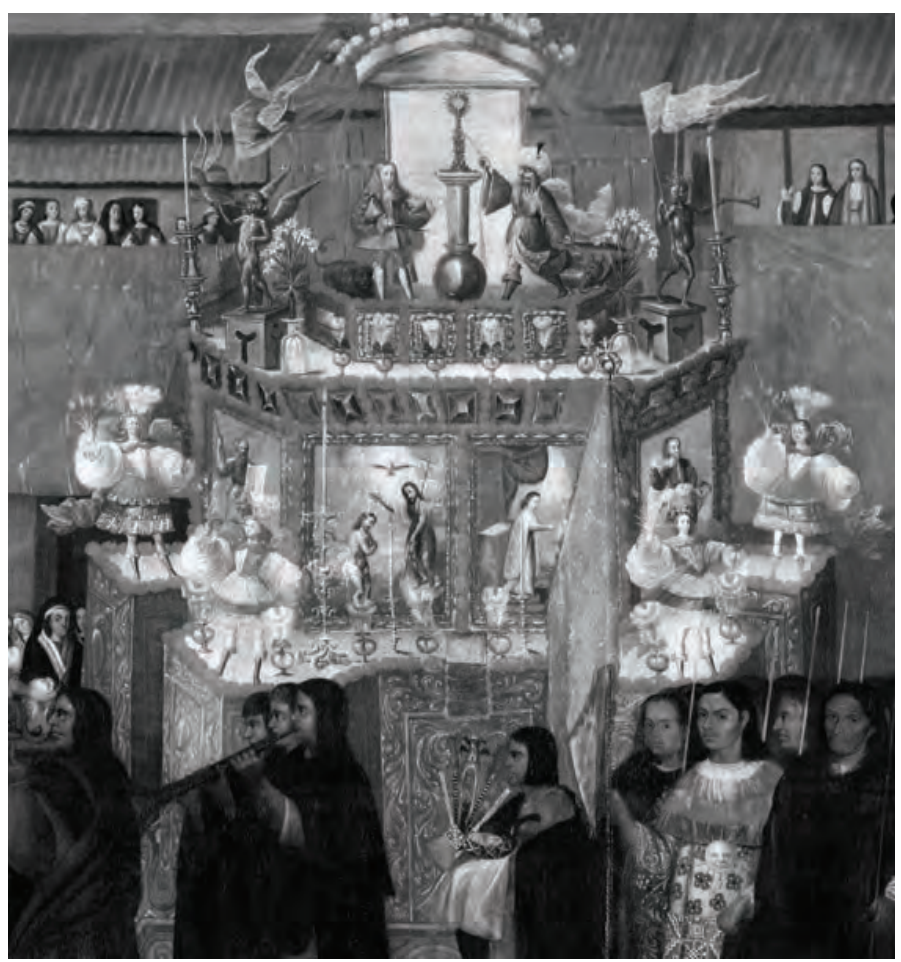

10. Ołtarz ze sceną Obrony Eucharystii na obrazie z przedstawieniem bractw św. Róży z Limy i Matki Boskiej Niepokalanie Poczętej (La Linda), cykl malarski Corpus Christi, ok. 1675-1680, olej na płótnie, Museo de Arte Religioso, Cusco, fot. E. Kubiak

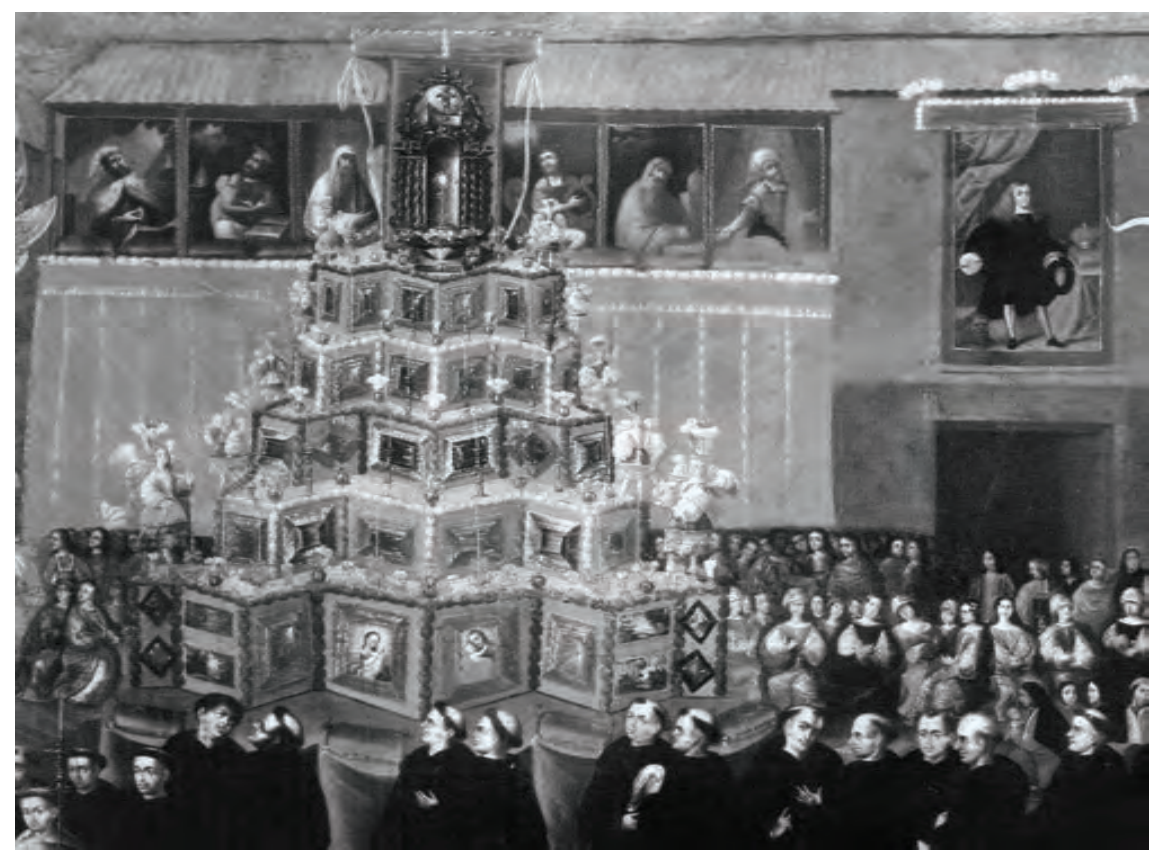

11. Ołtarz Najświętszego Sakramentu, obraz procesji z zakonem augustianów, cykl malarski Corpus Christi, ok. 1675-1680, olej na płótnie, kolekcja prywatna, Chile, fot. Patricio Pueyrredón 
Kolejny ołtarz, który możemy podziwiać na jednym z obrazów cyklu malarskiego z Cusco, poświęcony został Przemienieniu Pańskiemu (ilustr. 13) i uświetnia przedstawienie ukazujące procesję członków zakonu mercedariuszy ${ }^{64}$. Jest on znacznie skromniejszy od opisanych już ołtarzy, choć dość wysoki; składa się z trzech piramidalnie ustawionych, kolejno zmniejszających się elementów, obłożony został czerwoną, pokrytą ornamentem tkaniną łączoną koronkami, a na szczycie umieszczono obraz ze sceną Przemienienia Pańskiego. Ponad przedstawieniem malarskim znajduje się czerwony baldachim zwieńczony trzema wiązkami białych piór. Po bokach konstrukcji na pierwszym i drugim poziomie siedzą cztery postacie Ojców Kościoła. Dekoracji dopełniają świeczniki oraz wazony z piórami.

Ostatni z ołtarzy, które odnaleźć można na obrazach serii kuzkeńskiej, jest poświęcony Dzieciątku Jezus (Niño Jesús) ${ }^{65}$ (ilustr. 14). Składa się z trzech kolejno zmniejszających się platform, których lica okrywa złocona blacha ozdobiona stylizowanym ornamentem roślinnym oraz owalnymi medalionami, zamkniętymi od góry i od dołu rolwerkami. Na szczycie kompozycji znajduje się ażurowy, czterokondygnacyjny cokolik dekorowany wolutami i ornamentem roślinnym, na którym ustawiono figurkę Dzieciątka Jezus. Za plecami postaci rozwieszono zieloną tkaninę, a ponad głową umieszczono baldachim ozdobiony trzema pękami piór. Chrystus odziany został w czerwoną tunikę oraz płaszcz z dekoracyjnym kołnierzem i mankietami wykonanymi z koronki. Na głowie Jezusa spoczywa korona, jedną rękę unosi w geście błogosławieństwa, w drugiej trzyma glob ziemski. Na ołtarzu znajduje się także siedem postaci anielskich, każda z palmą męczeństwa w dłoni, z czego czterej aniołowie trzymają też bukiety kwiatów, a dwaj inni świece. Uwagę zwraca ozdoba głów anielskich, ponieważ każda z nich zwieńczona jest pióropuszem, przy czym pióropusze postaci towarzyszących Jezusowi są ogromnych rozmiarów i stanowią jedną trzecią wysokości każdej figury. Dekoracji dopełniają bukiety kwiatów i piór ustawione w wazonikach, a także świeczniki przeznaczone na pojedyncze świece. Ołtarz ustawiono przed kościołem jezuitów, przy portalu znajduje się grupa zakonników, a w ich kierunku zmierza anda z figurami dwóch świętych. Początkowo byli oni interpretowani jako święci jezuiccy Ignacy Loyola i Franciszek Ksawery ${ }^{66}$, jednak zgodnie z ustaleniami Eduarda Wuffardena możemy przyjąć, że najprawdo-

${ }^{64}$ Orden Real y Militar de Nuestra Señora de la Merced y la Redención de los Cautivos, albo krótsza, znacznie popularniejsza nazwa: Orden de la Merced. Zakon założony w 1218 roku przez św. Piotra Nolasco jako zakon hiszpański rozpowszechnił się przede wszystkim na samym Półwyspie Iberyjskim oraz w Ameryce Łacińskiej. Istnieje informacja o fundacji klasztoru mercedariuszy w Cusco w 1537 roku; ViñUales 2004, s. 94.

65 W taki sposób postać ta jest zinterpretowana także przez Carolyn Dean oraz Ricarda Mariátegui Olivę (Dean 2002 [1999], s. 91; Mariátegui Oliva 1951, s. 30). Natomiast Jorge Bernales Ballesteros błędnie opisuje figurę wieńczącą ołtarz jako przedstawienie maryjne (Virgen) (BERNALES BALLesteros 1996, s. 27).

66 Tak interpretuje postacie Ricardo Mariátegui Oliva (1951, s. 31). Jorge Bernales Ballesteros natomiast uważa, że świętemu Ignacemu towarzyszy kanonizowany w 1671 roku Franciszek Borgiasz (Bernales Ballesteros 1996, s. 27). 

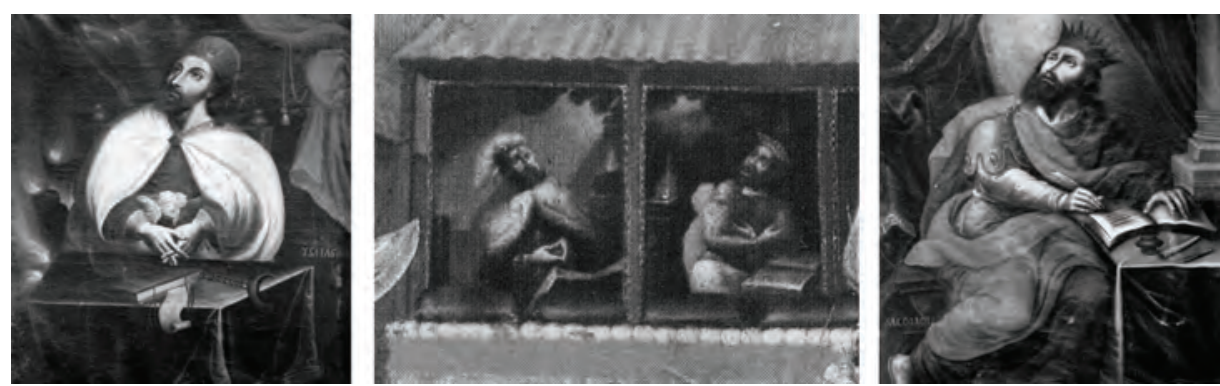

12. Izajasz, XVII wiek, San Miguel, Tomave, Boliwia, fot. Marcela Corvera [archiwum PESCA]; Izajasz i Salomon na obrazie z przedstawieniem procesji augustianów, cykl malarski Corpus Christi, ok. 1675-1680, ole na płótnie, kolekcja prywatna, Chile, [fot. Patricio Pueyrredón]; Salomon XVII wiek, San Miguel, Tomave, Bolivia, fot. Marcela Corvera [archiwum PESCA]

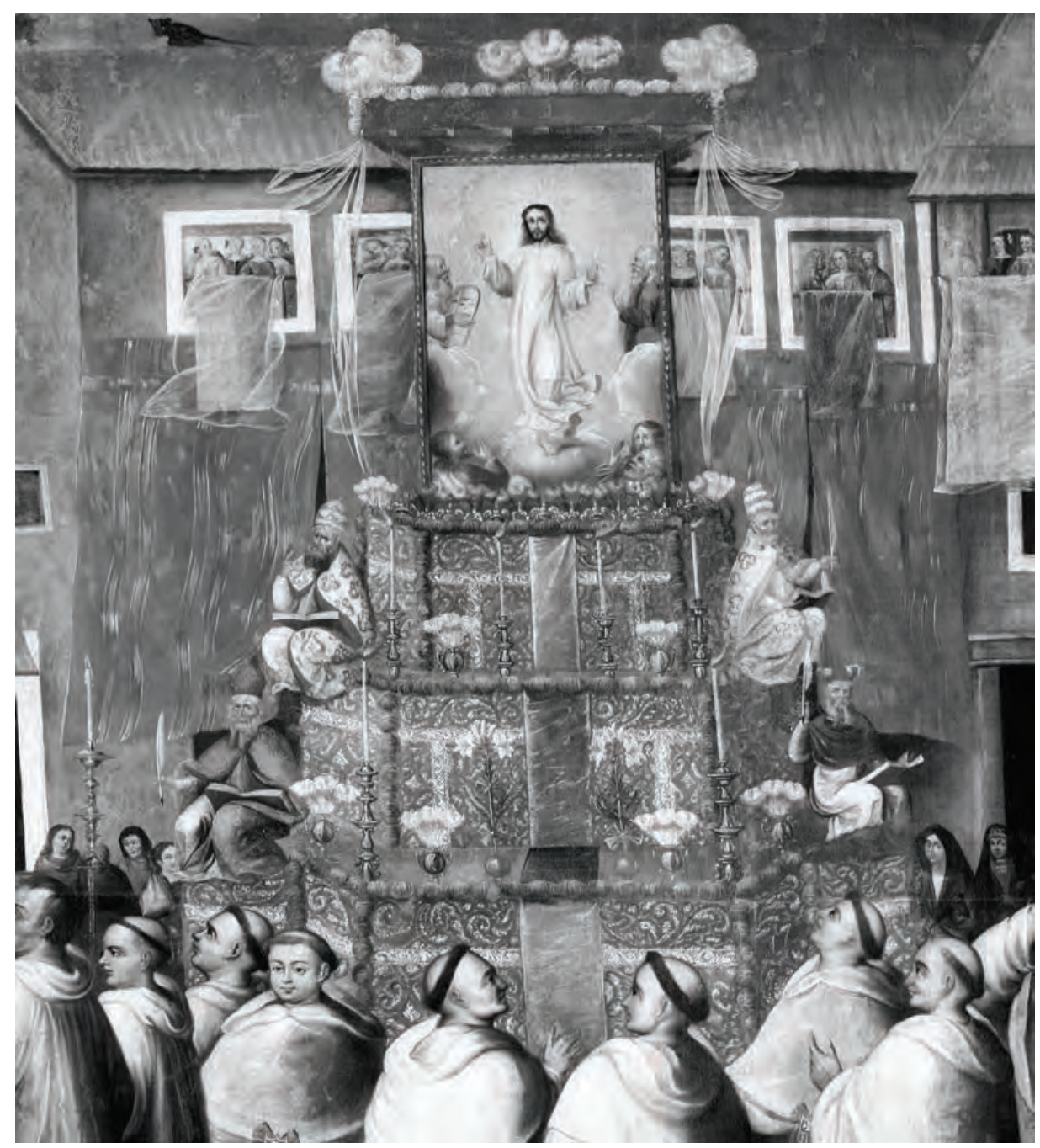

13. Ołtarz Przemienienia Pańskiego, obraz procesji z zakonem mercedariuszy, cykl malarski Corpus Christi, ok. 1675-1680, olej na płótnie, Museo de Arte Religioso, Cusco, Peru, fot. E. Kubiak 
TECHNE

T E X N H

SERIA NOWA

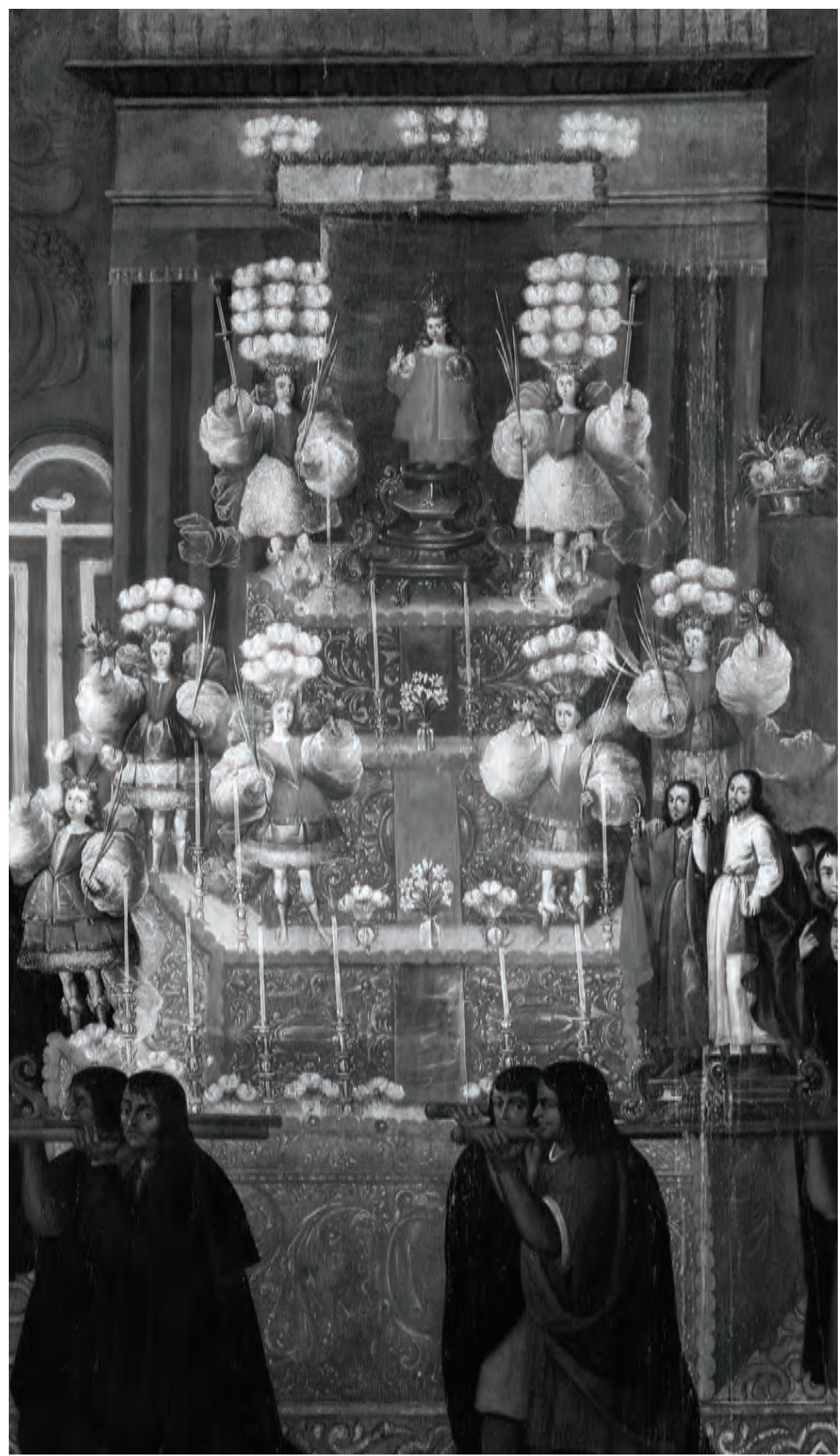

14. Ołtarz Dzieciątka Jezus (Niño Jesús), obraz z przedstawieniem zakonu jezuitów, cykl malarski Corpus Christi, ok. 1675-1680, olej na płótnie, Museo de Arte Religioso, Cusco, Peru, fot. E. Kubiak 
podobniej zostali tu przedstawieni święci Kosma i Damian, patroni bractwa chirurgów i fryzjerów, które funkcjonowało przy kościele jezuitów ${ }^{67}$.

Jak pisze Carolyn Dean, ołtarz prezentowany na obrazie bez wątpienia został wzniesiony przez Bractwo Dzieciątka Jezus (Cofradía de Niño Jesús), które w tym czasie funkcjonowało przy kościele jezuitów i zrzeszało ludność tubylczą ${ }^{68}$. Znamy zresztą kontrakt dotyczący ozdobienia ołtarza Dzieciątka Jezus z 1667 roku dla kościoła jezuitów zawarty pomiędzy artystą pochodzącym z Acopii, Diego Huallpą, a przełożonymi bractwa Antoniem Huamanem Vilką, Pasqualem Quispem i Domingo Ramosem, gdzie zobowiązywano artystę do wykonania złocenia elementów konstrukcyjnych: szafek i piedestału (alacenas, peaña) oraz rzeźb ośmiorga dzieci ${ }^{69}$ (czyli aniołów $)^{70}$. Nie wiemy, czy jest to umowa dotycząca ołtarza na stałe znajdującego się w kościele jezuitów, czy też konstrukcji procesyjnej wykorzystywanej w czasie świąt. Dziś ołtarza o takim wezwaniu nie ma, wymieniają go natomiast inwentarze z czasów wygnania jezuitów (1767), znajdował się on wówczas w kaplicy Matki Boskiej Loretańskiej (Nuestra Señora de Loreto) ${ }^{71}$.

Jak już zostało wspomniane, ołtarze XVIII-wieczne znamy tylko z opisów zawartych w aktach notarialnych dokumentujących ich powstanie lub wykończenie. Nie wszystkie z tych opisów są jednakowo szczegółowe, a większość ich można uznać za raczej zdawkowe, czasem pojawia się jednak odwołanie do projektu-rysunku, który nie zachował się do dziś. Najwcześniejsza znana umowa pochodzi z 1712 roku - kontrakt na wzniesienie ołtarza na procesję Bożego Ciała zawarty został pomiędzy „mistrzem ołtarzowym” (maestro altarero) Salvadorem Sanchezem i mistrzem kowalskim (maestro herrador) Francisco Muñozem z jednej strony a przedstawicielem cechu kowalskiego jako fundatorem. W opisie zaznaczono, że ołtarz ma być ozdobiony „trzydziestoma przystrojonymi dziećmi, i więcej, dwudziestoma płytami", a całość ma budzić zachwyt ${ }^{72}$.

Najbardziej bogata w informacje dotyczące wyglądu i programu ikonograficznego ołtarza jest umowa pomiędzy Gerónimem de Lozadą i przedstawicielami gildii handlowej (diputados del comercio) ${ }^{73}$, w której zawarto ustalenia dotyczące

\footnotetext{
67 WUfFARDEN 1996, s. 94.

68 Dean 2002 [1999], s. 91; Donato Amado 2017, s. 58.

${ }_{69}$ Pod tym określeniem rozumiano najprawdopodobniej dziecięce postacie anielskie, które zostały potraktowane w tym artykule jako stały element dekoracji architektury efemerycznej i ich charakterystyka znajduje się w części poświęconej formie ołtarzy.

70 Cornejo Bouroncle 1960, s. 69.

${ }^{71}$ Iten al lado derecho esta otro altar del Niño Jesús con su vestido de Brocate Carmesí y cinco laminas que adornan („Iten po prawej stronie znajduje się inny ołtarz Dzieciatka Jezus ubranego w strój z karmazynowego brokatu i pięć płyt, które go ozdabiają”), AGNP, Fondo: Temp. (Inventarios), Caja 1 Legajo 13 (1767), f. 56 v. Także: ANCh, Fondo Jesuitas, sygn. 347, f. 263 v.

72 Cornejo Bouroncle 1960: 266-267; con treinta niños vestidos y mas veinte laminas; ARC, Sección Notarial, Gregorio Serrano Basquez (62), f. 92v.-93r.

73 Kontrakt został opisany po raz pierwszy w pracy Jorge’a Cornejo Bouroncle’a (CoRnejo BouRONCLE 1960, s. 298); autor notuje datę kontraktu - 29 marca 1739 roku. Ten sam rok powstania
} 
TECHNE

T E X N H

SERIA NOWA

zbudowania ołtarza na czas procesji Bożego Ciała w 1740 roku. Mensę miały osłaniać trzy antependia, jedno wykonane ze srebra i dwa pozostałe z tkaniny, a po bokach dodatkowo planowano umieścić płyty, najprawdopodobniej z metalu. Jako ozdobę kolejnej kondygnacji przewidziano wizerunki 12 proroków, 12 apostołów oraz kilka przedstawień nienazwanych z imienia świętych, a dodatkowo miało być tam umieszczonych „czterdzieścioro wystrojonych dzieci” (cuarenta niños vestidos). Najwyższa kondygnacja liczyła mniej postaci, ale według opisu była bardziej skomplikowana kompozycyjnie. Miało ją ozdabiać 12 dzieci oraz 12 płyt, uporządkowanych po sześć z każdej strony. Wydaje się, że jako centrum kompozycji przewidziane zostały wizerunki dwóch cherubinów umieszczonych na płytach z szylkretu i zamkniętych w arkadach. Każdy $\mathrm{z}$ aniołów miał posiadać odpowiedni strój, bukiet i kwiaty w dłoniach, a ozdabiać je miały „cztery tuziny białych piór” (cuatro docenas de plumas blancas). Całość dopełniały dwa rodzaje świeczników przeznaczone na świece dużych rozmiarów (hacheros i blandones) oraz 60 luster. Przed ołtarzem przewidziano umieszczenie wizerunku władcy Hiszpanii - „płótna z portretem króla Filipa V" (un lienzo del retrato del rey don Phelipe Quinto) ${ }^{74}$.

Pozostałe zachowane umowy dotyczące budowy ołtarzy nie zawierają tak wielu informacji na temat formy powstających obiektów. W kontrakcie podpisanym rok wcześniej przez tego samego artystę, Gerónimo de Lozadę, z przedstawicielami kupców (mercaderes) Podro Lanillją, Ascenciónem Floresem i Roqueem Aspilcuetą, czytamy jedynie, że ołtarz ma być wykonany „przyzwoicie i z całą starannością”75.

W kontrakcie z 1773 roku, podpisanym przez „mistrza ołtarzowego” Bernarda Dávalosa i przedstawiciela cechu pisarzy Hermenegilda Gamboę, zawarto zobowiązanie dostarczenia przez zamawiających odpowiednich materiałów i elementów dekoracji - tak, aby ołtarz prezentował się z „odpowiednią świetnością” (el lucimiento necesario) ${ }^{76}$.

$\mathrm{Na}$ koniec warto jeszcze krótko scharakteryzować artystów zaangażowanych w powstawanie ołtarzy procesyjnych. Większość z nich określano mianem "mistrza ołtarzowego" (maestro altarero) lub też „mistrza od łuków” (maestro arcero $)^{77}$ - często ci sami wykonawcy wznosili ołtarze i procesyjne łuki triumfalne oraz inne rodzaje architektury efemerycznej. Na przykład w kontrakcie z 1702 roku Joseph de Ochoa, określony jako altarero, został zatrudniony do wzniesienia łuku triumfalnego ${ }^{78}$. Większość twórców pozostaje anonimowych, w księgach rachunkowych bractw religijnych wymieniana jest zwykle kwota przeznaczona dla

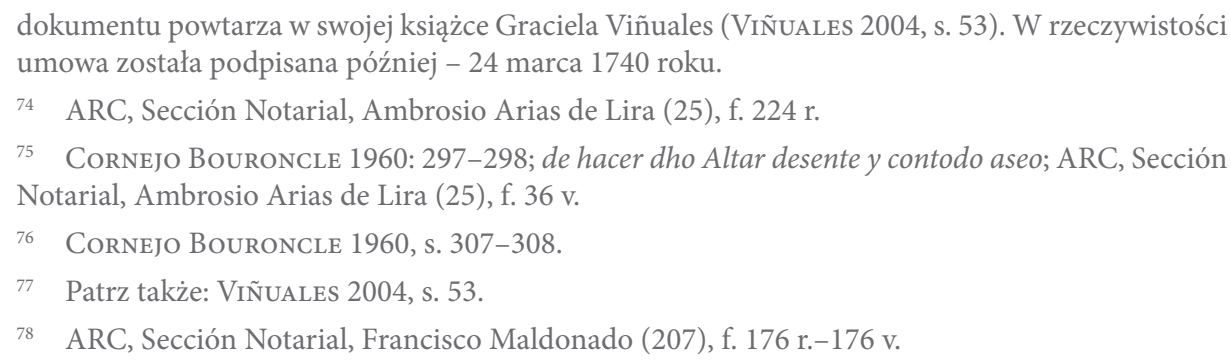


alterero, często określono zakres jego prac, ale jego nazwisko pozostawało nieznane. Wiemy na przykład, że Cofradia de Santa Cruz w kościele San Jerónimo zapłaciła w 1746 roku „dwanaście pesos mistrzowi ołtarzowemu za udekorowanie kościoła i przygotowanie platformy procesyjnej" ${ }^{\prime 79} \mathrm{w}$ związku z przygotowaniami do obchodów w dzień Krzyża Świętego. Bractwo świętego Hieronima w tym samym kościele opłaciło mistrza ołtarzowego i dekorację kościoła w dzień patrona $(1753)^{80}$, ale znów nie wiemy, komu zlecono prace. Nazwiska artystów znamy niemal wyłącznie z wyżej opisanych kontraktów. Trzeba zaznaczyć, że kilka nazwisk powtarza się, co możemy potraktować jako świadectwo popularności niektórych twórców. Cieszył się nią z pewnością Gerónimo Lozada, który w kolejnych latach - 1739 i 1740 - podpisał kontrakty na wykonanie ołtarzy na procesję Bożego Ciała ${ }^{81}$. Także Juan de Becerra został najęty do wykonania konstrukcji ołtarzy procesyjnych w latach 1718 i $1723^{82}$, ale był on również twórcą monumentu wzniesionego $\mathrm{w}$ wielki czwartek wewnątrz kuzkeńskiego kościoła klarysek ${ }^{83}$. Czasami też wzywani byli do pomocy mistrzowie innych profesji. W kontrakcie z 1712 roku czytamy, że mistrz kowalski Francisco Muñoz został zobowiązany do współpracy przy wznoszeniu ołtarza i miał wykonać postacie dzieci „pięknie ubrane” oraz płyty, a także wznieść drewniane rusztowanie (armazón de madera), na którym wsparty będzie ołtarz ${ }^{84}$.

\section{Struktura, elementy dekoracji i wykorzystywane materiały}

Wydaje się, że w drugiej połowie XVII wieku oraz w XVIII stuleciu struktura ołtarzy procesyjnych wznoszonych w Cusco podczas Bożego Ciała była podobna. Zwykle miały one formą piramidalną, przy czym podstawę stanowiła mensa ołtarzowa, wyróżniająca się dekoracją i obowiązkowo zakrywana antependium (frontal). Liczba poziomów była różna, każdy ołtarz liczył co najmniej dwa, ale - jak się wydaje, patrząc na obrazy kuzkeńskiego cyklu malarskiego - zdarzały się także monumentalne konstrukcje osiągające sześć lub siedem kondygnacji. Wydaje się, że taka forma ołtarzy procesyjnych była typowa dla regionu andyjskiego. W Potosi w czasie procesji Bożego Ciała w 1720 roku zakon mercedariuszy wzniósł ołtarz „Zwieńczony schodami zmniejszającymi się jak piramida"85, który znajdował się na placu cmentarnym przed kościołem zakonu; o szczegółach jego formy poinformował nas XVIII-wieczny kronikarz z Potosi Bartolomé Arzáns Orsúa y Vela.

\footnotetext{
79 Dose p.s al Altarero por el adorno de la Yglesia y la Compostura de la Anda; AAC, Colonia, Cofradías, 1653-1768, Stma. Vera Cruz, f. 69 v.

80 Ytt. en el altarero y Adorno de la Yglesia, AAC, Colonia, Cofradías, 1661-1768, S. Jerónimo, f. $55 \mathrm{v}$.

81 ADC, Sección Notarial, Ambrosio Arias de Lira (25), f. 36 v.-37 r. i f. 224 r.-225 v.

82 Tamże, Sección Notarial, Mathias Ortega Ximenez (313), f. 121 r.-121 v.; tamże, Mathias Ortega Ximenez, (318), f. 90 v.-f. 91 r.

83 Tamże, Sección Notarial, Agustin de Aguila Morillas (18), f. 207 r.-f. 207 v.

84 Tamże, Sección Notarial, Gregorio Serrano Basquez (62), f. 93 r.

85 En los remates de las gradas, que fenecían como pirámides; Arzáns Orsúa y Vela 2012, s. 103.
} 
Ważnymi składowymi struktury ołtarzowej były też elementy architektoniczne, jak kolumny, łuki czy kopułki; wszystkie widoczne są na ołtarzach prezentowanych na obrazach, a niektóre także wymieniane w kontraktach. Znów jako porównanie dla realizacji kuzkeńskich może służyć ten sam ołtarz z 1720 roku z Potosi. Konstrukcję wzniesioną przez mercedariuszy kronikarz opisuje jako „trójkątny ołtarz w porządku toskańskim z trzema łukami y takimiż trzema fasadami”" ozdobiony główną kopułą oraz kopułkami bocznymi.

Niemal wszystkie ołtarze kuzkeńskie wznoszone w czasie procesji dekorowane były postaciami dziecięcymi, czyli wizerunkami anielskimi. Widać to doskonale na obrazach, ale jest to też stały element spisywanych umów. Postacie anielskie pojawiają się także w ołtarzach innych rejonów andyjskich. I znów dla porównania w 1720 roku w Potosi ołtarz wzniesiony przez mercedariuszy ozdobiony był „dziećmi ubranymi w złote i srebrne szaty, z efektownymi z pióropuszami na głowach, przepasane bluszczem i dzikim wawrzynem, $\mathrm{z}$ donicami i kwiatami w dłoniach" ${ }^{\text {"7 }}$. Termin niños $\mathrm{w}$ tym kontekście pojawia się nie tylko $\mathrm{w}$ przypadku ołtarzy ustawianych w czasie procesji, ale również przy opisach tych, które znajdowały się w kościołach. $\mathrm{W}$ umowie z 1660 roku zawartej pomiędzy Juanem Calderonem, mistrzem złotniczym, a Bartoloméem de la Guerrą, dotyczącej pozłocenia ołtarza Nuestra Señora de la Soledad w kościele mercedariuszy w Cusco, czytamy, że pozłocone mają być zarówno retabulum, jak i „dzieci, które musi mieć wspomniany ołtarz"88. W zleceniu z 1663 roku czytamy, że w tym samym kościele mistrz złotniczy Martín de Loaiza ma pozłocić ołtarz w kaplicy San Pedro de Nolasco, a także „czworo dzieci i umieścić dwie cnoty w górze ołtarza"89.

Do konstrukcji ołtarzy wykorzystywano drewniany stelaż (armazón de madera), następnie dekorowano go, używając droższych i bardziej szlachetnych materiałów. Bardzo często antependium wykonywane było ze srebra, co potwierdzają zarówno źródła ikonograficzne, jak i informacje zawarte w dokumentach archiwalnych (umowa z 1740 roku). Przypominały one podobne elementy używane w architekturze wnętrz kościelnych. Najbardziej znaczącymi obiektami złotniczymi wykonywanymi w Cusco były monstrancje (w tym kustodie procesyjne), andas i właśnie antependia, które wykonywano często $\mathrm{z}$ arkuszy srebra i zdobiono $\mathrm{w}$ technice repusowania ornamentami bazującymi na grafikach pochodzących z europejskich wzorników. Często motywy dekoracyjne wzbogacano lokalnymi formami, pojawiają się zatem elementy ukazujące miejscową florę i faunę. Jako przykład może służyć antependium ołtarza głównego w katedrze kuzkeńskiej, które powstało pod koniec XVIII wieku ${ }^{90}$ (ilustr. 15).

\footnotetext{
86 (...) el altar trangular de orden Toscana; tamże, s. 102.

87 (...) niños vestidos de áurea y argentería, y las cabezas con plumas vistosas ceñidas con hiedra $y$ laurel a lo salvaje, macetas y flores de mano; tamże.

88 (...) y Niños que hay de tener dicho retablo; CoRnejo Bouroncle 1960, s. 60.

89 (...) cuatro niños y poner dos virtudes en los alto del retablo; tamże, s. 63-64.

90 Samanez Argumedo 2013, s. 100-102.
} 


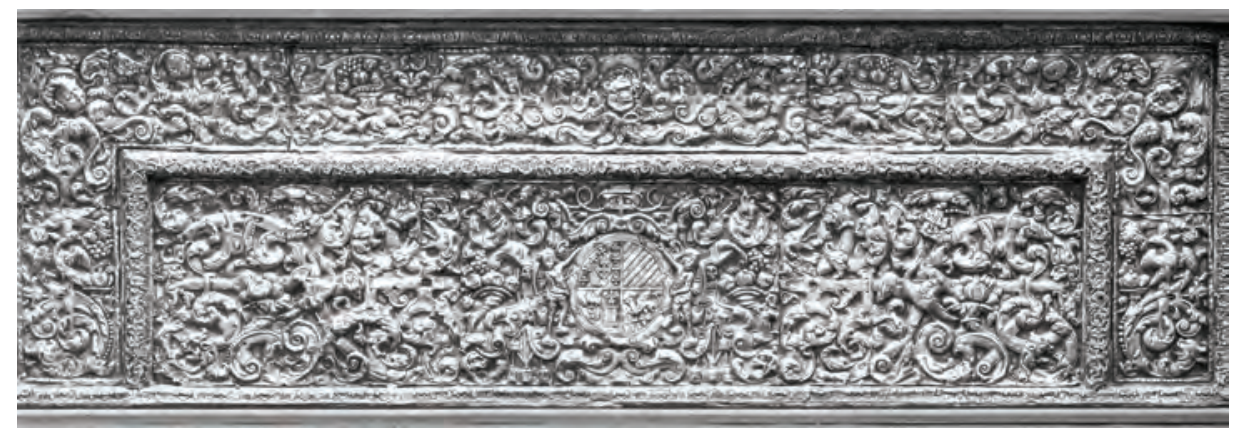

15. Antependium ołtarza głównego w katedrze kuzkeńskiej, koniec XVIII wieku, Cusco, Peru fot. E. Kubiak

Srebro wykorzystywano także do dekoracji łuków będących częścią składową ołtarzy oraz do wykonywania świeczników. Po raz kolejny możemy odnaleźć podobne elementy w ołtarzu procesyjnym z 1720 roku z Potosi, który posiadał „antependia

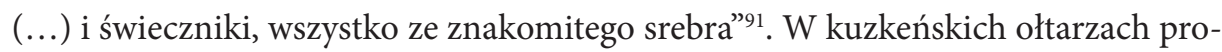
cesyjnych srebro pojawiało się ponadto jako dekoracja lica kolejnych kondygnacji, jednak, jak się wydaje, w wyższych kondygnacjach częściej wykorzystywano płyty metalowe oraz tkaniny. Trzeba zaznaczyć, że w dekoracji ołtarzy element tekstylny był również niezwykle istotny. Jednobarwne tkaniny rozwieszano na ścianach budynków i wykorzystywano jako tła dla konstruowanych monumentów oraz dekorację ulic, którymi przemieszczała się procesja ${ }^{92}$.

Do konstrukcji i dekoracji ołtarzy procesyjnych w Cusco wykorzystywano także maguey. W kontrakcie z 1773 roku podpisanym przez „mistrza ołtarzowego" Bernarda Dávalosa i przedstawiciela cechu pisarzy Hermenegilda Gamboę zawarto zobowiązanie dostarczenia przez zamawiających odpowiednich materiałów i elementów dekoracji (lechugillas, maguey) - tak, aby ołtarz prezentował się $\mathrm{z}$ „odpowiednią świetnością". Lechugillas to nazwa określająca roślinę bądź charakterystyczne wielowarstwowe kołnierze i mankiety hiszpańskie na terenie Półwyspu Iberyjskiego, typowe dla mody czasów Filipa II i Filipa III ${ }^{93}$, a w hiszpańskich koloniach zamorskich z pewnością dłużej. Maguey natomiast jest materiałem pochodzącym ze zdrewniałej centralnej części agawy, który wykorzystywany był w rzeźbiarstwie w okresie kolonialnym już od XVI wieku4. Maguey daje się łatwo formować,

\footnotetext{
91 (...) los frontales, (...) y blandones, todo de finisima plata. W opisnie wymienione są także: „trzy łuki z pierwszorzędnego srebra” (tres arcos de plata primorosa); ArzÁns Orsúa y VelA 2012, s. 103.

92 Rzadko znamy gatunki tkanin, ale w opisie łuku triumfalnego wzniesionego w 1691 roku w Cusco wśród materiałów wymieniona jest tafta; ConRnejo Bouroncle 1960, s. 85. Także w relacji Arzansa Orsuy y Veli pojawia się informacja, że ołtarz mercedariuszy w Potosi z 1720 roku był dekorowany między innymi jedwabiem; Arzáns Orsúa y Vela 2012, s. 102.

93 DRAE, hasło: lechuguilla.

94 Według Jorge Floresa Ochoa, Elizabeth Kuon Arce oraz Roberta Samaneza Argumedo oba określenia, lechugillas i maguey, dotyczą dekoracji roślinnej, która także mogła pojawiać się jako
} 
TECHNE

T E X N H

SERIA NOWA

ale nie pozwala na precyzyjne wykończenie ${ }^{95}$, dlatego często wykorzystywano go do wykonywania większych fragmentów rzeźby, jak w przypadku figury św. Franciszka dla klasztoru franciszkanów w Cusco. Zgodnie z umową z 1712 roku rzeźba miała być wykonana $\mathrm{z}$ dwóch materiałów - z drewna cedrowego dłonie i głowa (czyli widoczne fragmenty ciała, wysunięte spod szaty), zaś maguey miał posłużyć do wyrzeźbienia pozostałych części tułowia ${ }^{96}$.

Bardzo ważnym elementem dekoracyjnym ołtarzy procesyjnych były lustra. Widać je na obrazach ukazujących dekoracje w czasie procesji Bożego Ciała, ale mamy także potwierdzenie użycia tego materiału w źródłach archiwalnych. Do ozdoby ołtarza wznoszonego przez Gerónima de Lozadę (1740) miało być wykorzystanych 60 luster $^{97}$, w przypadku kontraktu z 1718 roku czytamy tylko o konieczności dostarczenia dziewięciu luster ${ }^{98}$, natomiast w 1723 roku kontrakt mówi jedynie o lustrach jako dekoracji, bez szczegółowej specyfikacji ${ }^{99}$.

W Cusco także wiele ołtarzy znajdujących się na stałe we wnętrzach świątyń otrzymało dekorację wykonaną z luster. Najsłynniejsze obiekty znajdują się w kościele klarysek, gdzie lustra są zdecydowanie elementami dominującymi w kompozycji, ale możemy je odnaleźć również w innych ołtarzach, jak w retablo de Virgen Dolorosa czy Señor de la Caída w kuzkeńskim kościele la Sagrada Familia ${ }^{100}$ (ilustr. 16) albo w ołtarzu św. Antoniego w kaplicy seminarium pod tym samym wezwaniem.

Tradycja wykorzystania luster jako dekoracji nieobca była też Europie, a szczególnie można jej obecność odnotować w Hiszpanii; jako przykład lustrzanych ornamentów może posłużyć ołtarz Matki Boskiej Różańcowej w kościele El Sagrario w Sewilli ${ }^{101}$ (ilustr. 17). Po raz kolejny warto ponadto wspomnieć, że tradycja dekoracyjna ołtarzy procesyjnych była wspólna dla całego regionu andyjskiego. W relacji z procesji Bożego Ciała z 1720 roku w Potosi odnajdujemy informację o niezwykłym nagromadzeniu luster $\mathrm{w}$ dwóch ołtarzach. W ołtarzu mercedariuszy „wieńcząca kopuła pokryta była pięknymi lustrami w złoconych ramach”, a „po obu stronach

element ozdobny architektury efemerycznej. Jako przykład takiej dekoracji autorzy podają relację Inki Garcilaso de la Vegi dotyczącą wjazdu w 1544 roku wicekróla Blasco Núñeza de Veli do Limy. Kronikarz wspomina łuki triumfalne, które „Indianie wznoszą i [dekorują] wielkim bogactwem kwiatów”; Flores OchoA, Kuon Arce, Samanez Argumedo 2009, s. 156. W moim przekonaniu, wysnutym na podstawie analizy wielu kontraktów (nie tylko związanych z powstawaniem architektury efemerycznej), szczególnie w przypadku określenia maguey mowa jest zdecydowanie o materiale, a nie dekoracji roślinnej skomponowanej ze świeżych roślin.

95 Bruquetas 2017, s. 92.

96 Cornejo Bouroncle 1960, s. 266.

97 ARC, Sección Notarial, Ambrosio Arias de Lira (25), f. 224 r.

98 Tamże, Sección Notarial, Mathias Ortega Ximenez (313), f. 121 r.

99 Tamże, Sección Notarial, Mathias Ortega Ximenez (318), f. 90 v.

100 Ołtarze prezentują ogromne nagromadzenie luster. W każdym z nich znajduje się ponad 250 sztuk.

101 Całość ołtarza powstała pod koniec XVII wieku, jednak prezentowana na ilustracji część centralna, arkada z figurą Marki Boskiej Różańcowej, pochodzi z drugiej połowy XVIII wieku; Gómez PiÑol, Gómez GonzÁlez 2004, s. 49. 

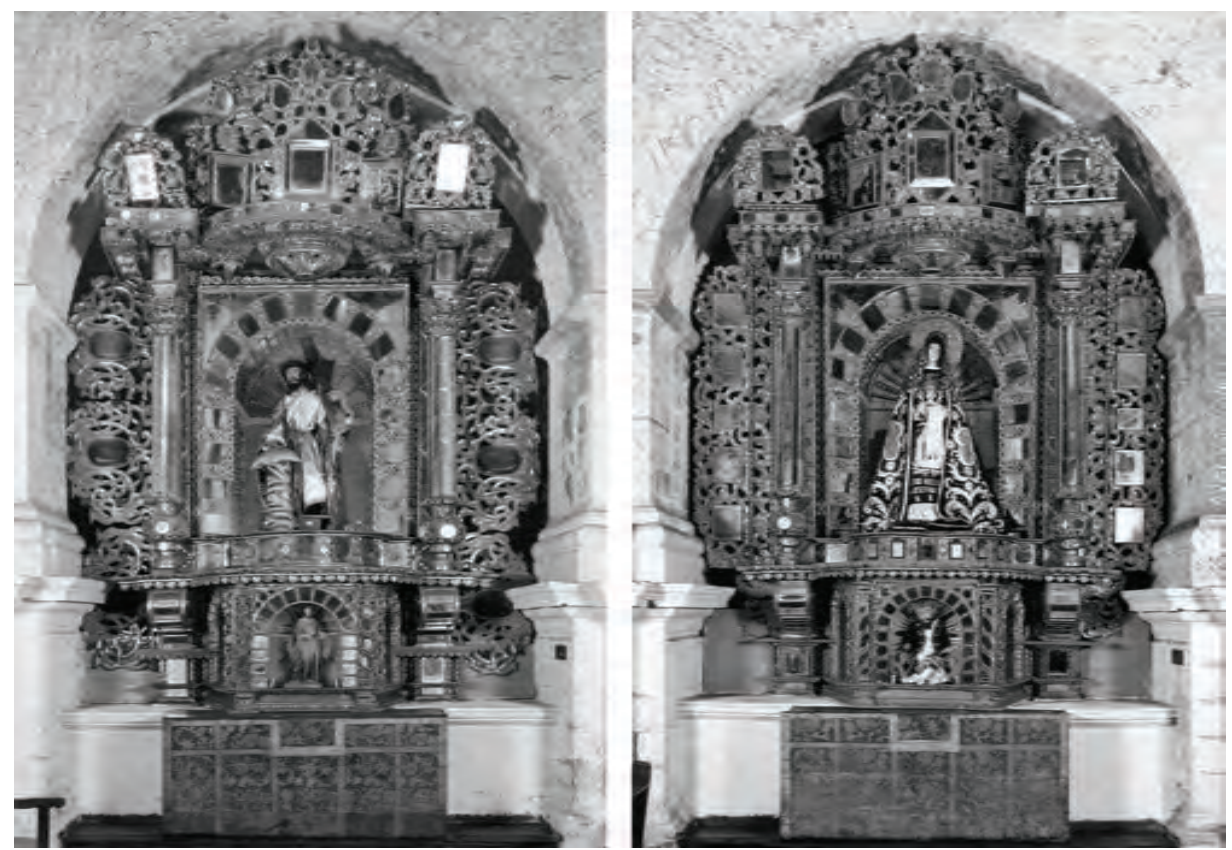

16. Ołtarz Señor de la Caída i ołtarz Virgen Dolorosa, kościół la Sagrada Familia, kompleks katedralny, XVIII wiek, Cusco, Peru, fot. E. Kubiak
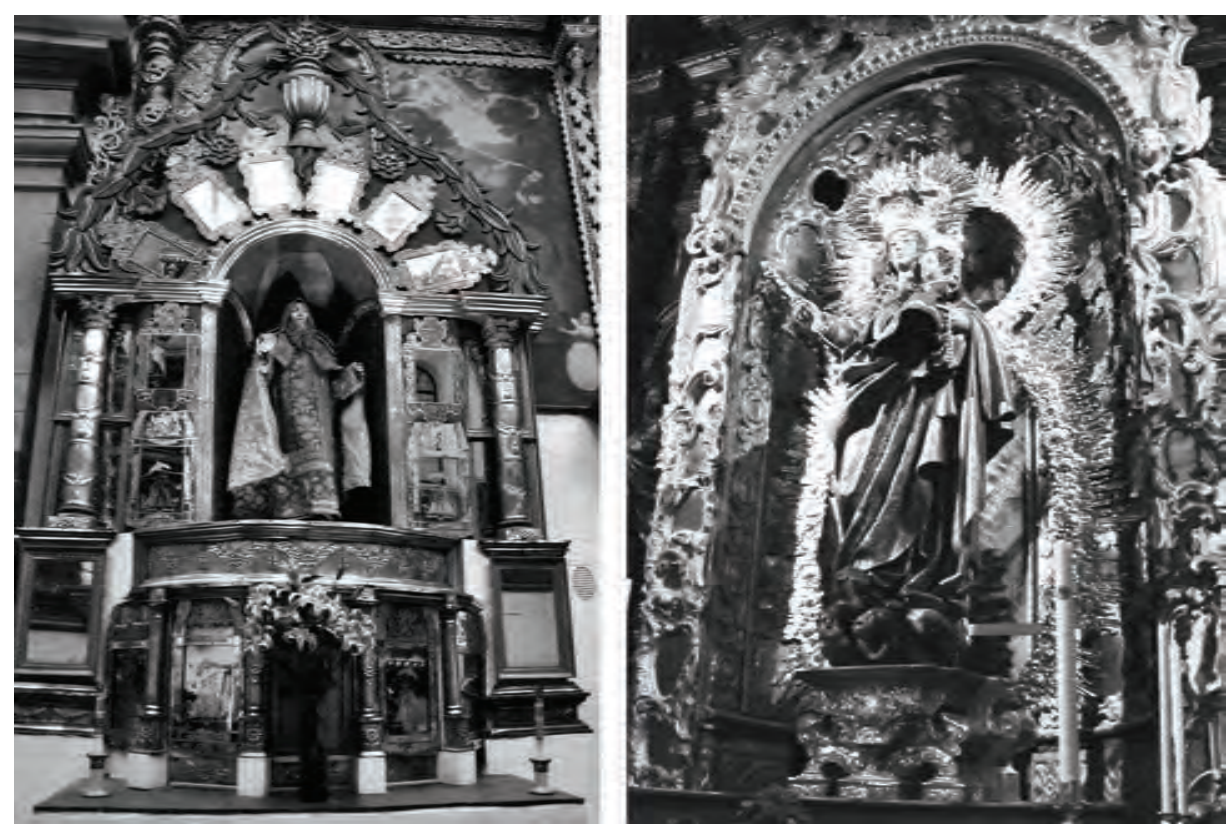

17. Ołtarz San Antonio Abad w kaplicy San Antonio Abad, XVIII w., Cusco, Peru [fot. E. Kubiak 2018], ołtarz Matki Boskiej Różańcowej, kościół El Sagrario, Sewilla, Hiszpania, fot. E. Kubiak 
TECHNE

T E X N H

SERIA NOWA

[znalazło się] wiele luster, których w całym ołtarzu będzie ponad 320 sztuki, dużych, średnich i małych ${ }^{102}$ ", zaś w ołtarzu wzniesionym przez członków zakonu betlemitów ${ }^{103}$ „wszystkie gzymsy, kapitele i postumenty [wykonane zostały] z luster”104.

Materiałem bardzo popularnym, a jednocześnie wyróżniającym barokową architekturę efemeryczną Ameryki Łacińskiej były pióra. Można je zobaczyć na każdym z namalowanych ołtarzy, wymieniane są także w wielu kontraktach ${ }^{105}$. W tym przypadku możemy powiedzieć o wyjątkowym oddziaływaniu dekoracji architektury okazjonalnej na sztukę sakralną. Dekoracje z piór nie mogły oczywiście znaleźć się jako stały element wystroju kościołów, ale zostały dodane jako ornament w malarstwie ściennym, a wiele wykonanych w tej technice portali i ołtarzy utrwalało zwyczaj umieszczania wielobarwnych piór jako nakrycia belkowania czy zwieńczenia w formie bukietów. W samym Cusco bogata dekoracja z piór widoczna jest w malowanym obramowaniu (z motywami architektonicznymi) rzeźbionej postaci tronującego św. Piotra w kaplicy Santo Roma w klasztorze Santa Clara. Pióra wieńczą kapitele kolumn salomonowych flankujących niszę z wizerunkiem, „wyrastają” ze zwornika łuku umieszczonego ponad postacią świętego, a także z malowanych konsolek, na które opada sklepienie kaplicy ${ }^{106}$. W dekoracyjnym fryzie w kaplicy hacjendy Buena Vista (San Jerónimo) powtarzają się motywy dzbanków z kwiatami oraz bukietów wykonanych z piór ${ }^{107}$. Również w okolicach Cusco, w kościołach prowincji, odnajdujemy $\mathrm{w}$ dekoracji malarskiej motywy z piór. $\mathrm{W}$ malowanym portalu prowadzącym do kaplicy pełniącej funkcję baptysterium w kościele w Checacupe (ilustr. 18) pióra pokrywają cały fryz, a także tworzą kompozycje w miejscach kapiteli kolumn. W pierwszym okresie po konkwiście Peru starano się wykorzenić użycie piór, które traktowano jako element wzmacniający indiańskie tradycje i pamięć dawnych wierzeń ${ }^{108}$, mimo to jednak materiał ten nadal stosowano, i - jak

102 La cúpula superior se cubrió con hermosos espejos con marcos dorados, a los lados muchos espejos, que éstos en todo el altar fueron sobre 320 entre grandes, medianos y pequeños. Także dalej wymieniane są elementy lustrzane („krystaliczne lustra” / cristalinos espejos), jak i całe konstrukcje ozdobione lustrami („trzy stopnie złocone bardzo obszerne, ośmiokątne, które pokryte zostały lustrami ze złoconymi ramami" / tres gradas doradas muy espaciosas, ochavadas, que se cubrieron con espejos de marcos dorados); Arzáns Orsúa y Vela 2012, s. 102-103.

103 La Orden de los Hermanos Betlemitas lub la Orden de los Hermanos de Nuestra Señora de Belén. Jest to zakon założony w 1656 roku w Gwatemali przez hiszpańskiego misjonarza Pedra de San José de Betancura jako pierwszy na ziemiach Ameryki. W Limie pierwszy klasztor został założony w 1672 roku, a do Cusco zakonników sprowadził biskup Manuel de Mollinedo y Angulo w 1698 roku; ViñUALES 2004, s. 164.

104 (...) todas las cornisas, capiteles y bancos con espejos; Arzáns Orsúa y Vela 2012, s. 103.

105 W kontraktach na ołtarze procesyjne z lat: 1723, 1740; ARC, Sección Notarial, Mathias Ortega Ximenez (318), f. 90 v.; tamże, Sección Notarial, Ambrosio Arias de Lira (25), f. 224 r.

106 Flores Ochoa, Kuon Arce, Samanez Argumedo 1993, s. 245.

107 Tamże, s. 207.

108 Mujica Pinilla 1996 [1992], s. 289; pióra były ważnymi elementami dekoracji strojów (szczególnie ceremonialnych), a także obiektami składanymi w ofierze; Flores OchOA, KuON Arce, Samanez Argumedo 1993, s. 243. 

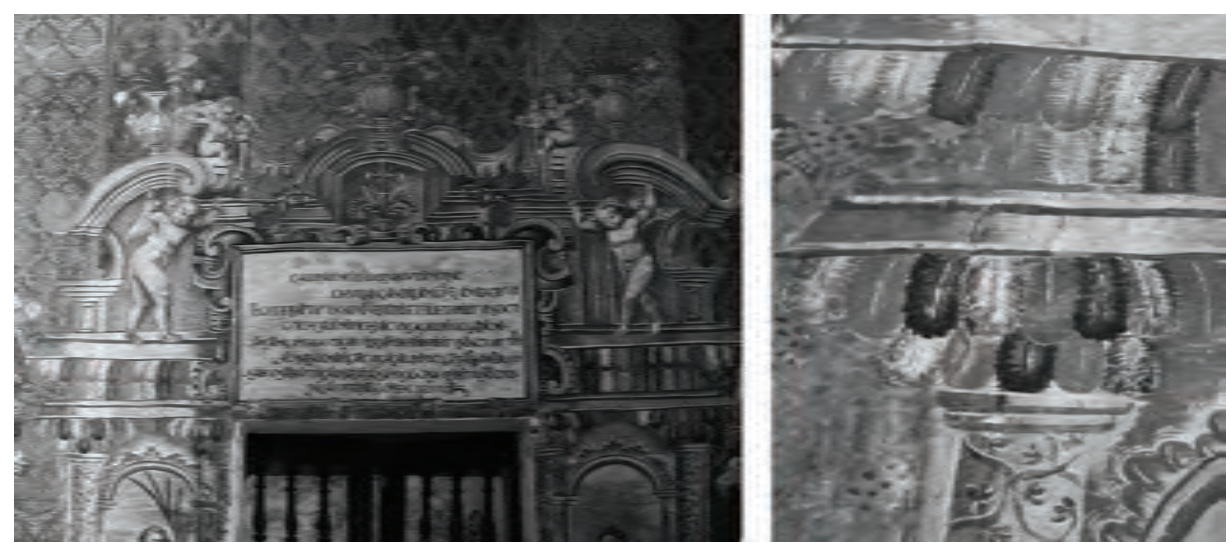

18. Malowany portal, wejście do baptysterium w kościele $w$ Checacupe, malarz nieznany, pierwsza tercja XVII wieku, Checacupe, Peru, fot. E. Kubiak

twierdzi Ramón Mujica Pinilla - można powiedzieć, że został schrystianizowany. Z jednej strony wizerunki Marii, aniołów arkebuzerów czy figurki aniołków na ołtarzach procesyjnych można określić jako „zindianizowane” dzięki dekoracjom z piór przystrajającym ich głowy, z drugiej zaś strony same pióra przeszły transformację znaczeniową. Z czasem trzy kolory piór pojawiające się w pióropuszach wizerunków religijnych (niebieski, zielony i czerwony) były utożsamiane z trzema cnotami teologicznymi (wiara, nadzieja i miłość) ${ }^{109}$. Pióra nadal fascynowały, ale stały się jednocześnie elementem charakteryzującym religijną sztukę regionu andyjskiego.

W kontraktach XVIII-wiecznych wymieniano także inne, bardziej szlachetne materiały, choć nie są one już tak powszechne. Z jednej strony należy to wiązać z ograniczonym użyciem bardziej kosztownych dekoracji, z drugiej zaś z lapidarną formą opisu wielu ołtarzy w umowach zlecających ich wykonanie. Wśród elementów wymienianych w ołtarzu z 1740 roku pojawiają się płyty szylkretowe ${ }^{110}$, natomiast w kontrakcie na wykonanie łuku triumfalnego z 1691 masa perłowa ${ }^{111}$. Użycie droższych materiałów zależne było oczywiście od możliwości finansowych fundatorów. W najbogatszym mieście regionu andyjskiego, Potosi, w opisie ołtarza wzniesionego w czasie procesji Bożego Ciała przez mercedariuszy w 1720 roku wymieniane są nie tylko szylkret czy heban, ale także kość słoniowa ${ }^{112}$.

\section{Programy ikonograficzne ołtarzy}

Programy ideowe ołtarzy procesyjnych łatwiejsze są do odtworzenia na podstawie materiału ikonograficznego niż w oparciu o zachowane kontrakty, gdzie najczęściej brak szczegółowych opisów. Na przedstawieniach ilustrujących kuzkeńską procesję

\footnotetext{
109 Mujica Pinilla 1996 [1992], s. 294.

110 ARC, Sección Notarial, Ambrosio Arias de Lira, (25), f. 224 r.

111 Cornejo Bouroncle 1960, s. 85.

112 ArZÁns Orsúa y Vela 2012, s. 103.
} 
TECHNE

T E X N H

SERIA NOWA

Bożego Ciała w głównych scenach ołtarzowych dominują przedstawienia religijne, co jest oczywiste. Najważniejszym wątkiem ikonograficznym jest Eucharystia, jej ustanowienie podczas Ostatniej Wieczerzy, a następnie adoracja i obrona (defensa). Zdaniem Carolyn Dean program ideowy cyklu malarskiego ukazujący procesję Bożego Ciała należy wiązać z osobą ówczesnego biskupa Manuela de Mollinedo y Angulo. Autorka pisze, że program wszystkich ołtarzy, a także pozostałe wątki ikonograficzne są spójne na wszystkich płótnach i mają ukazywać triumf religii katolickiej w andyjskim mieście charakteryzującym się silnymi tradycjami inkaskimi oraz osobisty udział w tych dokonaniach samego biskupa. Elementem triumfalnym, odnoszącym się zarówno do religii, jak i autora programu ideowego przedstawień, są - zdaniem Dean - wozy procesyjne obecne na niektórych obrazach cyklu (ilustr. 3). Jest to element fikcyjny w realiach kuzkeńskich, konstrukcje takie nie pojawiały się $\mathrm{w}$ czasie procesji. Wiadomo natomiast, że wozy procesyjne z pewnością znane były biskupowi Mollinedo y Angulo, który przybył z Madrytu, gdzie w czasie procesji Bożego Ciała, ale także i innych obchodów religijnych czy świeckich były bardzo popularne. Z drugiej zaś strony obrazy cyklu kuzkeńskiego charakteryzują się sporym realizmem, sportretowane zostały na nich wszystkie grupy społeczne, zilustrowano tam też elementy tradycji inkaskich przejawiające się przede wszystkim w strojach. Maszerujący w katolickiej procesji Inkowie mieli być, zdaniem Dean, świadectwem dokonań biskupa w zakresie ewangelizacji ${ }^{113}$.

Autorka zwraca także uwagę na przedstawienie Dzieciątka Jezus (Niño Jesús) na ołtarzu usytuowanym przed kościołem jezuitów (ilustr. 14). Strój małego Chrystusa jest typowy dla wyobrażeń europejskich, wiadomo jednak, że prezentowany na obrazie wizerunek łączyć należy $\mathrm{z}$ bractwem funkcjonującym w owym czasie w kościele jezuitów i zrzeszającym ludność indiańską. Według relacji opisującej święto beatyfikacji Ignacego Loyoli (1610) rzeźba Chrystusa należąca do tego bractwa została określona jako „Dzieciątko Jezus w stroju Inki”"14. Wiadomo, że Manuel de Mollinedo y Angulo wprowadzał restrykcje w kwestii używania inkaskich insygniów władzy, a także wykorzystywania ich przy dekoracji wizerunków religijnych. Biskup zarządził zdjęcie z głowy dziecięcych wizerunków Chrystusa mascapaichy ${ }^{115}$, a niekiedy również emblematów słonecznych ${ }^{116}$. W Cusco zalecenie to

\footnotetext{
113 DeAn 2002 [1999], s. 90-91; Carolyn Dean zgadza się z hipotezą Teresy Gisbert (1985, s. 243), że najprawdopodobniej za sprawą biskupa Manuela de Mollinedo y Angulo w Cusco pojawiła się publikacja opisująca Święto Matki Boskiej Niepokalanie Poczętej odbywające się w Walencji. Jest ona autorstwa Juana Bautisty Valdy z 1663 roku i zawiera grafiki ukazujące wozy procesyjne. To one bez wątpienia posłużyły jako wzory naśladowane na obrazach serii kuzkeńskiej.

114 Dean 2002 [1999], s. 91; (...) niño Jesus en habito de Inga; pełny opis święta: Relación de la Fiesta 1610 1923, s. 446-454; Relación de la fiesta 1610 2000, s. 156-161.

115 „Mazkha paycha - chwast noszony na opasce na głowie, symbol władzy Zapay Inki”, SzEMIŃSKI, ZıóŁKOWSKI 2006, s. 344.

116 Słońce, czyli Inti, pełniło rolę najważniejszego bóstwa w panteonie Inków, a jego symbolem była tarcza słoneczna. Głównymi świętami w roku ceremonialnym Inków były Intip Raymi (wyznaczone przez przesilenie czerwcowe), Qhapaq Raymi (przesilenie grudniowe) oraz
} 
dotyczyło wizerunku w świątyni parafialnej San Jerónimo oraz figurek znajdujących się w kościołach regionu kuzkeńskiego w Andahuaylillas i Caycay ${ }^{117}$.

Kult samego Dzieciątka Jezus wywodzi się z Europy, na południu Hiszpanii był bardzo rozwinięty, zachowało się tam wiele wizerunków dziecięcego Chrystusa zarówno wykonanych techniką rzeźbiarską ${ }^{118}$ (ilustr. 19), jak i malowanych. Jednak $\mathrm{w}$ andyjskich wizerunkach Niños Inkas można dostrzec element synkretyzmu religijnego, który był charakterystyczny dla silnie zindianizowanych regionów wyżynnych. Pomimo inicjatyw biskupa Mollinedo y Angulo tradycja przedstawień Dzieciątka Jezus jako króla inkaskiego pozostała. Świadczą o tym zachowane XVIII-wieczne obrazy ukazujące dziecięcą postać Chrystusa, który w jednej ręce trzyma krzyż lub glob ziemski, a drugą ma uniesioną w geście błogosławieństwa (co akurat zgodne jest $\mathrm{z}$ ikonografią europejską), przykuwa jednak uwagę nakrycie głowy i mascapaicha opadająca na czoło. Przedstawienie takie określane jest jako Niño Jesús de Huan$c a^{119}$ (ilustr. 20). Obecność tradycji tworzenia i funkcjonowania takich przedstawień potwierdzają również informacje zawarte w dokumentach archiwalnych. Co prawda biskup Mollinedo y Angulo nakazał zdjęcie mascapaichy i emblematu słonecznego z figurki Jezusa w kościele San Jerónimo, jednak w inwentarzu powstałym pomiędzy rokiem 1734 a 1740 czytamy, że wśród innych wizerunków nadal znajduje się „dwoje Dzieciątek, które nazywa się Inkami” ${ }^{120}$.

Przedstawienia takie jak Ostatnia Wieczerza, powtarzające się sceny adoracji Eucharystii, Ukrzyżowania czy też wizerunki samej monstrancji są typowe dla całego świata chrześcijańskiego. Wśród motywów ukazanych w ołtarzach wzniesionych z okazji obchodów Bożego Ciała w moim przekonaniu na uwagę zasługuje kompozycja obronę Eucharystii (ilustr. 21), która jest odmienna od przedstawień

święto oczyszczenia (Zitwa) dedykowane Księżycowi, przypadające w miesiącu Quya Raymi; SZEMIŃsKi, ZıóŁKowsKi 2006, s. 211.

117 CAhill 2000, s. 118; oryginał dokumentu znajduje się w Archivo General de Indias (Sewilla, Hiszpania) (AGI, Audiencia de Lima, Leg. 306). Dokument został niedawno wydany w całości; Vissita Ecesiástica 1687 2008, s. 137-185. Andahuaylillas (...) al Niño Jesús que está en un altar de la iglesia se le quite la mascapaycha y se le pongan o rayos o corona imperial (Vissita Ecesiástica 1687 2008, s. 146); Caycay: (...) Que se quite la mascaypacha al Niño Jesús que está en la iglesia y se le pongan o rayos o corona imperial (Vissita Ecesiástica 1687 2008, s. 150); San Jerónimo: (...) Que se quite al Niño Jesús que está en un altar del cuerpo de la iglesia la mascaypacha y el sol que tiene en el pecho y se le dexen los rayos solamente que están en la cabeça (Vissita Ecesiástica 1687 2008, s. 142). Instrukcje dla kościoła San Jerónimo z 1687 roku zostały również zanotowane w Libro de Fabrica, dotyczyły także usunięcia $\mathrm{z}$ wizerunku Dzieciątka mascapaichy i symbolu słonecznego; (AAC, Fabrica e inventario, Iglesia de San Jerónimo, 1672-1814, f. 26 v.). Na temat kultu Dzieciątka Jezus jako króla Inki w kościele jezuitów w Cusco i w Limie patrz także: MujıCA Pinılla 2016, s. 61-85.

118 Między innymi słynny andaluzyjski artysta Pedro de Mena rzeźbił postacie Niño Jesús triunfante, a także dziecięce wizerunki Jana Chrzciciela; Gila Medina 2018, s. 117-120. Autorem dziecięcych postaci Chrystusa był ponadto Juan Martínes Montañéz, Romero Torres 2009, s. 124-131; BARTOLOMÉ García 2014, s. 27-35. Na temat artystów andaluzyjskich działających w hiszpańskich koloniach Ameryki Łacińskiej patrz: Espinosa SpínOla 2018.

119 Estenssoro Fuchs 2005, s. 137-141.

120 Yt.n dos Niños q[ue] llaman el Ynga, AAC, Colonia, Iglesia de San Jerónimo, sygn. II, 5, 93, f. 1 v. 

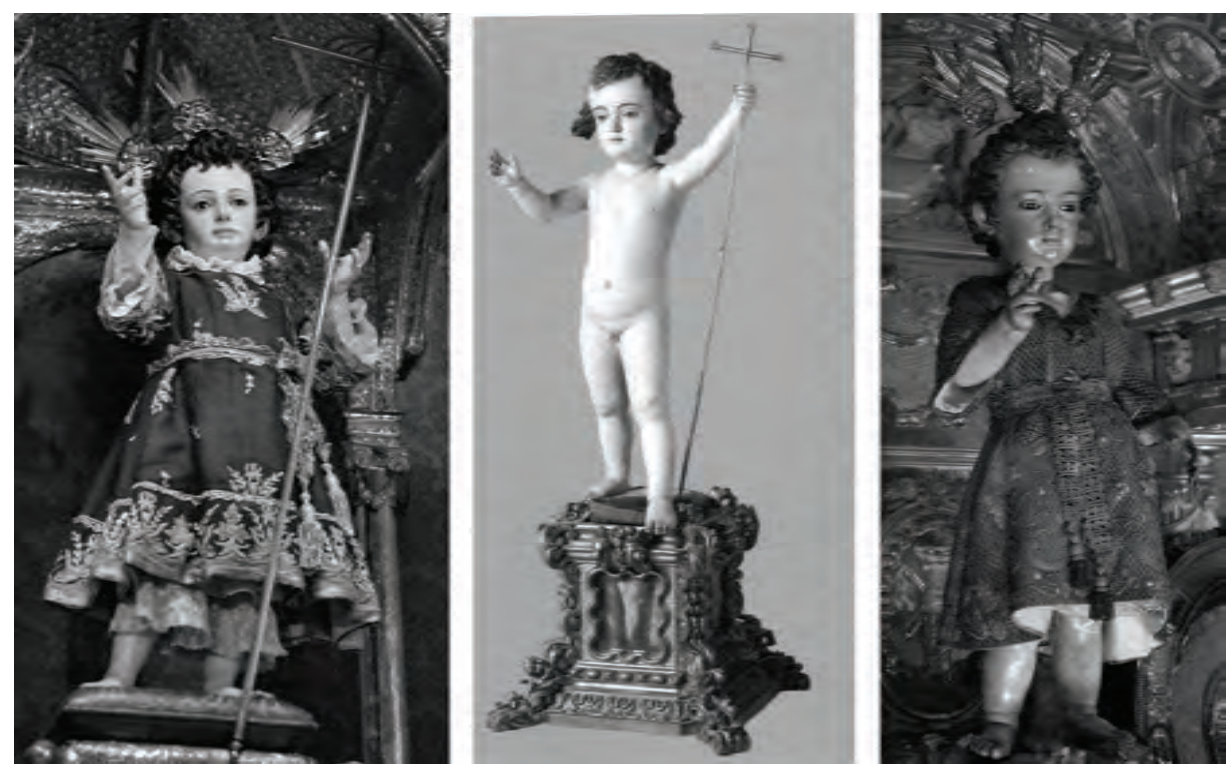

19. Juan Martínez Montañés, Niño Jesús Triunfante, rzeźba drewniana polichromowana, 1606, El Sagrario, Sewilla; Pedro de Mena, Niño Jesús Triunfante, Casa Ajsaris, Granada, ostatnia tercja XVII wieku; Niño Jesús Triunfante, anonim, XVII wiek, kolekcja katedralna w Sewilli; Hiszpania, fot. E. Kubiak
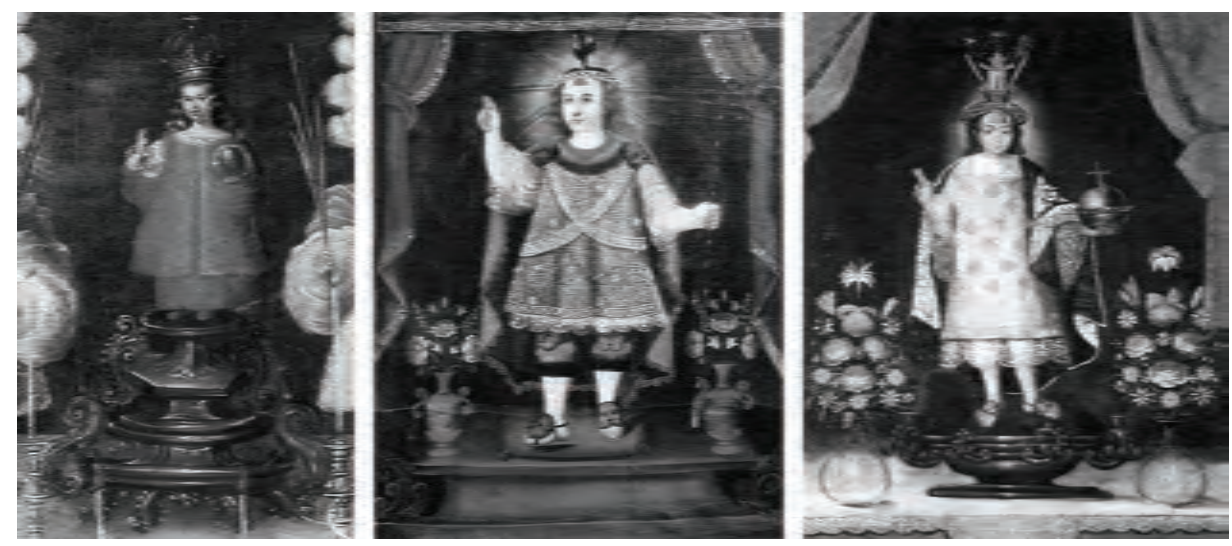

20. Niño Jesús z ołtarza Dzieciątka Jezus, obraz z przedstawieniem zakonu jezuitów, cykl malarski Corpus

Christi, ok. 1675-1680, olej na płótnie, Museo de Arte Religioso, Cusco, Peru, fot. E. Kubiak;

Niño Jesús de Huanca w stroju inkaskim, XVIII wiek, kolekcja prywatna Buenos Aires, Argentyna, fot. Héctor Schenone; Niño Jesús de Huanca w stroju inkaskim XVIII wiek, kolekcja prywatna Lima 

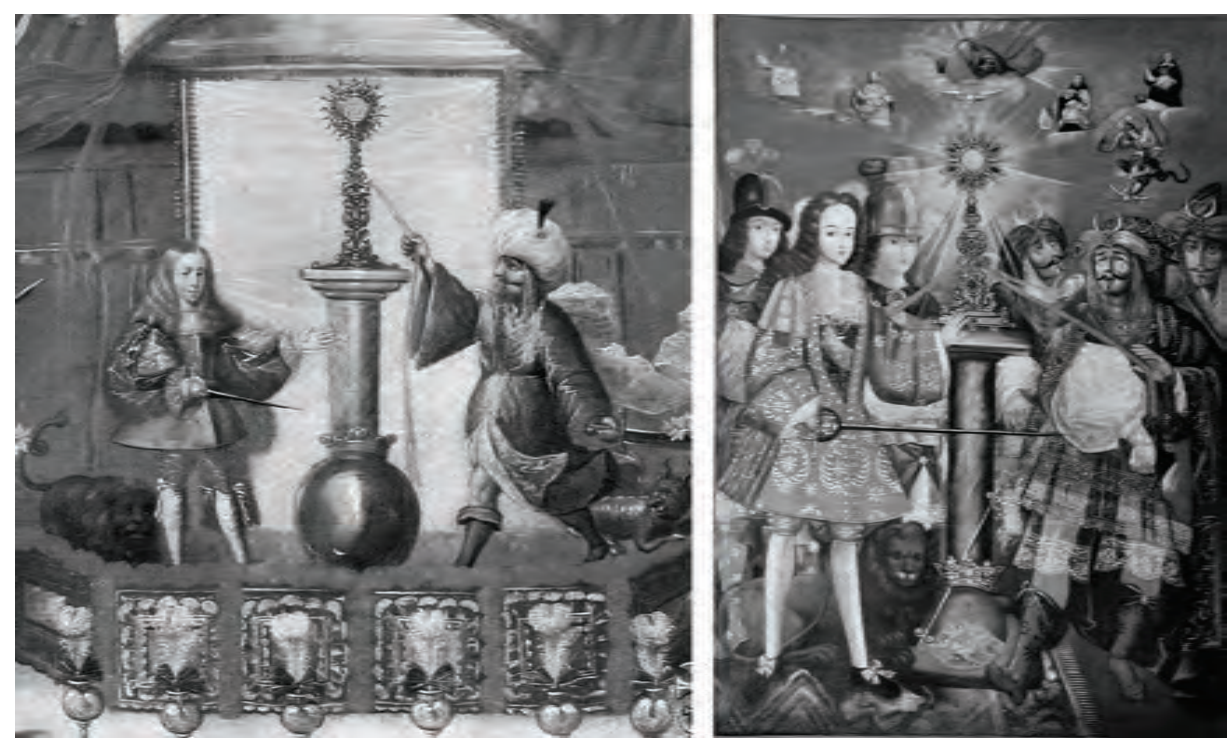

21. Obrona Eucharystii, obraz z przedstawieniem bractw św. Róży z Limy i Matki Boskiej Niepokalanie Poczętej (La Linda), cykl malarski Corpus Christi, ok. 1675-1680, olej na płótnie, Museo de Arte Religioso, Cusco, fot. E. Kubiak 2018; Obrona Eucharystii, obraz anonimowy, XVIII wiek, Centro Cultural Museo San Francisco, La Paz, Boliwia, fot. E. Kubiak

europejskich i charakterystyczna dla sztuki kolonialnej Peru. W kuzkeńskiej scenie $\mathrm{z}$ ołtarza procesyjnego zachowane zostały najważniejsze elementy kompozycji tego typu. Zwykle artyści przestawiający temat obrony Eucharystii odwoływali się do tego samego schematu ikonograficznego - w centrum umieszczano Najświętszy Sakrament, obok broniącego go króla Hiszpanii, a po drugiej stronie niewiernego w orientalizującym stroju próbującego obalić monstrancję. Taki właśnie schemat zastosowano w Cusco. Przedstawienie na kuzkeńskim ołtarzu procesyjnym znów nie było jednostkowe. W 1720 roku podczas procesji Bożego Ciała w Potosi zakon mercedariuszy wzniósł ołtarz z podobnym przedstawieniem ${ }^{121}$, z centralną sceną obrony Eucharystii umieszczoną pod główną kopułą:

(...) a tam monstrancja Pańska, po prawej stronie wizerunek władcy Filipa V, niech Bóg $[\mathrm{Go}]$ zachowa (w bogatym stroju i ozdobami z bardzo kosztownymi kamieniami, ze szpadą w prawej ręce i rezerwuarum monstrancji w lewej jako broniącego wiary), po prawej, po przeciwnej stronie Turek (także w ozdobach i z drogimi kamieniami, które w wizerunkach tych dwóch książąt wyglądają na [wartość] większą niż 100,000 pesos za precjoza) ${ }^{122}$.

121 Mujica Pinilla 2000, s. 282.

122 (...) y allí la custodia del Señor, al lado derecho una imagen del señor Felipe V, que Dios guarde (con rico vestido y joyas de pedrería muy preciosa, con espada en la mano derecha y con la siniestra tomando el viril como defendiendo la fe), al lado izquierdo el turco como opuesto (también arreado de joyas y piedras preciosas, que en las imágenes de estos dos príncipes se veían más de 100,000 pesos de joyas); Arzáns Orsúa y Vela 2012, s. 103. 
Zdaniem Ramóna Mujiki Pinilli kluczowe dla stworzenia takiego schematu ikonograficznego były fragmenty kazania o cechach panegiryku wychwalającego przymioty króla, wygłoszonego przez Juana de Espinosę Medrano w czasie egzekwii Filipa IV odprawianych w katedrze w Cusco ${ }^{123}$. Duchowny wielokrotnie określał władcę Hiszpanii mianem lwa (león austriaco, el austriaco león de España itp.), jednocześnie podkreślając jego zasługi w kwestii propagowania kultu Eucharystii i umocnienia go dla potomnych, a także zapewniania obrony w razie niebezpieczeństwa. Czytamy:

Krótko mówiąc, austriacki lew, w którego ostatnich rykach słyszano tylko polecenie, by sprawowanie kultu Eucharystii kontynowali jego potomkowie; wszystko było nakazem oddawania czci najwielebniejszemu Sakramentowi (...). Wielkim księciem był Filip Czwarty, bez wątpienia ${ }^{124}$.

Dalej autor opisuje też postać króla, który w zbroi, ze szpadą, jest obrońcą religii i Eucharystii. Kończy ten fragment słowami: „Lew jest tym, który z rapierem będzie bronił ołtarza i boskiego stołu"125 - czyli miejsca sprawowania Eucharystii. Oczywiście nie ma pewności, że kazanie to było inspiracją dla kompozycji malarskich prezentujących obronę Eucharystii rozpowszechnionych w andyjskim Peru, faktem jest jednak, że przedstawienia takie powstawały na początku w kręgu sztuki kuzkeńskiej, z czasem zyskując coraz większy zasięg ${ }^{126}$. Na stworzenie nowej ikonografii miały także wpływ grafiki z alegorycznymi wizerunkami Filipa IV, który z uniesioną szpadą broni symbolicznie przedstawionej Eucharystii (monstrancji lub kielicha z Najświętszym Sakramentem). Ilustracja taka znajduje się między innymi w publikacji Martína de Very Instrucción de eclesiásticos, wydanej w Madrycie w 1630 roku $^{127}$ (ilustr. 22). Postać królewska obecna na peruwiańskich obrazach ukazujących obronę Eucharystii koresponduje z epoką powstania przedstawienia. Według José de Mesy i Teresy Gisbert pierwszym władcą broniącym Eucharystii na andyjskich płótnach był Filip IV, a ostatnim Karol IV ${ }^{128}$. Wiele z tych obrazów ma cechy zindywidualizowane, pojawia się w nich ikonografia szczególnie związana z miejscem powstania kompozycji. Obraz, który przywołany został w celu porównania z ołtarzową obroną Eucharystii i stanowi przykład ilustrujący andyjską ikonografię, znajduje się w El Centro Cultural Museo San Francisco w La Paz w Boliwii. Ponad głowami głównych bohaterów widać na niebie Boga Ojca i gołębicę Ducha

\footnotetext{
123 Mujica Pinilla 2000, s. 282.

124 León austriaco, en fin, en cuyos últimos rugidos no se oyó más que encargar el culto de la Eucaristía a su descendencia; todo fue recomendar la veneración del angostísimo Sacramento (...). Príncipe grande fue Filipo Cuarto, no hay que dudarlo; Espinoza Medrano 2011 [1695], s. 283.

125 (...) el León es el que con el estoque defenderá ese altar y esa divina mesa, tamże, s. 285.

126 Mujica Pinilla 2009, s. 1142-1152.

127 Tamże, s. 1145-147; grafika znajduje się w początkowej części książki, strony nienumerowane: VERA 1630

128 Mesa, Gisbert 1982, s. 308.
} 
Świętego (tworzących wraz z znajdującym się poniżej Najświętszym Sakramentem, czyli ciałem Chrystusa, Trójcę Świętą), a także unoszące się na obłokach wizerunki Ojców Kościoła. Najciekawsze jest jednak przedstawienie globu ziemskiego, na którym wsparta została kolumna z umieszczonym w monstrancji Najświętszym Sakramentem. Kulę ziemską ozdobiono widokiem Cerro Rico, wzgórza górującego nad Potosi, które dzięki znajdującym się tam złożom srebra było źródłem bogactwa Hiszpanów ${ }^{129}$ i symbolem górnego Peru (Audiencia de Charcas).

Także portrety władców Hiszpanii były stałym elementem pojawiającym się w dekoracji ulic w czasie świąt i procesji. Oczywiście najbardziej eksponowane były w czasie celebracji związanych z konkretnymi postaciami domu królewskiego, czyli w czasie świąt upamiętniających narodziny i proklamacje, a także podczas egzekwii, jednak również w czasie procesji religijnych istotna była symboliczna obecność króla, bo takie znaczenie możemy przypisywać eksponowaniu portretów królewskich ${ }^{130}$.

Ostatnim typem ikonograficznym, który wydaje się interesujący w dekoracjach okazjonalnych miasta podczas procesji Bożego Ciała, są kompozycje pejzażowe. Choć są to przedstawienia świeckie, umieszczano je zarówno na ołtarzach, wśród obrazów stanowiących tło dla okazjonalnych konstrukcji ołtarzowych, jak i na łukach triumfalnych wznoszonych w czasie świąt religijnych (ilustr. 23). Zwykle były to widoki, krajobraz z dominantą w postaci drzewa na pierwszym planie, nisko umieszczonym horyzontem, wzgórzami i ruinami, z wykorzystaniem perspektywy powietrznej, w których dalszy plan i znaczną odległość zaznaczono niebieską barwą. Jest to o tyle ciekawe, że w malarstwie kuzkeńskim zdecydowanie dominują tematy o charakterze religijnym, a obrazów o tematyce świeckiej pozostało niewiele, wśród nich zdecydowanie prym wiodą portrety. Znamy nieliczne przykłady pejzaży i kompozycji mitologicznych, kilka z nich się zachowało, zaś o istnieniu kilku kolejnych dowiadujemy się ze wzmianek w dokumentach archiwalnych. Informacje te

129 Inne przedstawienia patrz także: Mujica Pinilla 2002, s. 281-283; oraz na temat przedstawień eucharystycznych w malarstwie kolonialnego Peru: Kubiak 2011, s. 213-242; oraz związki ikonografii eucharystycznej z ikonografią monarchii hiszpańskiej: MujICA PINILla 2009, s. $1098-1167$.

130 W tym miejscu możemy przypomnieć koncepcję „podwójnego ciała króla” opisaną przez Ernsta Kantorowicza (1957). Autor odnosi się w swoim tekście do ogólnie przyjętej anglosaskiej tradycji powstałej w średniowieczu. Zgodnie z tą tradycją król posiada dwa ciała. Pierwsze jest ciałem naturalnym (body natural), które jest materialne i śmiertelne, jak każdego człowieka. Drugie ciało możemy nazwać ciałem politycznym (body politic), którego nie można ani zobaczyć, ani dotknąć, i ma charakter symboliczny, składa się z polityki i rządów, jest przeznaczone do sprawowania władzy nad ludem i charakteryzuje się ponadczasowym idealnym stanem (KANTOROwicz 2012, s. 41-43). Drugie ciało, dzięki swojemu symbolicznemu charakterowi, może zostać zmultiplikowane i jego obecność może być manifestowana w różnych miejscach jednocześnie poprzez portrety albo pomniki komemoratywne (KubiaK 2014, s. 90; patrz także: Mínguez Cornelles 2016, s. 68-91). Tradycja ta, tak rozbudowana w średniowieczu, ma swoje korzenie w zwyczajach czasów starożytnych okresu Imperium Rzymskiego, kiedy to wizerunki cesarza (portrety, figury, popiersia) rozsyłano do wszystkich prowincji, wszystkich miast całego imperium, gdzie otaczano je kultem podobnym do kultu władcy (KolB 2008, s. 41). Tradycja średniowieczna znalazła także echo w sposobie pojmowania symbolicznej obecności władcy w okresie renesansu i baroku. 
TECHNE

T E X N H

SERIA NOWA

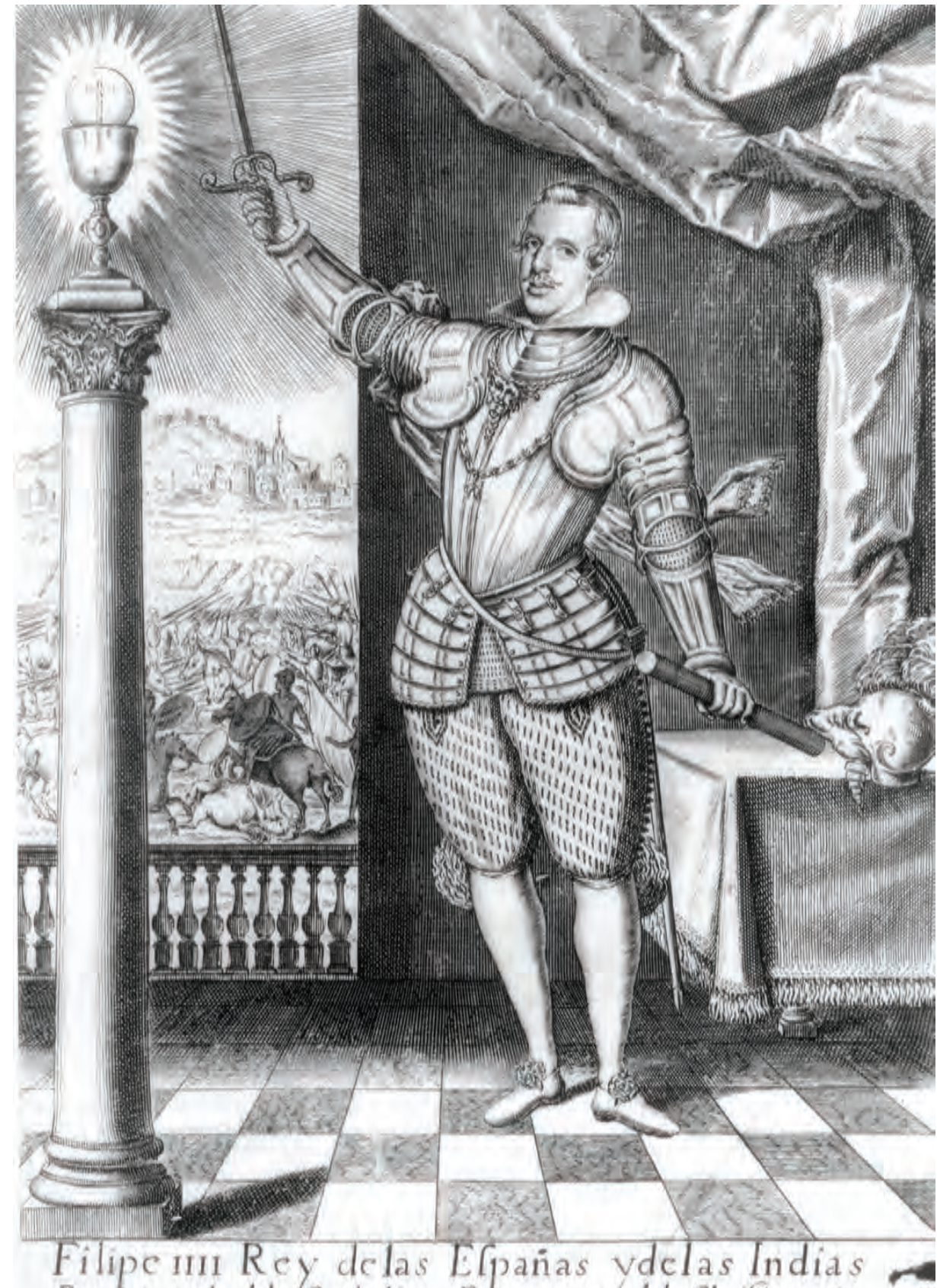

Propugnaculo dela Catbolira Fe, amparo delaChriftiana pie.

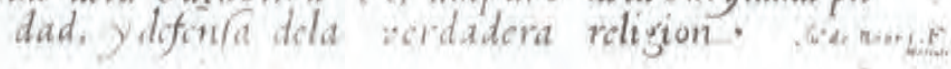

22. Juan de Noort d. Matriti, Portret Filipa IV jako obrońcy religii katolickiej i Najświętszego Sakramentu, Vera 1631, fot. E. Kubiak 

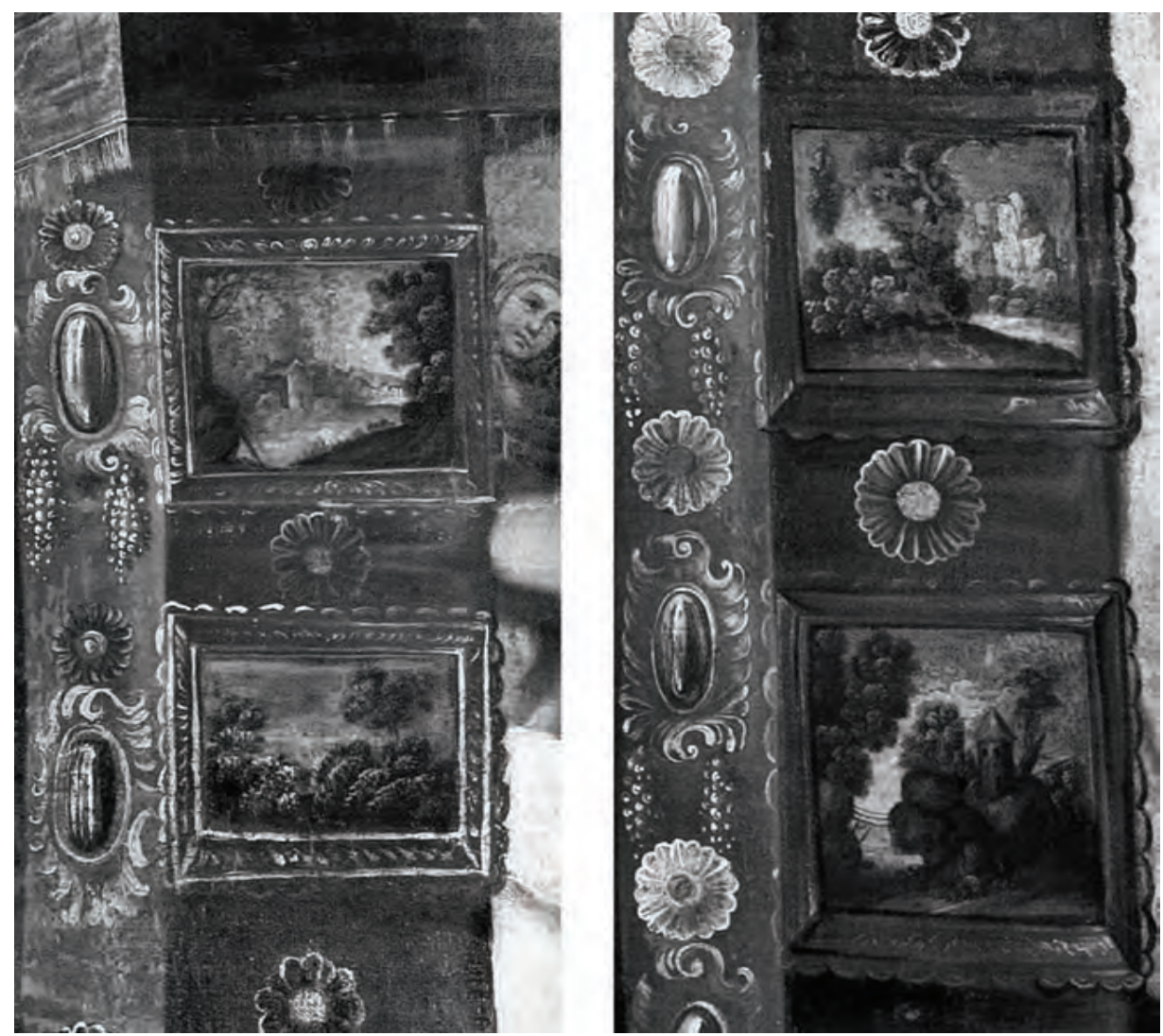

23. Pejzaże, fragmenty dekoracji łuku triumfalnego na obrazie procesji z zakonem mercedariuszy, cykl malarski Corpus Christi, ok. 1675-1680, olej na płótnie, Museo de Arte Religioso, Cusco, Peru fot. E. Kubiak

pochodzą z kontraktów lub testamentów, do których niekiedy dołączano inwentarze dóbr zmarłego. Ramón Gutiérrez, charakteryzując dekoracje wnętrz kuzkeńskich domów kolonialnych, pisze o istnieniu obrazów o świeckiej tematyce i powołuje się między innymi na umowę zawartą pomiędzy Franciso de Suazo y Carabajal i malarzem Carlosem Sánchezem de Mediną i dotyczącą przygotowania obrazów o tematyce mitologicznej. W kontrakcie wymienione zostały tytuły kompozycji: Zniszczenie Troi, Świątynia Diany, Uczta Bogów ${ }^{131}$. Gutiérrez wspomina też, że Antonio de Ochoa Iturmendo deklaruje jako swoją własność sześć „tapiserii do powieszenia z historią Herkulesa"132.

Warto też wspomnieć, że również w innych miastach andyjskich kompozycje pejzażowe czy mitologiczne pojawiały się jako tematy przedstawień towarzyszących świętom kościelnym. W Potosi na ołtarzu wzniesionym przez mercedariuszy

131 GUTiÉRrez 1981, s. 52.

132 (...) tapices de colgar de la Historia de Hércules; ARC, Sección Notarial, Lorenzo Messa Andueza, 1679, cyt. za: GutiérRez 1981, s. 52. 


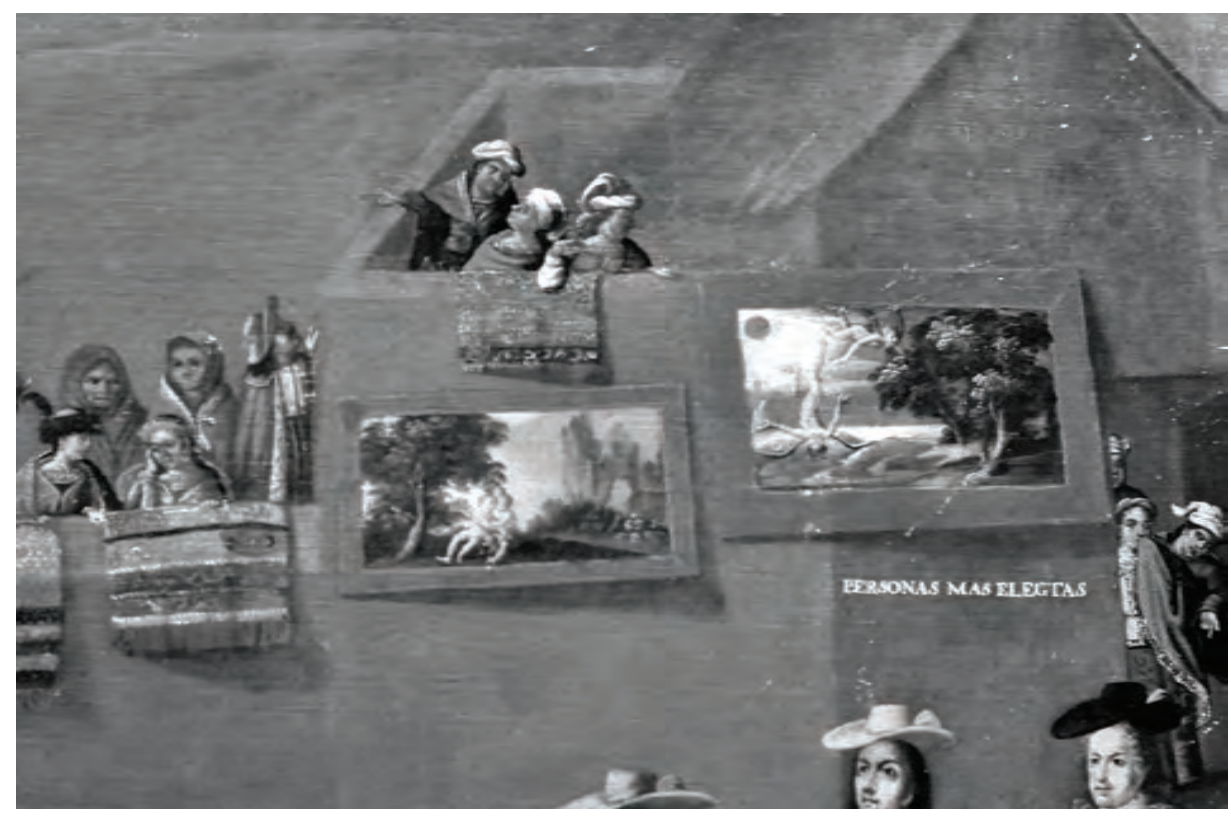

24. Melchor Pérez Holguín, Wjazd Wicekróla Morcillo do Potosi w 1718 roku, 1721, fragment ukazujący dekorację okozajonalną - obrazy z przedstawieniem Erosa i Anterosa oraz Ikara i Dedala, Museo de América, Madryt, Hiszpania, fot. E. Kubiak

w 1720 roku w czasie procesji Bożego Ciała obok wizerunków Chrystusa, Matki Boskiej i świętych znajdowały się także „liczne historie pędzla niderlandzkiego i rzymskiego"133 , być może część z nich miała charakter świecki. Wiemy natomiast, że przedstawienia mitologiczne uświetniały wjazd do Potosi wicekróla Diego Morcillo Rubio de Auñón de Robledo. Uroczystość odbyła się 25 kwietnia 1716 roku i została uwieczniona na obrazie przez Melchora Péreza Holguína w 1718 roku, gdzie widać okazjonalne dekoracje, które odmieniły miasto. Obok bramy triumfalnej ${ }^{134}$, bogatych tkanin i chorągwi, którymi przyozdobiono mury domów i kościołów, można dostrzec obrazy o tematyce mitologicznej i alegorycznej (ilustr. 24). Program został omówiony przez Lucíę Querejazu Escobari, która wśród przedstawień wymienia Ikara i Dedala, Erosa i Anterosa, Merkurego i Argosa, sen Endymiona, Eneasza i Anchizesa oraz Kolosa Rodyjskiego ${ }^{135}$. Niestety tym razem kronikarz Arzáns Orsúa y Vela nie opisał szczegółowo tematyki przedstawień, wspomina tylko, że wśród zawieszonych dekoracji były „obrazy znakomitego pędzla, pejzaże i portrety” ${ }^{\text {”. }}$.

\footnotetext{
133 ArZÁns Orsúa y Vela 2012, vol. 3, s. 103.

134 Bartolomé Arzáns Orsúa y Vela wspomina, że w czasie ingresu ustawiono 2 duże łuki triumfalne oraz 120 małych wykonanych ze srebra; tamże, s. 47-48.

135 Querejazu Escobari 2007, s. 152-154.

136 (...) cuadros de primorosos pinceles, países y retratos; ArZÁns Orsúa y VeLA 2012, vol. 3, s. 49.
} 


\section{Podsumowanie}

Z powodu braku zachowanych źródeł trudno rozstrzygnąć, jak prezentowały się dekoracje okazjonalne z XVI i pierwszej połowy XVII wieku, ale na podstawie późniejszych, dostępnych przekazów można stwierdzić, że ołtarze wznoszone w Cusco w czasie procesji Bożego Ciała miały ustaloną formę. Przeważały kompozycje piramidalne, dekoracje charakteryzowały się przepychem, mając za zadanie uświetnić obchody religijne, ale także stanowiąc element manifestacji bogactwa i przekonań religijnych zarówno pomysłodawców, jak i fundatorów, a być może i samych artystów. Warto zaznaczyć, że obok ołtarzy procesyjnych w czasie Bożego Ciała wznoszono nieustępujące im bogactwem łuki triumfalne (arcos triunfales); jako przykład może posłużyć opis łuku, który miał być wzniesiony na Boże Ciało w 1702 roku. Cech bawełniarzy, jedwabników i pasamoników zlecił wybudowanie łuku „według rysunku, który ma kolumny salomonowe skręcone na czterech podstawach"137. Te, które widać na obrazach kuzkeńskiego cyklu malarskiego Corpus Christi, także prezentują się niezwykle okazale. W czasie procesji Bożego Ciała bardzo istotnym elementem były również andas, o które dbały konfraternie opiekujące się konkretnymi wizerunkami. Bractwa religijne przynależne do parafii i kościołów zakonnych zlecały ich wykonanie lub odnowienie i powtórną dekorację ${ }^{138}$.

Ignacio de Castro pozostawił opis święta celebrowanego w 1787 roku, starając się jak najwierniej oddać jego przepych:

To co można obejrzeć w Cusco w czasie Bożego Ciała, nie ma swojego odpowiednika w Ameryce. Wznosi się na ulicach i placach wystawne Ołtarze, o wyjątkowej konstrukcji, harmonijnej strukturze i dekoracjach manifestujących bogactwo [które się przejawia] w szlachetnych metalach, klejnotach o znacznej wartości, rzadkich drogocennościach. Można zobaczyć czasem chodniki wyłożone prętami ze srebra (...); i rywalizują ci, którzy wznoszą te Ołtarze, by się prześcignąć. Wznoszą też Łuki triumfalne tak samo kosztowne jak Ołtarze; ozdabiają przepięknie ulice, drzwi, balkony, okna i portyki. Wszystkie parafie konkurują Wizerunkami swoich Świętych Patronów niesionych na andas, już to wykonanych z prawdziwego srebra albo po mistrzowsku rzeźbionych i złoconych, dekorowanych sztucznymi kwiatami ze złota, srebra i jedwabiu ${ }^{139}$.

\footnotetext{
137 Cornejo Bouroncle 1960: 257; (...) conforme el dibujo que tiene con las columnas salomónicas torcidas de quatro pies, ARC, Sección Notarial, Francisco Maldonado (207), f. 176 r.

${ }_{138}$ I tak kontrakty na prace artystyczno-rzemieślnicze przy andas zawarly: Cofradía de Nuestra Señora de Gracia założona w klasztorze San Agustín (Cornejo Bouroncle 1960, s. 83); Cofradía de Nuestra Señora de las Nieves założona w klasztorze La Merced (tamże, s. 230); Cofradía de Nuestra Señora del Rosario założona w klasztorze Santo Domingo (tamże, s. 256); Cofradía de Santo Cristo (tamże, s. 265).

139 La que se ve en la Fiesta de Corpus no tiene consonante en la America. Se erigen en calles y plazas suntuosisimos Altares, de extraordinaria elevación, de harmoniosa estructura, de ornato en que se ostenta la riqueza en metales preciosas, joyas de mucho precio, alhajas raras. Se ha visto algu-
} 

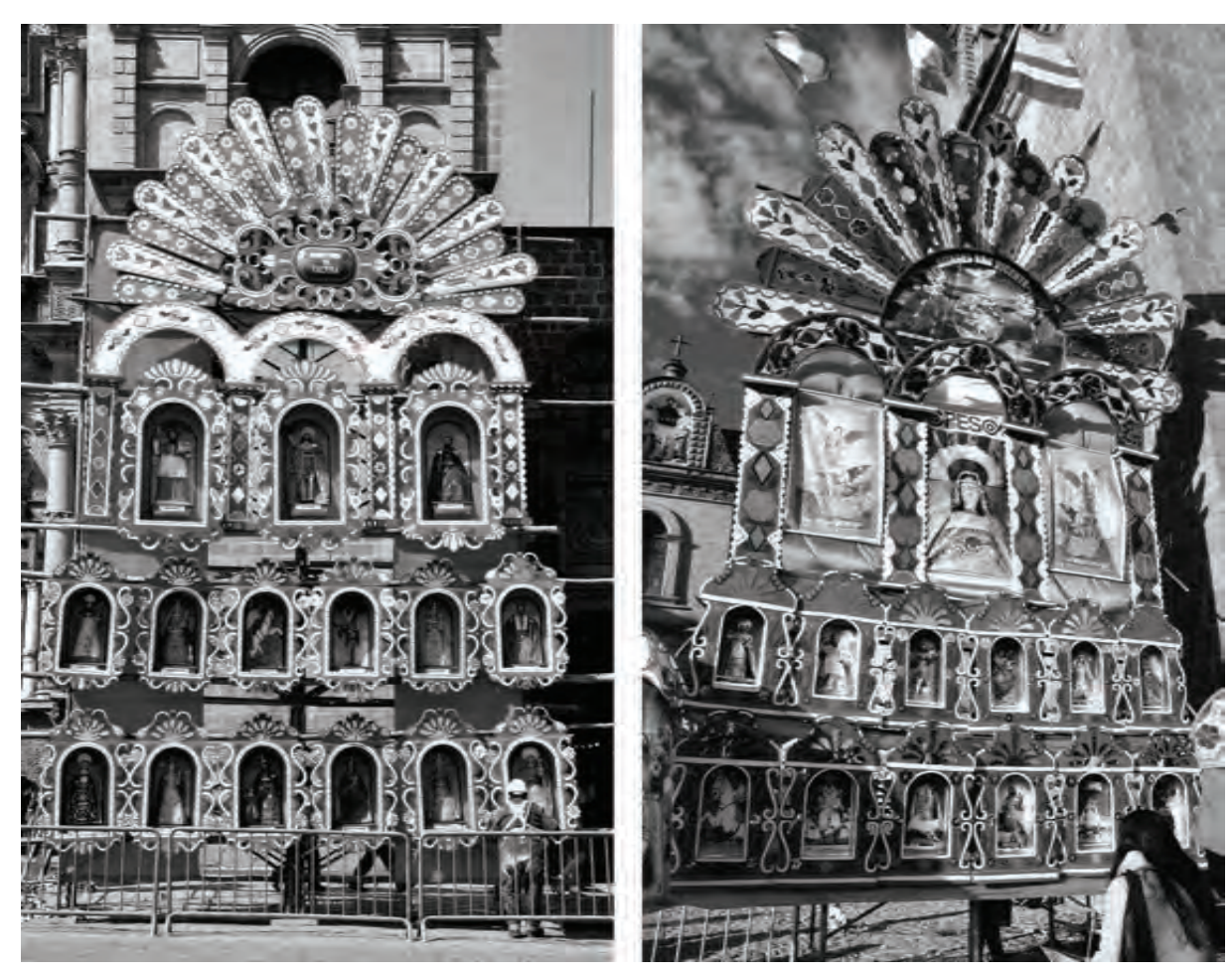

25. Ołtarze procesyjne wzniesione podczas procesji Bożego Ciała w 2013 roku, Cusco, Peru

fot. E. Kubiak

Do dziś w czasie procesji Bożego Ciała wznoszone są ołtarze (ilustr. 25). Wyglądają one inaczej, choć formę niektórych elementów można zestawić z dawnymi kompozycjami ołtarzowymi znanymi z kolonialnego Cusco. Zmienili się także fundatorzy. Prezentowane tutaj ołtarze pochodzą z procesji z 2013 roku, zostały wzniesione przez „bractwa”, ale już o charakterze publicznym. Pierwszy, usytuowany przed kościołem jezuitów, ufundowało Ministerio de Cultura, drugi zaś, ustawiony w sąsiedztwie fasady katedry, powstał w ramach projektu COPESCO - CUSCO (Proyecto Especial Regional Plan COPESCO) podległego Rządowi Regionalnemu w Cusco (Gobierno Regional Cusco).

nas veces enlozado en pavimento de barras de plata (...); y compiten los que fabrican estos Altares; se entapizan con hermosura las calles, puertas, balcones, ventanas, porticos. Todas las Parroquias concurren con las Imágenes de sus Santos Titulares en Andas ya de plata de realze, ya de delicada talladura y dorado, amenizadas con flores artificiales de oro, plata y seda; CASTRO 1978 [1787], s. 57. 


\section{Bibliografia}

\section{Źródła rękopiśmienne}

AAC, Cuenta de Belén (1788-1800) - Archivo Arzobispal del Cusco, Cuenta de razón de entradas y salidas de fábrica de la Iglesia parroquial de Belén, hecha por el fabriquero Isidro Laguna, correspondiente a los años 1788 hasta 1800, sygn. LVI, 3b, 60.

AAC, Cuentas de Cofradía (1788-1800) - Archivo Arzobispal del Cusco, Cuentas de la Cofradía de Nuestra Señora correspondientes a los años 1788-1800, sygn. LVI, 3b, 62.

AAC, Parroquia de los Naturales, Libro de Cabildo (1602-1626) - Archivo Arzobispal del Cusco, Libro de Cabildo y Ayuntamiento de la Parroquia de la Purificación de Hospital de Naturales, 1602-1626.

AAC, Fabrica e inventario, Iglesia de Santa Ana, 1836-1874 - Archivo Arzobispal del Cusco, Fabrica e inventario, Iglesia de Santa Ana, 1836-1874.

AAC, Fabrica e inventario, Iglesia de San Jerónimo, 1672-1814 - Archivo Arzobispal del Cusco, Fabrica e inventario, Libro de de la Fabrica de la yglesia de la Parroquia de San Gerónimo, 1672-1814.

AAC, Colonia, Iglesia de San Jerónimo, sygn. II, 5, 93 - Archivo Arzobispal del Cusco, Memoria y Razon dela Yg[lesi].a deesta Prroquia de S[a].n Gero[ni].mo que hizo el Ill[ustrisi].mo Senor D[octo].r D[o].n Juan de Sarricolea, y Olea deprisiono Obispol dela Gran Ciudad del Cuzco = en esta visita que hisa reconocio la Yg[lesi].a de d[ic] ha parroquia y hallo lo Referido.

AAC, Colonia, Cofradías, 1653-1768, Stma. Vera Cruz - Archivo Arzobispal del Cusco, Colonia, Cofradías, Libro de Cofradía de Santa Cruz en la parroquia San Jerónimo, 1653-1768.

AAC, Colonia, Cofradías, 1661-1768, S. Jerónimo - Archivo Arzobispal del Cusco, Colonia, Cofradías, Libro de Cofradía de San Jerónimo en la parroquia San Jerónimo, 1661-1768.

AGNP, Fondo: Temp. (Inventarios), Caja 1, Legajo 13 (1767) - Archivo General de la Nación (Perú), Lima, Temp. (Inventarios), Caja 1, Legajo 13 (1767), Testimonio de los autos y diligencia que se siguieron para ocupar el colegio de la Transfiguración de que los PP de la Compañía de Jesús, e inventarios que entonces hicieron de los muebles y enseres del dicho Colegio altares y ornamentos de su Iglesia, $68 \mathrm{ff}$.

AGI, Audiencia de Lima, Leg. 306 - Archivo General de Indias, Audiencia de Lima, Legajo 306, Resumen de la vissita eclesiástica que hiso de los beneficios curados que hay en las provincias de Quispicancha, Paucartambo, Calca y Lares, marquesado de Oropesa y parte de la de Abancay, pertenecientes al obispado del Cuzco. Año de 1687.

ANCh, Fondo Jesuitas, sygn. 347 - Archivo Nacional de Chile (Santiago de Chile), Fondo Jesuitas, sygn. 347, Inventario de la capilla y cofradía de Nuestra Señora de Loreto, y otras, ff. 263 r.-273 v.

ARC, Intendencia, Real Hacienda, Legajo 171 - Archivo Regional del Cusco, Intendencia, Real Hacienda, Legajo 171, Expediente Relativo a que no se disparen fuegos artificiales quarto quadras en contorno de donde existen los almacenes de Polbora, y los que hubiese de haber en otras Partes hayan de ser precisamente presidida diligencia de este Gobierno (1785).

ARC, Sección Notarial, Gregorio Serrano Basquez (62) - Archivo Regional del Cusco, Sección Notarial, Escribano Gregorio Serrano Basquez, Protocolo núm. 62, El contrato entre Salvador Sanchez con Francisco Muñoz (1.03.1712), f. 92 v.-93 r.

ARC, Sección Notarial, Amrosio Arias de Lira (25) - Archivo Regional del Cusco, Sección Notarial, Escribano Amrosio Arias de Lira, Protocolo núm. 25, El concierto entre Gerónimo de Lozada con P. Lanilla, A. Flores, R. Aspilcueta (16.03.1739), f. 36 v.-f. 37 r.; El concierto entre Gerónimo de Lozada con diputados del comercio (20.03.1740), f. 224 r.-225 v. 
ARC, Sección Notarial, Francisco Maldonado (207) - Archivo Regional del Cusco, Sección Notarial, Escribano Francisco Maldonado, Protocolo núm. 207, Con..$^{\text {to }}$ entre Joseph de Ochoa con Pedro de Vidauere y otros (18.05.1702), f. 176 r.-176 v.

ARC, Sección Notarial, Mathias Ortega Ximenez (313) - Archivo Regional del Cusco, Sección Notarial, Escribano Mathias Ortega Ximenez, Protocolo núm. 313, El concierto entre gremios $y$ Juan de Becerra (30.04.1718), f. 121 r.-121 v.

ARC, Sección Notarial, Mathias Ortega Ximenez (318) - Archivo Regional del Cusco, Sección Notarial, Escribano Mathias Ortega Ximenez, Protocolo núm. 318, El concierto entre Juan de Becerra con Manuel Sanchez Jurado, Matias Palomino, Francisco Tamaran y Juan Flores (06.04.1723), f. 90 v.-f. 91 r.

ARC, Sección Notarial, Agustin de Aguila Morillas, (18) - Archivo Regional del Cusco, Sección Notarial, Escribano Agustin de Aguila Morillas, Protocolo núm. 18, El concierto entre Juan de Becerra con bachillero Nicolas y Solis presbitero (28.01.1721), f. 207 r.-f. 207 v.

\section{Źródła drukowane i słowniki}

Arzáns Orsúa y Vela 2012 [1965] - Bartolomé Arzáns de Orsúa y Vela, Historia de La Villa Imperial de Potosí, wyd. Lewis Hankey, Gunnar Mendoza, vol. 1-3, Rhode Island 2012 [1965].

Blanco 1974 [1834] - José María Blanco, Diario del viaje del presidente Orbegoso al sur del Peru, wyd. Félix Denegri Luna, Lima 1974.

Carrió de la Vendera 1985 [1775] - Alonso Carrió de la Vendera, El Lazarillo de ciegos caminantes, wyd. Antonio Lorente Medina, Barcelona 1985.

Castro 1978 [1787] - Ignacio de Castro, Relación del Cuzco, wyd. Carlos Danie, Valcárcel, Lima 1978.

Drae 2018 - Diccionario de la lengua española (Real Academia Española), Edición del Tricentenario, dostęp online: https://dle.rae.es/?w=diccionario [data dostępu: 24.01.2019].

Espinoza Medrano 2011 [1695] - Juan Espinoza Medrano, Sermón a las exequias de Don Felipe Cuarto, Rey de las Españas, nuestro señor. Año 1666, [w:] Juan de Espinosa Medrano, La Novena Maravilla, wyd. Luis Jaime Cisneros, José A. Rodríguez Garrido, Lima 2011, s. 281-287.

Esquivel y Navia 1980 [c. 1749] - Diego de Esquivel y Navia, Noticias cronológicas de la gran ciudad del Cuzco, wyd. Félix Denegri Luna, Lima 1980.

Garcilaso de la Vega 1944 [1617] - Inca Garcilaso de la Vega, Historia General del Perú, vol. 3, Buenos Aires 1944.

Procesión 1692, 2000 - Procesión de Nuestra Señora de Loreto, 1692, [w:] Peter T. Bradley, David Cahill, Habsburg Peru. Images, Imagination and Memory, Liverpool 2000, s. 161-162.

Relación de la Fiesta 1610, 1923 - Relación de la Fiesta, 1610, [w:] Festividades del tiempo heroico del Cuzco, wyd. Carlos A. Romero, „Inca”, vol. 1, nr 2 (1923), s. 447-454.

Relación de la fiesta 1610, 2000 - Relación de la Fiesta, 1610, [w:] Peter T. Bradley, David Cahill, Habsburg Peru. Images, Imagination and Memory, Liverpool 2000, s. 156-161.

SANTANDER 1748 - José Antonio Santander, La lealtad satisfecha, el jubilo ensalzado, y gratos reconocimientos de la fidelidad conque expresso su sentimiento la... Ciudad del Cuzco en las Exequias del S.D. Phelipe V, Lima: en la Imprenta que está en la Plazuela del pie del Cerro, 1748.

Toledo 1924 - Francisco de Toledo, Libro de visita general del virrey don Francisco de Toledo, 1570-1575, wyd. Carlos A. Romero, „Revista Histórica”, 7(2) (1924), s. 113-216.

Vissita Eclesiástica 1687, 2008 - Resumen de la vissita eclesiástica que hiso de los beneficios curados que hay en las provincias de Quispicancha, Paucartambo, Calca y Lares, marquesado de Oropesa y parte de la de Abancay, pertenecientes al obispado del Cuzco. Año de 1687, [w:] Pedro Guibovich Prez, Luis Eduardo Wuffarden, Sociedad y gobierno episcopal: las visitas del obispo Manuel Mollinedo y Angulo (Cuzco 1674-1694), Lima 2008, s. 137-184. 
Vera 1630 - Martín de la Vera, Instrucion de Eclesiasticos preuia i necessaria. Al buen uso y practica de las Çeremonias mui util y prouechosa a Eclesiasticos y seglares para saber como ande orar j adorar a Dios en lo diuino j onrrar a los ombres en lo politico. Dedicala j consagrala con todo acatamiento a la piedad del no menos pio qye Catolico Monarca D. Filipe IIII N. S. ${ }^{r}$ Rei de las Españas y de las Indias, Madrid 1630.

\section{Opracowania}

Amado Gonzales 2017 - Donato Amado Gonzales, El estandarte real y la masacaypacha. Historia de una institución inca colonial, Lima 2017.

BAKER 2008 - Geoffrey Baker, Imposing Harmony. Music and Society in colonial Cuzco, DurhamLondon 2008.

BARtolomé García 2014 - Fernando R. Bartolomé García, Un niño Jesús del círculo de Martínez Montañés en Vitoria, „BIBLID”, 4 (2014), s. 27-35.

Bernales Ballesteros 1987 - Jorge Bernales Ballesteros, Historia del arte hispanamericano, vol. 2: Siglos XVI a XVII, Madrid 1987.

Bernales Ballesteros 1996 - Jorge Bernales Ballesteros, El Corpus Christi: fiesta barroca en Cuzco, Sevilla 1996.

Bonet Correa 1990 - Antonio Bonet Correa, Fiesta, poder y arquitetcura. Aproximaciones al barroco español, Madrid 1990.

Bonet Correa 1993 - Antonio Bonet Correa, La arquitectura efímera del barroco en España, „Norba: revista de arte”, 13 (1993), s. 23-70.

Bottineau 1968 - Yves Bottinaeu, Architecture Ephémère et Baroque Espagnol, „Gazette des Beaux-Arts", LXXI (1), s. 213-230.

Brachetti 2005 - Ángela Brachetti, El año en fiestas. La convivencia con los dioses en los Andes del Perú, Madrid 2005.

Brachetti-Tschohl 2014 - Ángela Brachetti-Tschol, Pachamama, los apus y los „dioses de los blancos". Un ciclo anual festivo de los Andes del Perú, Madrid 2014.

BRUQuetas 2017 - Rocío Bruquetas, Un conjunto de esculturas de maguey de la iglesia de San Miguel de Mamara en el Apurímac andino, [w:] Escultura ligera, wyd. Rosa $\mathrm{M}^{\mathrm{a}}$ Román Garrido, Valencia 2017, s. 85-98.

Buelna Serrano 2002 - María Elvira, Corpus Christi en México, [w:] La fiesta del Corpus Christi, wyd. Gerardo Fernández Juárez, Fernando Martínez Gil, Cuenca 2002, s. 285-298.

CAHILl 2000 - David Cahill, The Inca and Inca Symbolism in Popular Festive Culture: The Religious Processions of Seventeenth-Century Cuzco, [w:] Peter T. Bradley, David Cahill, Habsburg Peru. Images, Imagination and Memory, Liverpool 2000, s. 87-150.

Chacón Pumacahua 2015 - Jennifer Chacón Pumacahua, Tesoro del Templo de Nuestra Señora de Belén - Cusco, Cusco 2015.

Cornejo Bouroncle 1960 - Jorge Cornejo Bouroncle, Derroteros de arte cuzqueño, Cuzco 1960.

Dean 2002 [1999] - Carolyn Dean, Los cuerpos de los incas y el cuerpo de Cristo. El Corpus Christi en el Cuzco Colonial, Lima 2002 [1999].

Espinosa Spínola 2018 - Gloria Espinosa Spínola, Artistas andaluces en Hispanoamérica. Siglos XVI-XVIII, Granada 2018.

Estenssoro Fuchs 2005 - Juan Carlos Estenssoro Fuchs, Construyendo la memoria: la figura del inca y el reino del Perú, de la conquista a Túpac Amaru II, [w:] Los incas, reyes del Perú, wyd. Thomas Cummins, Lima 2005, s. 93-173.

Flores Ochoa/Kuon Arce/Samanez Argumedo 2009 - Jorge Flores Ochoa, Elizabeth Kuon Arce, Roberto Samanez Argumedo, Cuzco el lenguaje de la fiesta, Lima 2009. 
Flores Ochoa/Kuon Arce/Samanez Argumedo 1993 - Jorge Flores Ochoa, Elizabeth Kuon Arce, Roberto Samanez Argumedo, Pintura mural en el Sur Andino, Lima 1993.

García 1922 - José Uriel García, La ciudad de los Incas, Cuzco 1922.

Gila Medina 2018 - Lázaro Gil Medina, Pedro de Mena: precisiones y novedades, [w:] El triunfo del barroco en la escultura andaluza e hispanoamericana, wyd. Lázaro Gila Medina, Francisco J. Herrera García, Granada 2018, s. 71-134.

Gisbert 1983 - Teresa Gisbert, Los Angeles de Calamarca, La Paz 1985.

Gómez Piñol/Gómez González 2004 - Emilio Gómez Piñol, Ma Isabel Gómez González, El Sagrario de la Santa Iglesia Catedral de Sevilla, Sevilla 2004.

Gutiérrez 1981 - La casa cusqueña, wyd. R. Ramón, 1981, Resistencia: Departamento de Historia de la Arquitectura, Universidad Nacional del Nordeste.

Hidalgo Nuchera 2012 - Patricio Hidalgo Nuchera, La economía colonial, [w:] Historia de América, wyd. Juan B. Amores Carredano, Barcelona 2012, s. 451-528.

Jouve Martín 2014 - José R. Jouve Martín, The City of the Pheonix: Earthquakes, Royal Obsequies, end Urban Rivalries in Mid-Eighteenth Centuries, [w:] The Transatlantic Hispanic Baroque. Complex Identities in the Atlantic World, wyd. Herald E. Braun, Jesús Prez-Magallón, Farnham 2014, s. 219-235.

Kantorowicz 2012 - Ernst Kantorowicz, Los dos cuerpos del rey. Un estudio de teología política medieval, tłum. Susana Aikini Araluce, Madrid 2012.

Kolb 2008 - Frank Kolb, Ideał późnoantycznego władcy, tłum. Anna Gierlińska, Poznań 2001.

Kuвінк 2011 - Ewa Kubiak, Alegoria Eucharystii - wspólne wzory graficzne w malarstwie XVII i XVIII w. w Polsce i w Peru, „Arte de America Latina”, 1 (2011), s. 213-242.

Кивінк 2014 - Ewa Kubiak, La pintura de batalla en el Virreinato del Perú: Victorias de Carlos Ven el Museo de la Casa de Moneda en Potosí (Bolivia), „Itinerarios. Revista de estudios lingüísticos, literarios históricos y antropológicos”, vol. 19 (2014), s. 75-94.

Kuвінк 2015 - Ewa Kubiak, Reinterprestacje. Percepcja i recepcja dziel architektury na przykładzie światyń jezuickich Ameryki Południowej okresu kolonialnego, Łódź 2015.

Kubiaк 2019 - Ewa Kubiak, Las exequias reales de Felipe V en Cusco (1747) y el arte, „Revista del Museo Nacional", Tomo 52, Nº1 (2019), Mueso Nacional de la Cultura Peruana, Lima (w druku).

LABARGa GARCía 2005 - Fermín Labarga García, La piedad popular en América hasya finales del siglo XVIII, [w:] Teología en América Latina, Vol. 2/1: Escolastica barroca. Ilustración y prepatación de la Independencia (1665-1810), wyd. Josep-Ignasi Saranyana, Carmén-José Alejos Grau, Madrid-Frankfurt am Main 2005, s. 787-865.

Lleo Cañal 1975 - Vicente Lleo Cañal, Arte y espectaculo: la fiesta del Corpus Christi en la Sevilla de los siglos XVI y XVII, Sevilla 1975.

Mariátegui Oliva 1951 - Ricardo Mariátegui Oliva, Pintura cuzqueña del siglo XVII. Los maravillosos lienzos del Corpus existentes en la iglesia de Santa Ana del Cuzco, Lima 1951.

Mariátegui Oliva 1954 - Ricardo Mariátegui Oliva, Pintura cuzqueña del siglo XVII en Chile. Los valiosos lienzos del Corpus cuzqueño de propiedad de D. Carlos Peña Otaequi en Santiago, Lima 1954.

MARIÁtegui Oliva 1983 - Ricardo Mariátegui Oliva, Nuevo lienzo auténtico del Corpus cuzqueño. Un falso lienzo; más consideraciones acerca de los maravillosos cuadros del siglo XVII, Lima 1983.

Mesa/Gisbert 1982 - José de Mesa, Teresa Gisbert, Historia de la pintura cuzqueña, Lima 1982.

Mesa/Gisbert 2012 [1965] - José de Mesa, Teresa Gisbert, Noticias de arte en la obra de Bartlolomé Arzáns de Orsúa y Vela, [w:] Bartolomé Arzáns de Orsúa y Vela, Historia de La Villa Imperial de Potosí, wyd. Lewis Hankey, Gunnar Mendoza, vol. 3, Rhode Island 2012 [1965], s. 439-460.

Mínguez Cornelles 2003 - Víctor Mínguez Cornelles, Efímero mestizo, [w:] Iberoamérica mestiza. Encuentro de pueblos y culturas, wyd. Miguel León-Portilla, Madrid-México 2003, s. 49-65. 
Mínguez Cornelles 2016 - Víctor Minguez Cornelles, Los dos cuerpos de Carlos II, „Libros de la Corte.es.Monográfico" 4, año 8, s. 68-91.

Moreno Cuadro 1985 - Fernando Moreno Cuadro, Artistas y mentores de barroco efímero, Córdoba 1985 .

Moreno Cuadro 1989 - Fernando Moreno Cuadro, Arquitectura efímera del siglo XVII español, Córdoba 1989.

Mujica Pinilla 1996 [1992] - Ramón Mujica Pinilla, Ángeles apócrifos en la América virreinal, Lima 1996.

Mujica Pinilla 2002 - Ramón Mujica Pinilla, El arte y los sermones, [w:] El Barraco Peruano, Lima 2002, s. 219-313.

Mujica Pinilla 2009 - Ramón Mujica Pinilla, España eucarística y sus reinos. El Santísimo Sacramento como celto y tópico iconográfico de la monarquía, [w:] Pintura de los reinos. Identidades compartidas. Territorio del Mundo Hispánico, siglos XVI-XVIII, wyd. J. Gutiérrez Haces, vol. IV, Mexico 2009, s. 1098-1167.

Mujica Pinilla 2016 - Ramón Mujica Pinilla, El „Niño Jesús Inca” y los jesuitas en el Cusco Virreinal, [w:] Ramón Mujica Pinilla, La imagen transgredida. Ensayos de iconografía Peruana y sus políticas de representación simbólica, Lima 2016, s. 61-85.

QUerejazu Escobari 2007 - Lucía Querejazu Escobari, El programa emblemático alegórico en la entrada del Virrey Morcillo a Potosí en 1716, [w:] La Fiesta. Memoria del IV Encuentro Internacional sobre Barroco, wyd. Norma Campos Vera, La Paz 2007, s. 149-154.

Pérez Sánchez 2005 [1992] - Alfonso E. Pérez Sánachez, Pintura barroca en España 1600-1750, Madrid 2005.

Pietraszczyк-Sęкоwska 2015 - Joanna Pietraszczyk-Sękowska, Tradycje oporu w Andach. Mobilizacje indiańskochłopskie w Peru od XVI do XX wieku, Łódź 2015.

Ramos Sosa 1992 - Rafael Ramos Sosa, Arte festivo en Lima virreinal (siglos XVI - XVII), Juanta de Andalucía 1992.

Rodríguez Romero 2001 - Agustina Rodríguez Romero, Presencia del grabado francés en el Virreinato del Perú. Aportes Iconográficos de Claude Vignon, [w:] Actas del III Congreso Internacional del Barroco Iberoamericano, Sevilla 2001, s. 371-380.

Rodríguez Romero 2012 - Agustina Rodríguez Romero, Vaticinios al óleo. Imágenes de profetas en el Virreinato del Peru, Prohal Monográfico, „Revista del Programa de Historia de América Latina”, vol. 3, primera sección, „Vitral Monográfico”, nr 3 (2012), s. 5-35.

Roel Pineda 1999 - Virgilio Roel Pineda, Historia social y económica de la colonia, Lima.

Romero Torres 2009 - José Luis Romero Torres, Juan Martínez Montañés. 11. The Infant Christ, [w:] The Mystery of Faith. An eye on spanish sculpture, 1550-1750, London 2009, s. 124-131.

RuIz PARdo 2008 - Carmen Ruiz Pardo, La muerte privilegiada. Reales exequias en Lima y Cuzco. Época borbónica, [w:] Arte, poder e identidad en Iberoamérica. De los virreinatos a la construcción nacional, wyd. Inmaculada Rodríguez Moya, Castelló de la Plana 2008, s. 53-70.

Samanez Argumedo 2013 - Roberto Samanez Argumedo, Pintura, escultura y platería, [w:] Tesoros de la Catedral del Cusco, wyd. Teresa Marcos Juez, Carlo Trivelli Ávila, Cusco 2013, s. 79-102.

Sanz Serrano 2007 - María Jesús Sanz Serrano, Jacinto Núñez. Arquitectura efímera para la fiesta de la Inmaculada (1761), [w:] Fiesta y Simulacro, wyd. Rosario Camacho Martínez, Reyes Escalera Pérez, Sevilla 2007, s. 264-265.

SAnZ SERRAno 2008 - María Jesús Sanz Serrano, Fiestas sevillanas de la Inmaculada Concepción en el siglo XVII: el sentido de la celebración y su repercusión exterior, Sevilla 2008.

Szemiński/ZıóŁкоwsкi 2006 - Jan Szemiński, Mariusz Ziółkowski, Mity, rytuały i polityka Inków, Warszawa 2006.

VARgas Ugarte 1947 - Ruben Vargas Ugarte, Ensayo de un diccionario de artífices coloniales de la América Meridional, Buenos Aires 1947. 
ViÑuales 2004 - Graciela María Viñuales, El espacio Urbano en el Cusco Colonial: uso y organización de las estructuras simbólicas, Lima 2004.

Vizuete Mendoza 2002 - J. Carlos Vizuete Mendoza, Teología, liturgia y derecho en el origen de la fiesta del Corpus Christi, [w:] La fiesta del Corpus Christi, wyd. Gerardo Fernández Juárez, Fernando Martínez Gil, Cuenca 2002, s. 17-42.

WUfFARDEN 1996 - Eduardo Wuffarden, La serie del Corpus: historia, pintura y ficción en el Cuzco del siglo XVIII. Notas de los cuadros, [w:] La procesión del Corpus en el Cuzco [katalog wystawy], Sevilla 1996, s. 26-96.

Zaparaín Yáñez 2010 - Maria Jozé Zaparaín Yáñez, Realidad e imagen. Celebraciones festivas en el territorio burgalés, [w:] El arte barroco en el territorio burgalés, wyd. Emilio Jesús Rodríguez Pajares, María Isabel Bringa López, Burgos 2010, s. 329-379. 


\section{Ceremonial Altars Constructed for Corpus Christi processions in the colonial city of Cusco}

$\mathrm{D}$ uring the colonial period, the celebration of secular and religious feasts became a crucial element of socio-religious life in Latin America. Such festivals were one of the tools that facilitated evangelisation. Additionally, it should be remembered that any religious holiday in colonial Peru and Mexico, especially in the areas dominated by the indigenous peoples, constituted a cultural blend of Catholic customs (brought from Europe by the Spanish) and the traditions of native Indian tribes. The feasts celebrated in the $17^{\text {th }}$ and $18^{\text {th }}$ centuries can be divided into one-time and cyclic. The former included beatifications and canonisations, enthronements, proclamations, and exequies, while the recurring celebrations were connected with the liturgical year and particular Marian and Christological devotions, or related to individual saints, thus having a rather local character. This paper focuses on the architecture of procession altars erected in Cusco for the celebrations of Corpus Christi in the colonial period, the first celebration of which, according to Inca Garcilaso de la Vega, took place in 1555. Its procession intended to celebrate the triumph of the new religion brought from Spain, while still observing local traditions. This festival was and still remains one of the most important events of the liturgical year.

Another important event was the incorporation of Corpus Christi into the 1572 Ordinances of Viceroy Toledo for the City of Cuzco (Ordenanzas del virrey Toledo para la ciudad del Cuzco). The most significant source materials facilitating the research on Cusco's ceremonial architecture include paintings of the time, and the preserved archival documentation and chronicles. Among the former, the most useful is the famous series of works portraying a Corpus Christi procession, which are believed to have been painted in the final quarter of the $17^{\text {th }}$ century, at the request of Bishop Manuel de Mollinedo y Angulo. Even though some paintings only show procession figures carried on carts, others present sculptures of saints mounted on andas and carried by cargadores, with altars and triumphal arches in the background.

The most important source documentation includes agreements concluded between benefactors and contractors stored in Archivo Reginal del Cusco. Other helpful materials are the church inventories preserved in the archbishop's archives, church construction logbooks (libros de fabrica) and documents related to confraternities operating at various churches in Cusco, which can be accessed in Archivo Arzobispal del Cusco. Based on these materials, it was possible to conduct an 
analysis of the ceremonial architecture in Cusco, taking into account the following three aspects: the form and the building materials of the researched objects, and their iconography.

The altars erected in Cusco for the purposes of Corpus Christi processions had a predetermined form. The vast majority were pyramidal compositions with lavish ornamentations, whose aim was not only to add splendour to religious celebrations, but also to manifest the wealth and religious piety of the originators, benefactors, and also the artists themselves. Most materials used to construct and decorate procession altars were already known in Europe, including miscellaneous types of fabrics, textiles and expensive silver and tortoiseshell, but occasionally also such typically Andean materials as maguey (ligneous parts of the agave used in sculpting figures) and feathers. The dominating iconographic motif presented in the altars is related to the establishment, worship and triumph of the Blessed Sacrament, with the major representations including the Eucharistic Adoration and the Last Supper, the Crucifixion, the Eucharist, the Defence of the Eucharist, scenes from the Transfiguration of Jesus, and images of the Christ Child. These and other altar representations are based on famous painting compositions popular among the representatives of the Cusco School. 